Development Center

\title{
Evaluation of Sulfide Emissions from a Hydraulic System at the Blue River Dam
}

Victor F. Medina, Michelle Wynter, Carina Jung,

Amber Russell, Timothy Paulus, and Chris S. Griggs

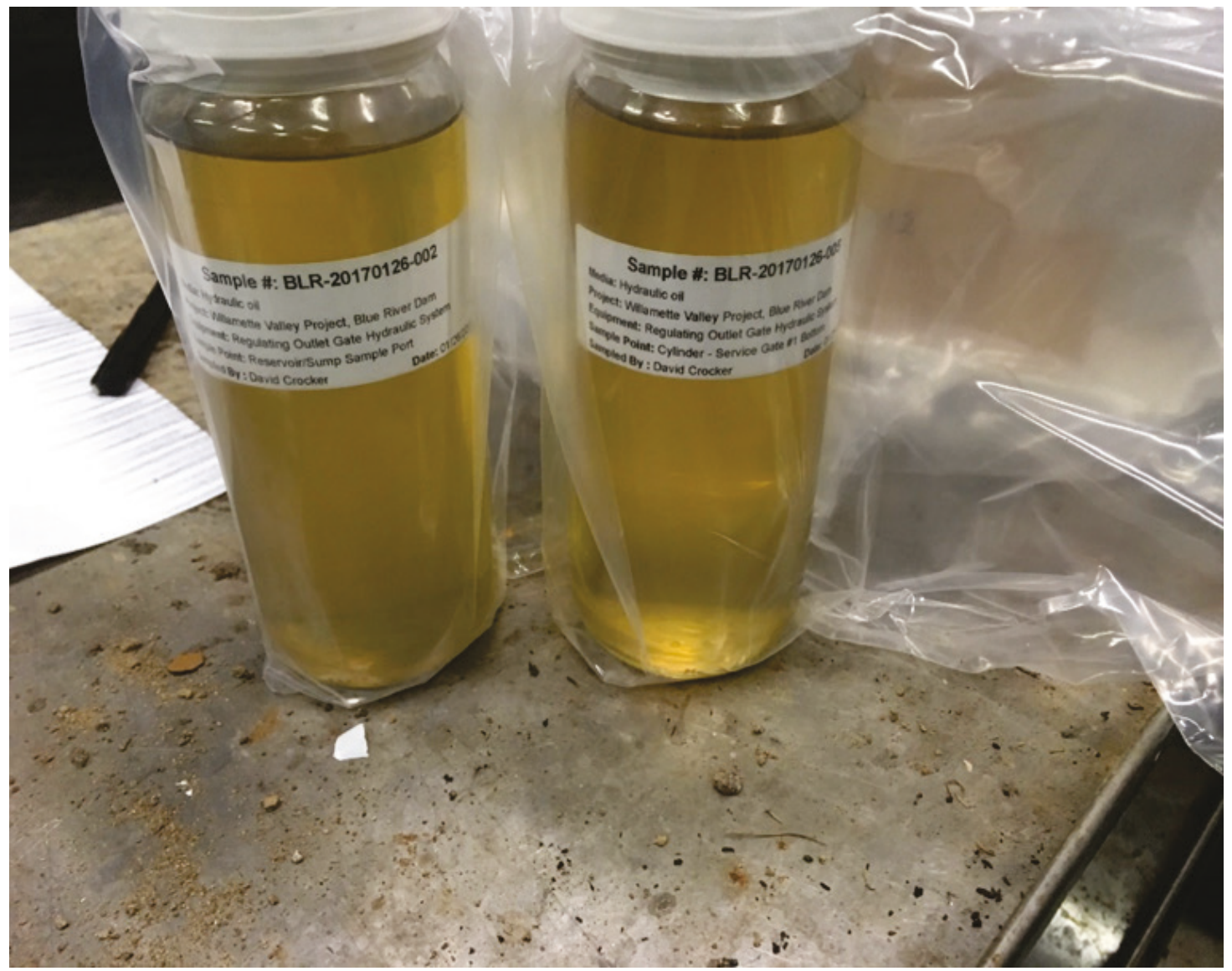


The U.S. Army Engineer Research and Development Center (ERDC) solves the nation's toughest engineering and environmental challenges. ERDC develops innovative solutions in civil and military engineering, geospatial sciences, water resources, and environmental sciences for the Army, the Department of Defense, civilian agencies, and our nation's public good. Find out more at www.erdc.usace.army.mil.

To search for other technical reports published by ERDC, visit the ERDC online library at http://acwc.sdp.sirsi.net/client/default. 


\title{
Evaluation of Sulfide Emissions from a Hydraulic System at the Blue River Dam
}

\author{
and Chris S. Griggs. \\ Environmental Laboratory \\ U.S. Army Engineer Research and Development Center \\ 3909 Halls Ferry Road \\ Vicksburg, MS 39180-6199 \\ Timothy Paulus \\ St. Paul District (MVP) \\ U.S. Army Corps of Engineers \\ $1805^{\text {th }}$ Street East, Suite 700 \\ St. Paul, MN 55101
}

Victor F. Medina, Michelle Wynter, Carina Jung, Amber Russell,

Final report

Approved for public release; distribution is unlimited.

\author{
Prepared for U.S. Army Corps of Engineers \\ Washington, DC 20314-1000 \\ Under Work Unit 33143
}




\section{Abstract}

Hydrogen sulfide releases occurred during a routine maintenance process in a hydraulic oil system at Blue River Dam, Oregon. The project worked under the hypothesis that the sulfide emissions most likely resulted from reductive biological processes. Hydraulic oil samples were collected from the Blue River Dam, and from two other nearby dams with similar hydraulic systems, Hills Creek Dam, and Cougar Dam. Water samples from the reservoir were also collected. Sulfur was found in all the oil and water samples, however, no patterns with sulfur to other parameters (such as percent water or acid neutralization number) were found in the oil samples. A microscopic review of hydraulic filters did not show any evidence of biofilm accumulation. The use of sulfate reductive bacterial genetic probes did not find any microbial activity expected to form sulfide. These results rejected the hypothesis that the sulfide production was from microbial activity. The Authors now hypothesize that the sulfide reaction was from abiotic reactions of an additive, Zinc Dialkyldithiophosphate (ZDDP).

DISCLAIMER: The contents of this report are not to be used for advertising, publication, or promotional purposes. Citation of trade names does not constitute an official endorsement or approval of the use of such commercial products. All product names and trademarks cited are the property of their respective owners. The findings of this report are not to be construed as an official Department of the Army position unless so designated by other authorized documents.

DESTROY THIS REPORT WHEN NO LONGER NEEDED. DO NOT RETURN IT TO THE ORIGINATOR. 


\section{Contents}

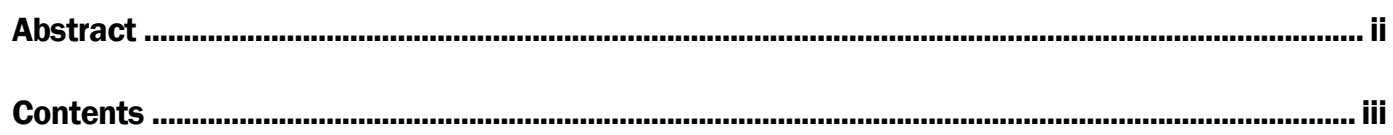

Tables and Figures........................................................................................................................

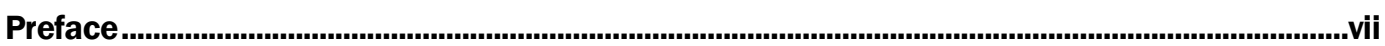

Unit Conversion Factors .................................................................................................................. viii

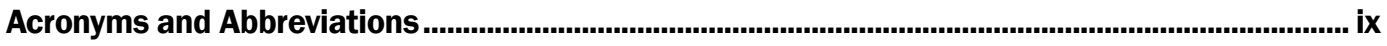

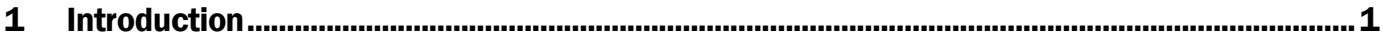

1.1 Purpose of the study....................................................................................... 1

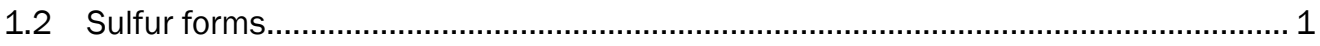

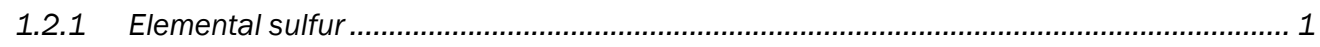

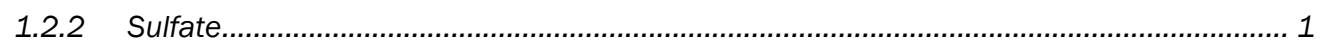

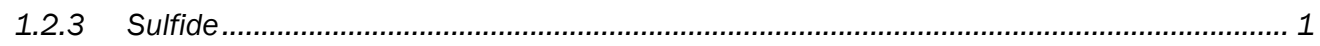

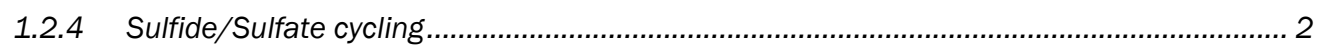

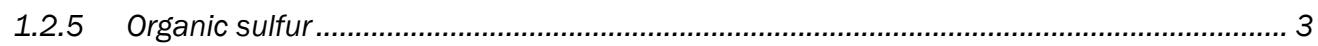

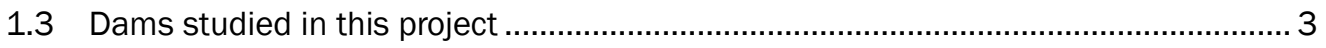

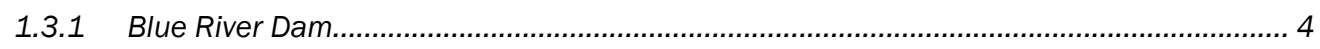

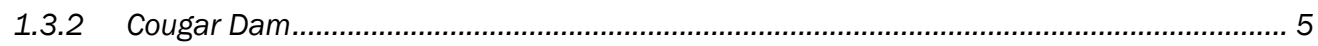

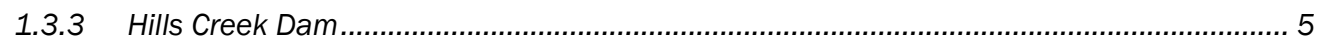

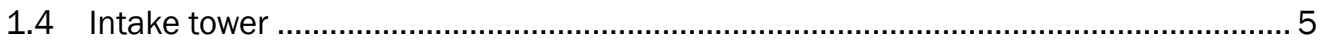

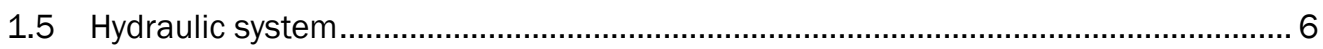

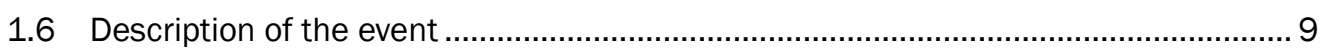

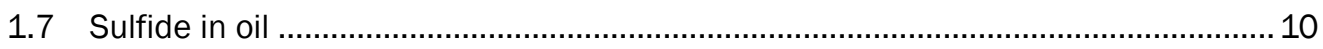

1.8 Hydraulic systems ........................................................................................ 11

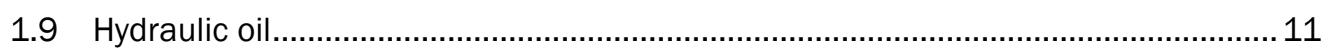

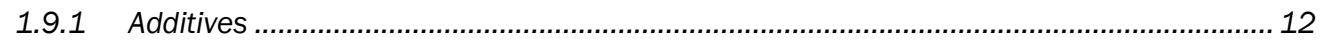

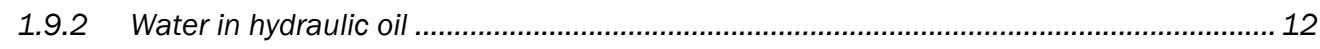

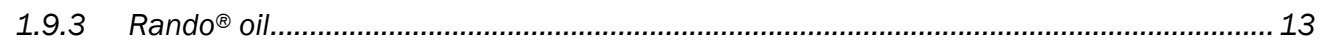

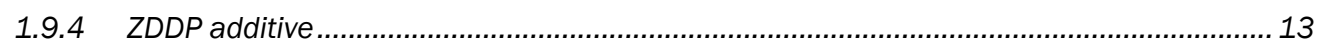

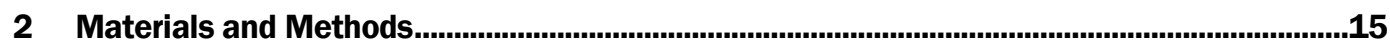

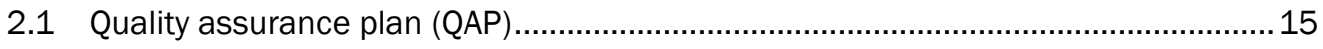

2.2 Samples........................................................................................................ 15

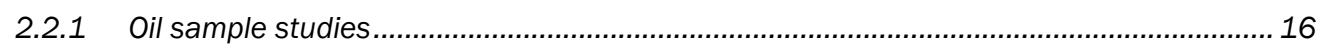

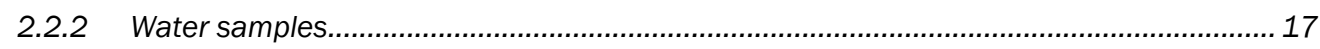

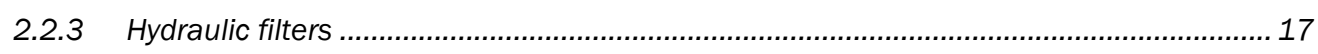

2.2.4 Sulfur reducing microorganisms .......................................................................... 17

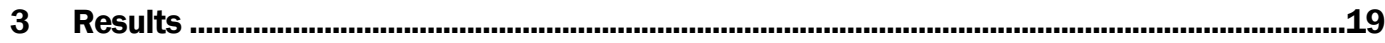

3.1 Chemical analyses ....................................................................................... 19 


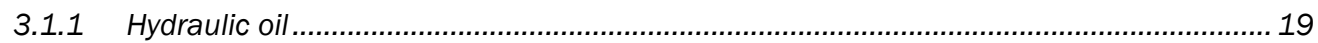

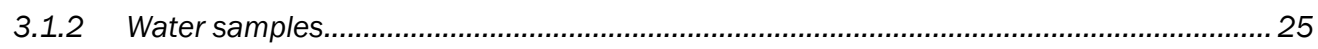

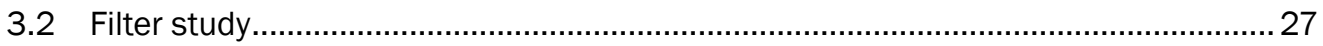

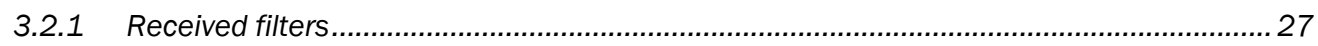

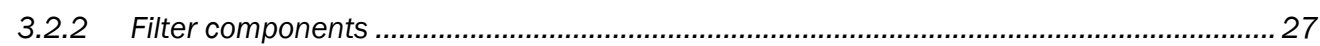

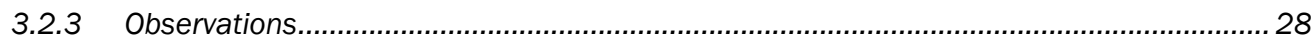

3.3 Genetic probing of hydraulic oil and water samples........................................... 31

4 Discussion ......................................................................................................................................32

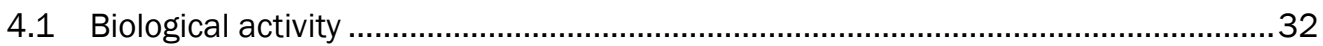

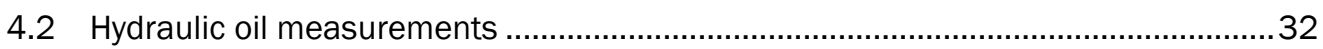

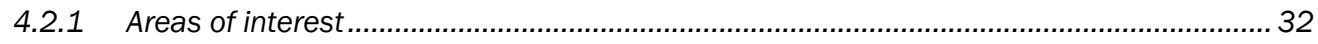

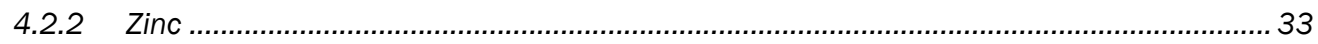

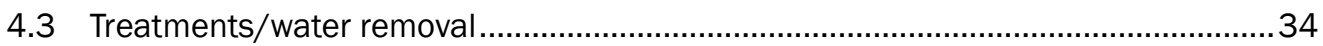

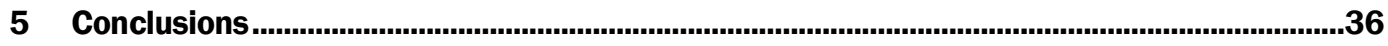

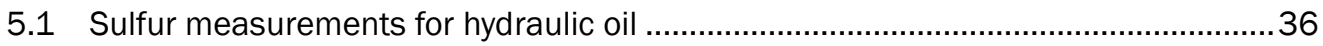

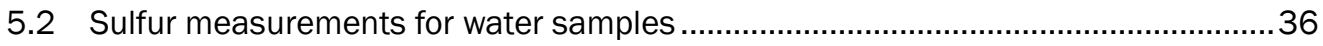

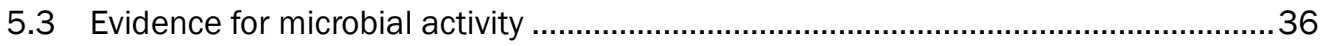

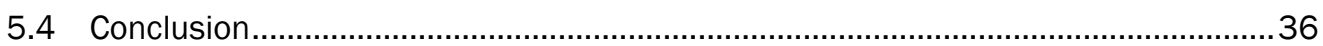

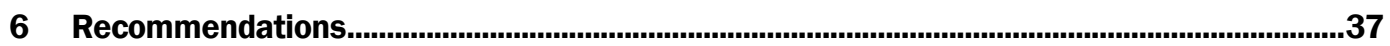

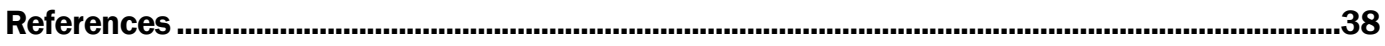

Appendix A: Project Notes (Provided by Catherine Campbell, NWP) .................................................39

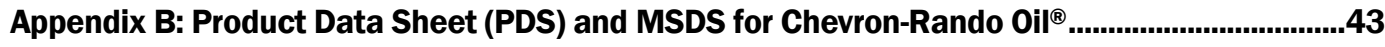

Appendix C: Quality Assurance Plan ........................................................................................55

Appendix D: Report on Sulfur Reducing Microbial Probe Investigation .........................................58

Appendix E: Product Data Sheet (PDS) for Chevron AW Oil - Alternative to Rando Oil. ..............64

Report Documentation Page 


\section{Figures and Tables}

\section{Figures}

Figure 1. The Willamette Valley Project with locations of dams and facilities. Dams in this study are circled in bright red. (base map from USACE, http://www.nwp.usace.army.mil/Locations/Willamette-Valley/)...................................................... 4

Figure 2. Blue River Dam, Oregon.......................................................................................... 4

Figure 3. Schematic of the intake tower (adapted from Crocker 2016).............................................. 6

Figure 4. Schematic of the Blue River Dam regulating outlet hydraulic system. ...............................

Figure 5. Sketch of the Blue River Dam hydraulic system.............................................................. 8

Figure 6. Labelled photograph of the hydraulic fluid system showing key sampling

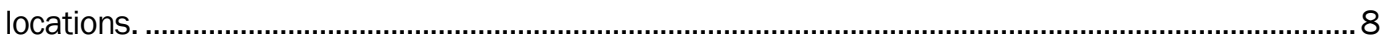

Figure 7. Blue River hydraulic system oil sump temperature gauge. ...............................................

Figure 8. Blue River hydraulic oil system return filter housing.............................................................

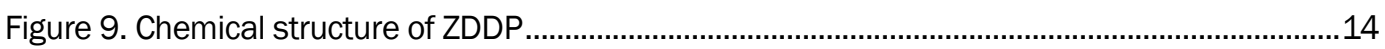

Figure 10. Samples collected for the study. …………….............................................................15

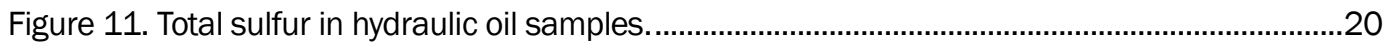

Figure 12. Acid neutralization numbers in hydraulic oil samples...................................................21

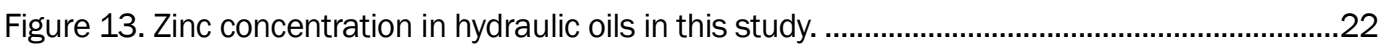

Figure 14. Percent water in oil samples in the study. The high concentrations in the Hills Creek Dam oil samples dominate the graph. The photo inset shows a separate water phase in one of the Hills Creek Dam samples.

Figure 15. Relationship of percent water and sulfur. (Note, Hill Creek Dam data is not included in the graph because it skewed the graph, but it also did not show an obvious relationship).

Figure 16. Relationship of zinc concentration and sulfur. .............................................................24

Figure 17. Relationship of acid neutralization number and sulfur...................................................25

Figure 18. Comparison of sulfur species in water samples. ...........................................................26

Figure 19. One of the hydraulic oil system filters received for the study. .........................................2

Figure 20. The five materials found in the hydraulic oil filter. .........................................................28

Figure 21. Magnified view of Layer 1 (8X). No evidence of biological growth....................................29

Figure 22. Magnified view of layer 2 (25X). No evidence of biological growth. .................................29

Figure 23. Magnified view of Layer 3 (50X). No evidence of biological growth. ................................30

Figure 24. Magnified view of Layer 4 (100X) No evidence of biological growth................................30

Figure 25. Magnified view of Layer 5 (50X). No evidence of biological growth. .................................31

Figure 26. A vacuum dehydration hydraulic oil purification system with sulfide removal (High Purity Northwest Inc., www.highpuritynorthwest.com).

\section{Tables}

Table 1. Hydrogen Sulfide toxicity and explosive characteristics (sources: Nicholson and O'Brien 2001; NIOSH 2005). 
Table 2. Distance from hydraulic oil sump tank vs. symptoms (Adapted from Crocker 2016). ............10

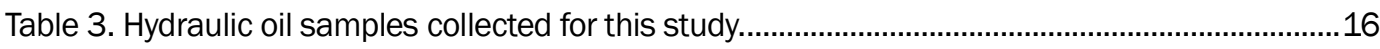

Table 4. Analytes for hydraulic oil samples collected for sulfide study. ............................................17

Table 5. Analytes for water samples collected for sulfide study. ………............................................17

Table 6. Summary of results of hydraulic oil analyses......................................................................19

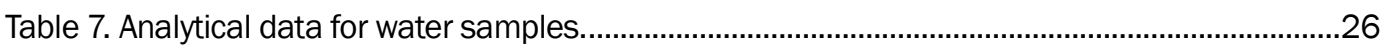

Table 8. Water removal approaches for hydraulic oil (adapted from Kopecky 2004)........................35 


\section{Preface}

This study was conducted by the U.S. Army Engineer Research and Development Center-Environmental Laboratory (ERDC-EL). The project was funded by the Portland District (NWP) under "Work Unit 33143" to support a board of inquiry (BOI) investigating hydrogen sulfide release from a hydraulic oil system at Blue River Dam, Oregon.

At the time of publication, Dr. W. Andy Martin was Chief of the Environmental Engineering Branch, Mr. Warren P. Lorentz was Chief of the Environmental Processes and Engineering Division, and Dr. Elizabeth Fleming was the Director of EL.

COL Bryan S. Green was Commander of ERDC and Dr. David W. Pittman was the Director. 


\section{Unit Conversion Factors}

\begin{tabular}{|l|c|l|}
\hline Multiply & By & To Obtain \\
\hline degrees Fahrenheit & $(F-32) / 1.8$ & degrees Celsius \\
\hline feet & 0.3048 & meters \\
\hline
\end{tabular}




\section{Acronyms and Abbreviations}

\begin{tabular}{|c|c|}
\hline Acronym & Meaning \\
\hline $\mathrm{ACC}$ & American Chemistry Council \\
\hline ASTM & $\begin{array}{l}\text { American Society for Testing and Materials, } \\
\text { International }\end{array}$ \\
\hline BOI & Board of Inquiry \\
\hline BLR & Blue River Dam (Used as a sample identifier) \\
\hline CAS & Chemical Abstract Services \\
\hline CGR & Cougar Dam (Used as a sample identifier) \\
\hline $\mathrm{cm}$ & centimeter \\
\hline DNA & Deoxyribonucleic acid \\
\hline DoD & Department of Defense \\
\hline EL & Environmental Laboratory \\
\hline ERDC & Army Engineer Research and Development Center \\
\hline EPC & Environmental Chemistry Branch \\
\hline EPE & Environmental Engineering Branch \\
\hline FP & Flash Point \\
\hline $\mathrm{g}$ & Gram \\
\hline $\mathrm{g} / \mathrm{L}$ & Grams per Liter \\
\hline HCR & Hills Creek Dam (Used as a sample identifier) \\
\hline HPU & Hydraulic Power Unit \\
\hline IDLH & Immediately Dangerous to Life or Health \\
\hline ISO & International Organization for Standardization \\
\hline $\mathrm{Kg}$ & kilogram \\
\hline $\mathrm{L}$ & liter(s) \\
\hline $\mathrm{LC}_{50}$ & Lethal Concentration 50 \\
\hline LEL & Lower Explosive Limit \\
\hline $\mathrm{mg}$ & milligram \\
\hline
\end{tabular}




$\begin{array}{ll}\text { mL } & \text { milliliter(s) } \\ \text { MSDS } & \text { Material Safety Data Sheet } \\ \text { MW } & \text { Molecular Weight } \\ \text { ng } & \text { nanogram } \\ \text { NIOSH } & \text { National Institute of Occupational Safety and Health } \\ \text { NWP } & \text { Portland District } \\ \text { OSHA } & \text { Occupational Safety and Health Administration } \\ \text { PEL } & \text { Permissible Exposure Limit } \\ \text { PDS } & \text { Product Data Sheet } \\ \text { ppmv } & \text { part per million based on volume (gas concentration) } \\ \text { QAP } & \text { Quality Assurance Plan } \\ \text { REL } & \text { Recommended Exposure Limit } \\ \text { S } & \text { Sulfur } \\ \text { SRB } & \text { Sulfur Reducing Bacteria } \\ \text { STEL } & \text { Short Term Exposure Limit } \\ \text { UEL } & \text { Upper Explosive Limit } \\ \text { USACE } & \text { United States Army Corps of Engineers } \\ \text { USEPA } & \text { United States Environmental Protection Agency } \\ \text { VG } & \text { Viscosity Grade } \\ \text { VI } & \text { Viscosity Index } \\ \text { ZDDP } & \text { Zinc Dialkyl Dithiophosphate } \\ \mu g & \text { microgram } \\ \mu S & \text { microsiemens } \\ & \end{array}$




\section{Introduction}

\subsection{Purpose of the study}

In 2016, hydrogen sulfide $\left(\mathrm{H}_{2} \mathrm{~S}\right)$ emissions were found during the maintenance of a hydraulic system at the Blue River Dam, Oregon. Hydrogen sulfide is potentially toxic and explosive, therefore, determining the cause of this gas is needed. Three possibilities were considered most likely - the thermal transformation of Zinc Dialkyl Dithiophosphate (ZDDP), a sulfur containing additive to the hydraulic oil, abiotic hydrolysis reaction of the ZDDP, or the microbial mediated reduction of sulfur. This project, conducted by the U.S. Army Engineer Research and Development Center (ERDC) and supported the Portland District (NWP), contains studies that explore sulfide in the hydraulic oil and associated water. The ERDC also explored for evidence of sulfur reduction by microbial activity. The goal was to narrow down the possible causes of this sulfide gas, particularly exploring the hypothesis that the sulfide generation was due to microbial activity.

\subsection{Sulfur forms}

\subsubsection{Elemental sulfur}

Sulfur can exist in several forms. Elemental sulfur refers to it in its purist state. Elemental sulfur is typically a yellowish powdery solid and has a charge of zero (o). However, it typically is reactive and forms oxidative and reduced states.

\subsubsection{Sulfate}

Sulfate is the oxidized state of sulfur. Its typical form is $\mathrm{SO}_{4}{ }^{2-}$, and its charge is +6 . Sulfur dioxide is another oxidized form of sulfur with a charge of +4 , but it is not common in aqueous systems. Sulfate is usually non-problematic, although it can be associated with sulfuric acid (see section 1.2.4).

\subsubsection{Sulfide}

Sulfide is the reduced form of sulfur. It is commonly found dissolved in water as hydrosulfide ion (HS-) and has a charge of -2. Sulfide is also the 
form found in the toxic gas hydrogen sulfide $\left(\mathrm{H}_{2} \mathrm{~S}\right)$. Sulfide gas is highly offensive smelling at low concentrations. Sulfide gas has a characteristic "rotten egg odor" at airborne concentrations of 0.02 part per million based on volume (gas concentration) (ppmv) (Nicholson and O’Brien 2001). Sulfide gas actually becomes odorless at higher concentrations because it paralyzes the olfactory system. However, as concentrations increase, hydrogen sulfide becomes increasingly toxic and potentially explosive. Table 1 summarizes $\mathrm{H}_{2} \mathrm{~S}$ toxicity.

Table 1. Hydrogen Sulfide toxicity and explosive characteristics (sources: Nicholson and O'Brien 2001; NIOSH 2005).

\begin{tabular}{|c|c|}
\hline Elfactory Detection (rotten egg odor) & Concentration/Temperature \\
\hline $\begin{array}{c}\text { Recommend Exposure Limit (REL) - A level recommended by the } \\
\text { National Institute of Occupational Safety and Health (NIOSH) for } \\
\text { adoption by the Occupational Safety and Health Administration } \\
\text { (OSHA) as a new permissible exposure limit (PEL) level }\end{array}$ & 10 ppmv (10 minutes) \\
\hline $\begin{array}{c}\text { Permissible Exposure Limit (PEL) - An enforceable exposure limit } \\
\text { established by OSHA. Time Weighted Average based on an 8- } \\
\text { hour work period. }\end{array}$ & 20 ppmv, 50 ppmv 10-minute peak \\
\hline $\begin{array}{c}\text { Immediately Dangerous to Life and Health (IDLH) - A NIOSH } \\
\text { defined concentration where life and health is immediately } \\
\text { endangered if exposed. }\end{array}$ & 100 ppmv \\
\hline Lethal Concentration 50 (LC50) (rat, 1-hour) & 713 ppmv \\
\hline Lower and Upper Explosive Limits (LEL-UEL) & 4.3 to $46 \%$ \\
\hline $\begin{array}{c}\text { Flashpoint (FP) - the lowest temperature the chemical can form } \\
\text { an ignitable mixture in air. }\end{array}$ & $-82.4{ }^{\circ} \mathrm{C} /-116.3^{\circ} \mathrm{F}$ \\
\hline $\begin{array}{c}\text { Auto-ignition Temperature - The lowest point a chemical will } \\
\text { ignite in a normal atmosphere without an ignition source. }\end{array}$ & $232^{\circ} \mathrm{C} / 450{ }^{\circ} \mathrm{F}$ \\
\hline
\end{tabular}

Hydrogen sulfide is heavier than air with a vapor density of 1.36 grams per liter $(\mathrm{g} / \mathrm{L})$. This means that the gas will commonly concentrate in low lying areas and depressions making ventilation of the gas challenging in some instances.

\subsubsection{Sulfide/sulfate cycling}

When sulfur forms are subjected to cyclic reductive and oxidative reactions, the results are usually detrimental. Reductive reactions form sulfides, that then form sulfide gas $\left(\mathrm{H}_{2} \mathrm{~S}\right)$, (described in section 1.2.3). This gas is toxic and explosive.

When hydrogen sulfide becomes exposed to oxygen, it can react to form sulfate. In water, this reaction forms sulfuric acid (Equation 1) 


$$
\mathrm{H}_{2} \mathrm{~S}+2 \mathrm{O}_{2}=\mathrm{SO}_{4}{ }^{2-}+2 \mathrm{H}^{+}
$$

These acids can irritate breathing tissues and the eyes. In addition, acid forming reactions can cause corrosion problems. If the sulfate is reduced again, issues with hydrogen sulfide can again arise.

\subsubsection{Organic sulfur}

Sulfur can also be incorporated into organic compounds referred to as organic sulfur. Total sulfur refers to all forms of sulfur in a given aqueous system, this includes organic and inorganic forms:

Total Sulfur $=$ Elemental Sulfur + Sulfate + Sulfide + Organic Sulfur

To account for differences in molecular masses, molar concentrations can be used. However, molar values are often not very intuitive. An alternative is to convert concentrations to $\mathrm{mg} / \mathrm{L}$ or $\mathrm{mg} / \mathrm{kg}$ as sulfer (S), as shown in Equation 2

$$
X m g / L \text { as } S=Y m g / L x\left(M W_{\text {Sulfur }} / M W\right)
$$

Where $X$ is the concentration as $\mathrm{S}, Y$ is the concentration of the actual molecule of interest, $\mathrm{MW}_{\text {sulfur }}$ is the molecular weight of sulfur $(32 \mathrm{~g} / \mathrm{mol})$ and the molecular weight (MW) of the actual compound ( $96 \mathrm{~g} / \mathrm{mol}$ for sulfate and $33 \mathrm{~g} / \mathrm{mol}$ for sulfide).

\subsection{Dams studied in this project}

This project studied samples from three dams in Oregon: Blue River, Hill Creek, and Cougar. Blue River Dam, was the site of the sulfide release event. Samples from Hill Creek Dam and Cougar Dam, two other dams with similar hydraulic systems were also taken and tested. All of these dams are in relatively close proximity to each other and are part of the Willamette Valley Project, a flood control project consisting of 13 smaller dams (Figure 1) that are operated by the United States Army Corps of Engineers (USACE) Portland District (NWP). 
Figure 1. The Willamette Valley Project with locations of dams and facilities. Dams in this study are circled in bright red. (base map from USACE,

http://www.nwp.usace.army.mil/Locations/Willamette-Valley/).

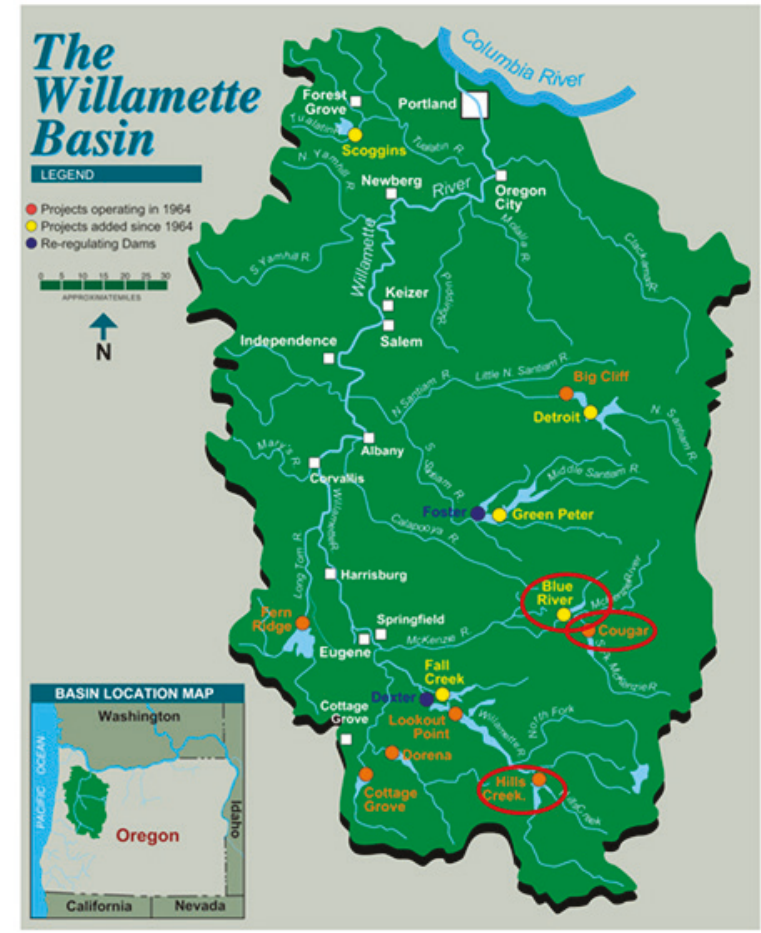

\subsubsection{Blue River Dam}

The Blue River Dam is a flood control dam built in 1968 and operated by the USACE (Figure 2). The Blue River Dam forms a six mile long impoundment on the Blue River and is located in west central Oregon.

Figure 2. Blue River Dam, Oregon.

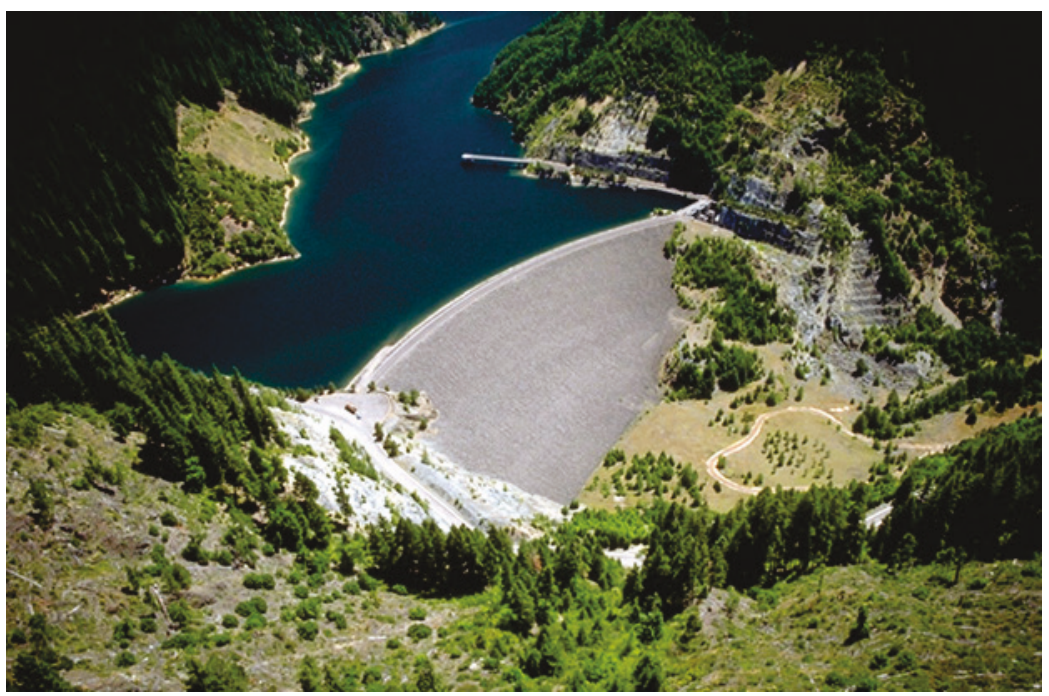




\subsubsection{Cougar Dam}

Cougar Dam, built in 1963, is located on the South Fork of the McKenzie River and forms the Cougar Reservoir. It is primarily a flood control facility, but it does have hydropower production. Cougar Dam has a similar hydraulic system to Blue River Dam, and it uses the same hydraulic oil (Chevron Rando ${ }^{\circledR}$ HD, see section 1.9.3).

\subsubsection{Hills Creek Dam}

Hills Creek Dam was constructed in 1961 and is primarily a flood control and water storage facility, although it does have hydropower generation. Hills Creek has a similar, but older hydraulic system. Because the dam is older, it uses a different hydraulic oil (Chevron Hydraulic Oil AW) than the Blue River and Cougar Dams. The Chevron Hydraulic Oil AW does not contain the ZDDP additive (see section 1.9.4).

\subsection{Intake tower}

Intake towers are vertical structures in reservoirs that routinely convey water as part of the reservoirs operation. For many reservoirs, intake towers provide water for hydroelectric turbines or for water treatment for potable uses. In the case of the Blue River Dam, the intake tower is used to regulate routine releases as part of its mission for flood risk management, recreation, irrigation, and maintenance water quality in the Willamette Valley. Figure 3 is a schematic of Blue River Dam's intake tower. The purpose of the intake tower hydraulic system is to control valves that regulate water levels in the dam. 
Figure 3. Schematic of the intake tower (adapted from Crocker 2016).

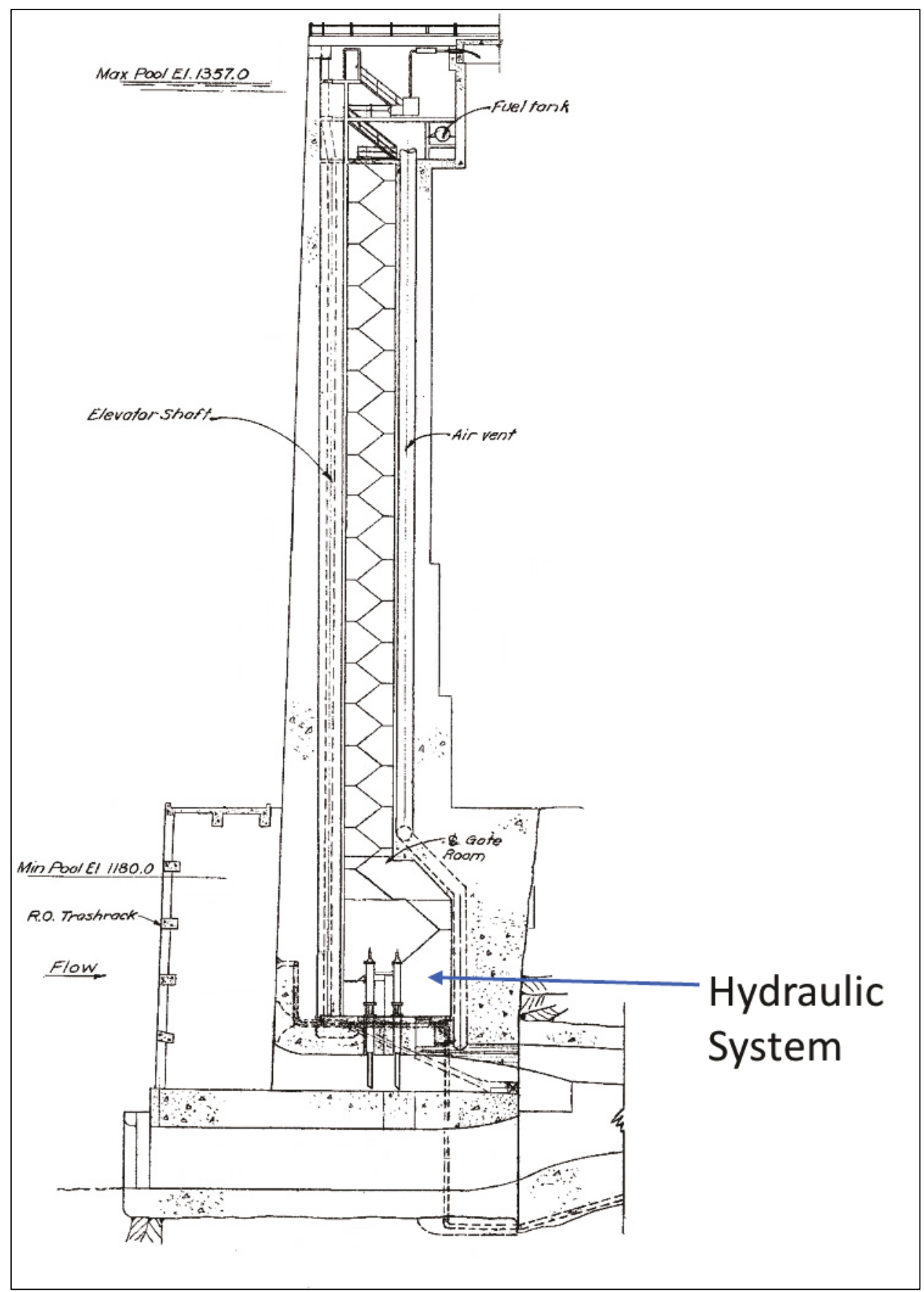

\subsection{Hydraulic system}

Figure 4 is a schematic of the hydraulic system showing service gates, control unit, sump, and filters. Figure 5 includes schematics of the control unit. Figure 6 shows the control unit with key sample locations including the tank heater. The tank heater is a Chromalox brand electric immersion heater (2kW, $15 \mathrm{~W} / \mathrm{in}^{2}$, set to $\left.80{ }^{\circ} \mathrm{F}\right)$, model number ARMTO-2020 E1T1. 
The tank heater maintains the hydraulic oil at an ideal temperature so that it is at the correct operating viscosity at all times (reducing system pressures and stresses) as well as maintaining a temperature to prevent condensation inside the Hydraulic Power Unit (HPU) reservoir (preventing water intrusion). Temperature gauges record the oil temperature in the sump to insure it does not get too hot (Figure 7). In addition, the hydraulic system has a filtration system to keep the oil free of particulates (Figure 8). Locations of these Figures can be related to the sample locations discussed in the Materials and Methods Section. The system can adjust to changes of pressure using breathers. Reservoir size is 225 gallons, 36 in. $\mathrm{W} \times 72$ in. $\mathrm{L} \mathrm{x}$ $23.5 \mathrm{in.} \mathrm{H}$; the typical volume is $150-200$ gallons. The breathers are a desiccant style breather (Hydac Brand with Beta $3=200$ ).

Figure 4. Schematic of the Blue River Dam regulating outlet hydraulic system.

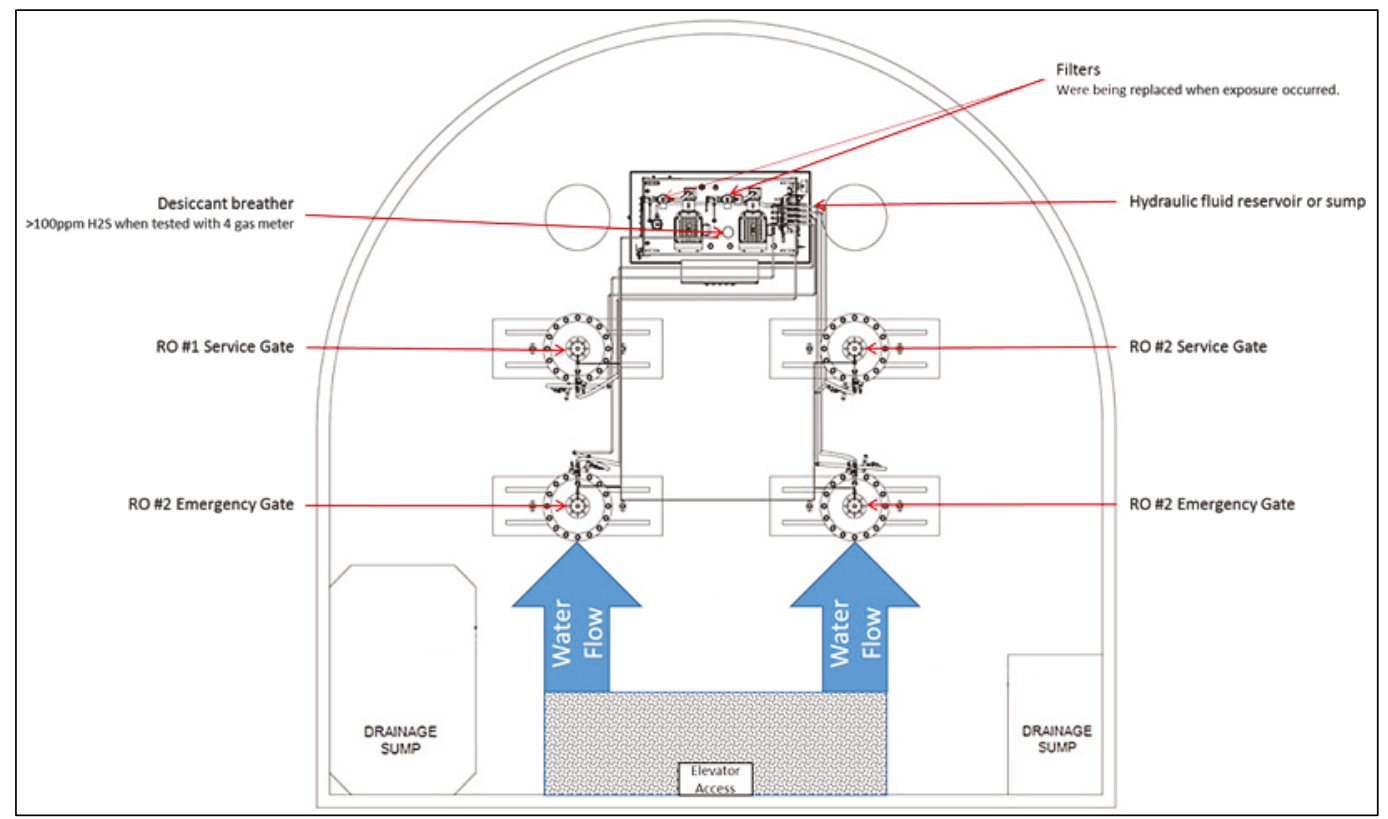


Figure 5. Schematic of the Blue River Dam hydraulic system.

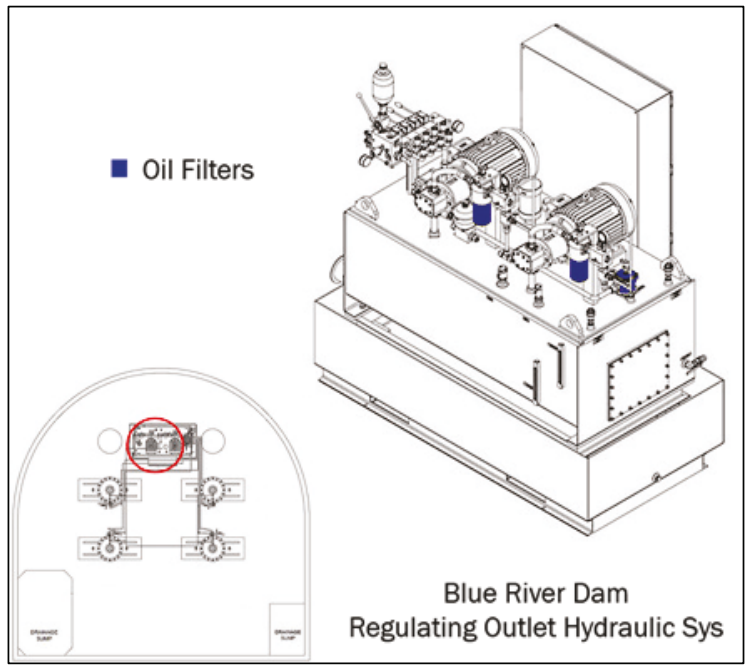

Figure 6. Labelled photograph of the hydraulic fluid system showing key sampling locations.

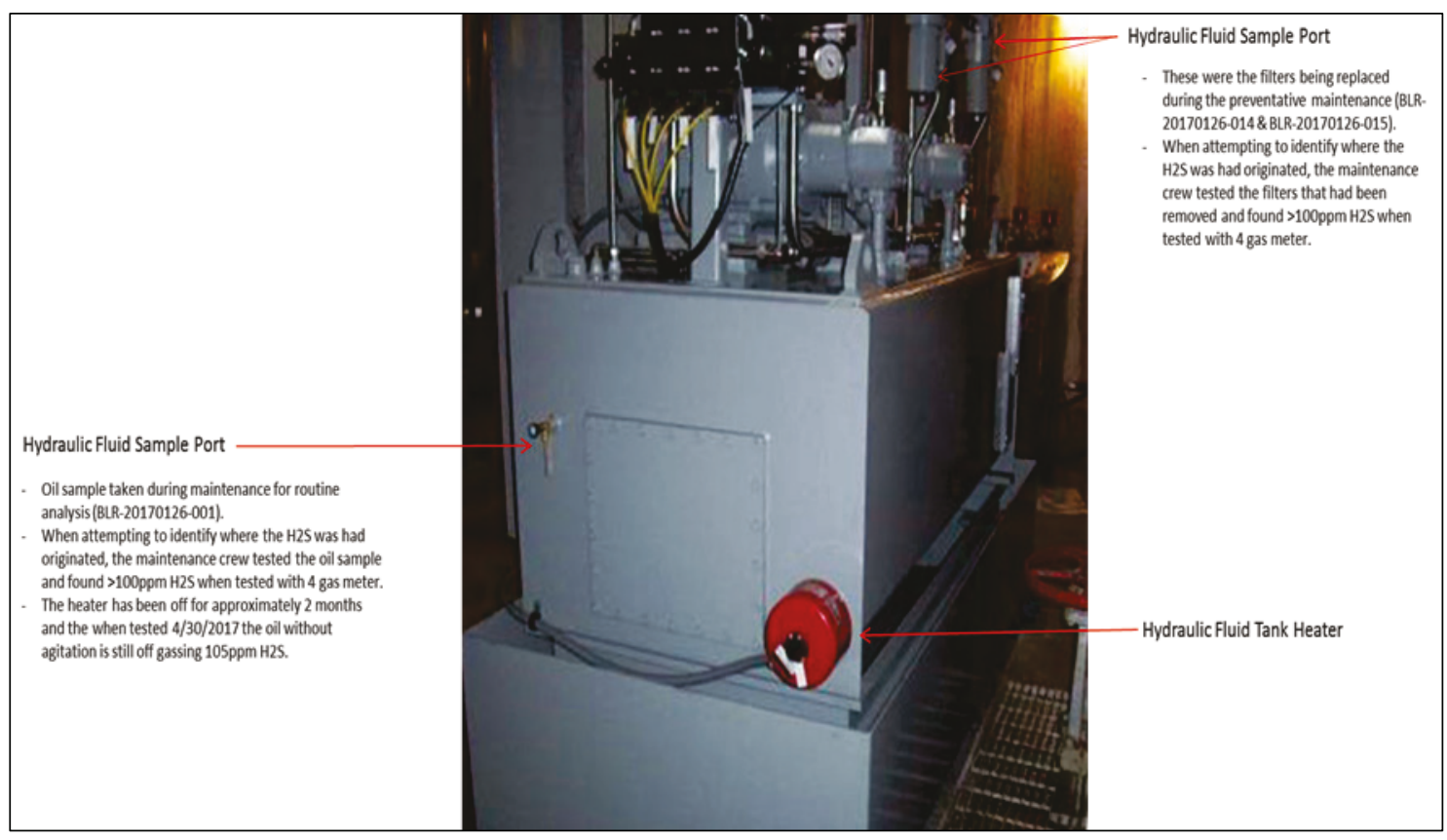


Figure 7. Blue River hydraulic system oil sump temperature gauge.

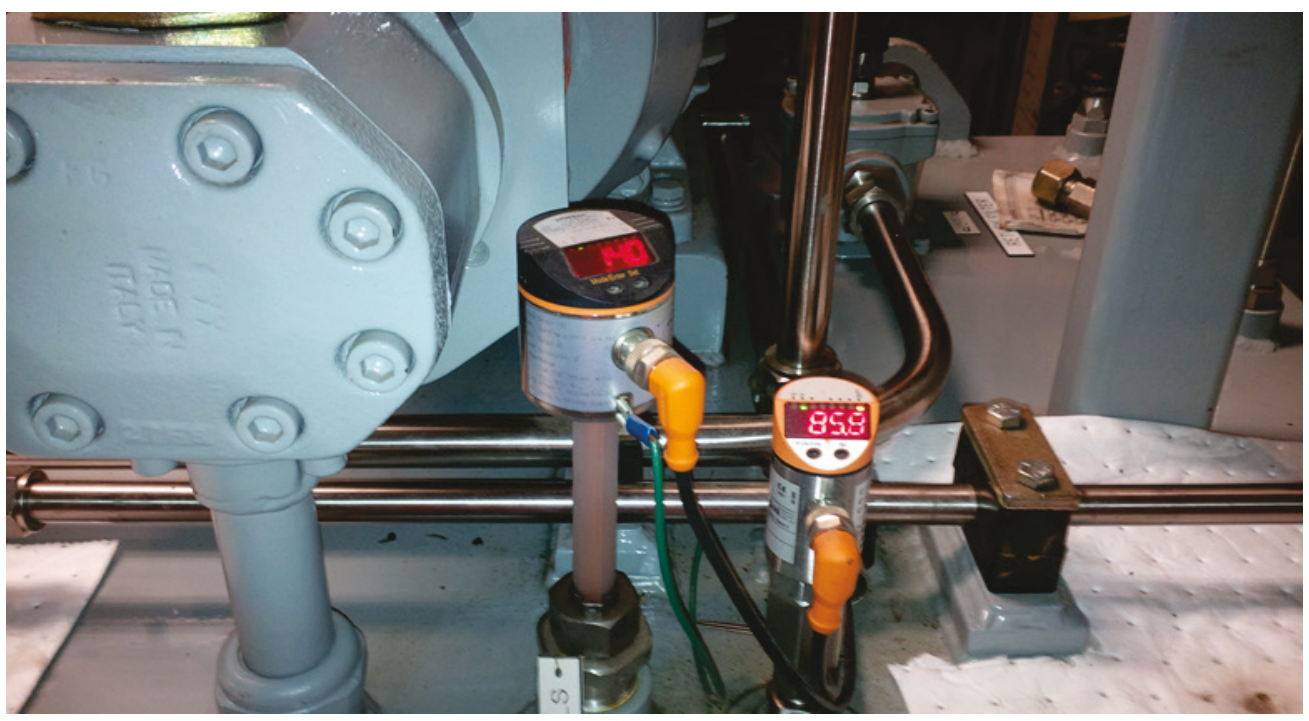

Figure 8. Blue River hydraulic oil system return filter housing.

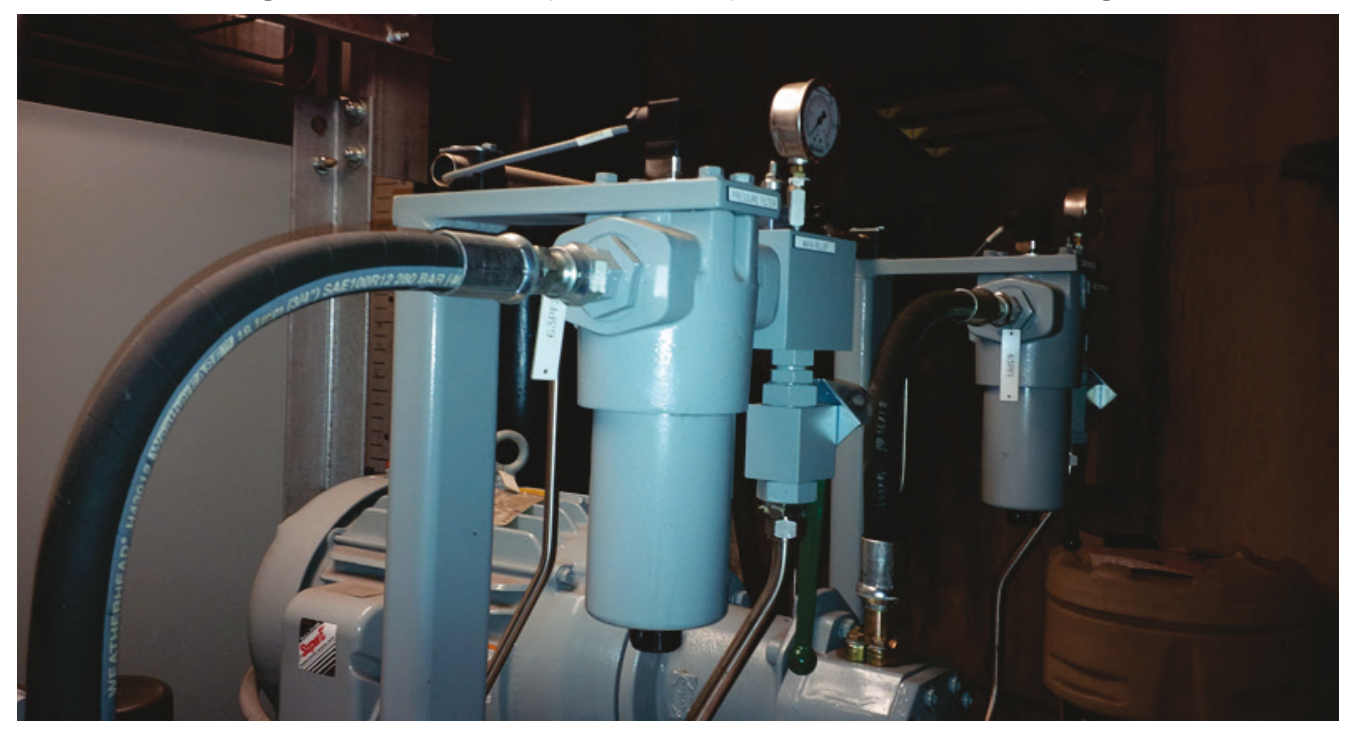

\subsection{Description of the event}

Information on the sulfide release event that occurred in October 2016, was obtained through a review of two sources; the summary document (prepared by Catherine Campbell), USACE NWP (Appendix 1), and from a presentation (Crocker 2016). During maintenance in the room containing the hydraulic system, four workers (of a team of five) were affected by hydrogen sulfide gas. A brief rotten egg odor was reported. Interviews conducted by the Board of Inquiry (BOI) indicated that the Project personnel were most strongly affected by the $\mathrm{H}_{2} \mathrm{~S}$ when the pump motor blowers were blowing air from the sump breather into their faces. Reported symptoms were correlated with distance from the sump tank (Table 2). 
Table 2. Distance from hydraulic oil sump tank vs. symptoms (adapted from Crocker 2016).

\begin{tabular}{|c|c|c|c|c|c|}
\hline \multirow{2}{*}{ Symptom } & \multicolumn{5}{|c|}{ Distance from Hydraulic Oil Sump Tank } \\
\hline & $<1 \mathrm{ft}$ & $\mathbf{2} \mathrm{ft}$ & $\mathbf{3 f t}$ & $10 \mathrm{ft}$ & $<10 \mathrm{ft}$ \\
\hline Nose irritation & $\mathrm{X}$ & $\mathrm{X}$ & $\mathrm{X}$ & & \\
\hline Eye irritation & $\mathrm{X}$ & $\mathrm{X}$ & $\mathrm{X}$ & & \\
\hline Throat irritation & $\mathrm{X}$ & & $\mathrm{X}$ & & \\
\hline Headache & $\mathrm{X}$ & $\mathrm{X}$ & $\mathrm{X}$ & $\mathrm{X}$ & \\
\hline Fatigue & $\mathrm{X}$ & $\mathrm{X}$ & & & \\
\hline Disorientation & $\mathrm{X}$ & & & & \\
\hline Memory loss & $\mathrm{X}$ & & & & \\
\hline Tightening in chest & $\mathrm{X}$ & $\mathrm{X}$ & $\mathrm{X}$ & & \\
\hline Coughing & $\mathrm{X}$ & & $\mathrm{X}$ & & \\
\hline Difficulty breathing & $\mathrm{X}$ & & & & \\
\hline
\end{tabular}

An $\mathrm{H}_{2} \mathrm{~S}$ meter was used to assess the sulfide gas in the hydraulic room. The oil sample and the breather on the sump tank caused the $\mathrm{H}_{2} \mathrm{~S}$ meter to deflect to its maximum of 100 ppmv (15 ppmv is the Short Term Exposure Limit [STEL] for $\mathrm{H}_{2} \mathrm{~S}$ ). However, $\mathrm{H}_{2} \mathrm{~S}$ did not register on the meter anywhere else in the tower. All of these observations suggest that the hydraulic oil was the primary source of the $\mathrm{H}_{2} \mathrm{~S}$ gas.

\subsection{Sulfide in oil}

Sulfur is commonly found in petroleum, usually organic in form, as impurities to various hydrocarbon compounds that make up the oil. Different crude oil sources have different amounts of sulfur in their composition. Those with total sulfur concentrations of $0.5 \%(5000 \mathrm{mg} / \mathrm{kg})$ are considered to have high sulfur concentrations and are referred to as sour. Crude oil with sulfur concentrations $<0.42 \%$ are considered low in sulfur and are referred to as sweet. In crude oil reservoirs, conversion of elemental and organic sulfur to sulfate, then sulfide, is common. The high organic environment creates an ideal environment for reductive microbial reactions and abiotic thermochemical reductive reactions that result in the formation of hydrogen sulfide (Marriott et al. 2015). Modern production methods, including steam assisted gravity drainage and hydraulic fracturing, can actually stimulate sulfide transformation in the production process. Additional chemical additives used in production can add sulfur to the system (Lipus et al. 2017).

However, refined products have sulfur concentrations that are much lower. First, there are many crude sources that have low sulfur content 
(referred to as sweet). Second, refining processes allow for sulfur removal from sour sources. That said, even after refining, it is common for oils to have sulfur concentrations containing $10 \mathrm{~s}$ of $\mathrm{mg} / \mathrm{kg}$. Additives, however, (such as ZDDP, section 1.9.4) can increase the sulfur content.

As long as this sulfur remains in an elemental or organic form, it does not represent a hazard. However, if it is converted to sulfide, then the oil becomes a source of hydrogen sulfide gas. According to Nicholson and O'Brien (2001), $1 \mathrm{mg} / \mathrm{kg}$ of $\mathrm{H}_{2} \mathrm{~S}$ in oil can result in a vapor concentration of 50 ppmv, this is above the PEL and equivalent to the 10-minute exposure peak (Table 1).

\subsection{Hydraulic systems}

Many locks and dams are now using hydraulic power systems to operate gates and valves, essentially replacing mechanical drive systems. These systems offer major advantages over mechanical devises like pulleys, levers and gears such as the following:

1. High power to size ratio,

2. Forces can be transmitted over a great distance,

3. Allows large loads to be moved by small forces,

4. Almost infinite speed and forces, speed can be adjusted to meet varying requirements,

5. Can serve many actuators/applications at one time, and

6. Fluid does not break, however, it can become contaminated. Keeping hydraulic fluid clean and dry is critical for proper operation of hydraulic power systems.

\subsection{Hydraulic oil}

Hydraulic systems rely on fluid or oil pressure to operate. In order to maintain operating pressure, hydraulic oil should be "stiff," (have a high bulk modulus for position stability), should be free of air and water to the best extent possible, and have the ability to transfer heat. Hydraulic oil (when conditioned) flow can carry "cool oil" to cool a heat sensitive component, or, "carry-off heat" away from a component that's oil is exposed to a high temperature.

One of the most important elements of any hydraulic system is the type and quality of the oil. Frequent maintenance of the oil is essential for 
maintaining high performance operation, equipment reliability, and component life. Hydraulic Oil is assigned International Organization for Standardization (ISO) viscosity grades (VG) ranging from 32 to 68.

An appropriate hydraulic oil should protect against wear of the hydraulic system components. This may involve the use of additive packages to enhance this property. Systems in dams and locks frequently have long pipe runs that can have high variation in temperature. An oil should have proper viscosity to maintain sealing and lubrication in such a setting. Corrosion protection is important, and additives are frequently used to enhance this property. The oil must also be compatible with seals and hoses in the system.

There are three-categories of oil commonly used: 1) petroleum based fluids, 2) biodegradable (or environmentally acceptable), and 3) fire resistant fluids. The three dams in this study all use petroleum based hydraulic oils.

\subsubsection{Additives}

Hydraulic oils frequently contain additives that serve the following three purposes:

- Modify the properties of the base fluid - improve viscosity index (VI), lower pour point, and reduce foaming,

- Protect the lubricant- slow down oxidation, and

- Protect the equipment - reduce corrosion and protect against wear.

Temperature can affect hydraulic oil performance. If the oil is too cold, any moisture in the oil can precipitate, hydrolyzing the oil. However, if oil is too hot, seals can become damaged, acids can form in the oil, and sludge and varnish can form, all of these can damage the performance of the oil.

\subsubsection{Water in hydraulic oil}

Water is common in hydraulic oil systems in dams, particularly those that control submerged valves and gates. The systems are under high pressure and it is difficult to insure that seals and pipe joints are completely water tight. Water can seep into the system in this manner. Water can also enter the reservoir through breathers. As outside air is heated up during the day and cooled at night, water can condense out. 
Water can exist as free water (a separate phase), dissolved (small quantities [up to 200 to $300 \mathrm{mg} / \mathrm{kg}$ ] dissolved in the oil), or emulsified (a pseudo-stable oil/water mixture creating a milky mixture, water composing up to $1 \%)$. The saturation point is the highest level water can dissolve into a given oil. If the saturation point is exceeded, water will form a free phase.

However, water in the system is not desirable (Kopecky 2004). Water can lead to oil degradation, corrosion, wear, and poor lubrication. Water can also stimulate microbial activity. Microorganisms can degrade the oil, causing biofilms that result in fouling. Water can also react with additives in the fluid. Of particular concern is reaction with ZDDP (Kopecky 2004), this is discussed in section 1.9.4. Although it is ideal that water content be completely eliminated, this is not always practical. However, $200 \mathrm{mg} / \mathrm{kg}$ is considered the threshold where the negative effects of water are minimized (Kopecky 2004).

\subsubsection{Rando $^{\circledR}$ oil}

Both Blue River Dam and Cougar Dam use Chevron Rando ${ }^{\circledR}$ HD hydraulic oil in their systems. This is a premium, petroleum based hydraulic oil designed to work in challenging environments. The oil contains anti-wear additives to minimize wear, contains rust inhibition packages, and is designed to be easily filtered in the presence of water. It resists foaming and has good gas release properties. Appendix 2 contains a product description sheet and a material safety data sheet (MSDS) for Chevron Rando ${ }^{\circledR}$ HD.

\subsubsection{ZDDP additive}

ZDDP is a common additive to lubrication and hydraulic oils. The purpose of this additive is to reduce wear when it is blended with oil products in concentrations of up to 30\% ([American Chemistry Council] ACC 2015). Figure 9 shows a generalized chemical structure for ZDDP. The form in the Chevron Rando Oil ${ }^{\circledR}$ is identified by Chemical Abstract Services (CAS) 68649-42-3, this has a chemical formula of $\mathrm{C}_{28} \mathrm{H}_{60} \mathrm{O}_{4} \mathrm{P}_{2} \mathrm{~S}_{4} \mathrm{Zn}$. 
Figure 9. Chemical structure of ZDDP.

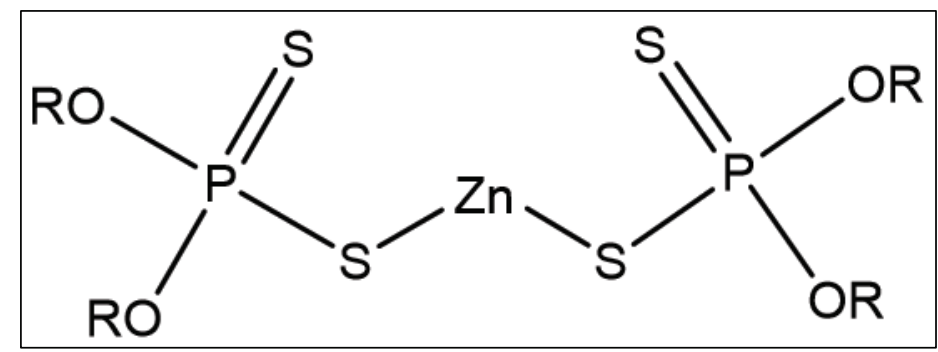

ZDDP can thermally decompose and form $\mathrm{H}_{2} \mathrm{~S}$ (ACC 2015). Other gases can also be formed included mercaptans and olefins. ZDDP can also hydrolyze with water to release hydrogen sulfide and sulfuric acid (Kopecky 2004; ACC 2015). A proposed balanced equation for this reaction is

$\mathrm{C}_{28} \mathrm{H}_{60} \mathrm{O}_{4} \mathrm{P}_{2} \mathrm{~S}_{4} \mathrm{Zn}+60 \mathrm{H}_{2} \mathrm{O}=8 \mathrm{Zn}+27 \mathrm{H}_{2} \mathrm{~S}+5 \mathrm{H}_{2} \mathrm{SO}_{4}+16 \mathrm{H}_{3} \mathrm{PO}_{4}+8$ $\mathrm{C}_{28} \mathrm{H}_{60} \mathrm{OH}$ (Equation balanced by Mr. Justin La)

The reaction is catalyzed by higher temperatures. 


\section{Materials and Methods}

\subsection{Quality assurance plan (QAP)}

ERDC prepared a quality assurance plan (QAP) for the study, this is provided in Appendix 3.

\subsection{Samples}

Samples from three dams (Blue River Dam, Cougar Dam, and Hills Creek Dam) were collected by NWP (Figure 10). The total number of samples were seventeen hydraulic oil samples (Table 3) and four water samples (two from Blue River Dam, and one each from Cougar Dam and Hills Creek Dam). Two of the samples were "new" oil, meaning that they were unused Chevron Rando oil. The ERDC also received two filter samples from the Blue River Dam.

Figure 10. Samples collected for the study.

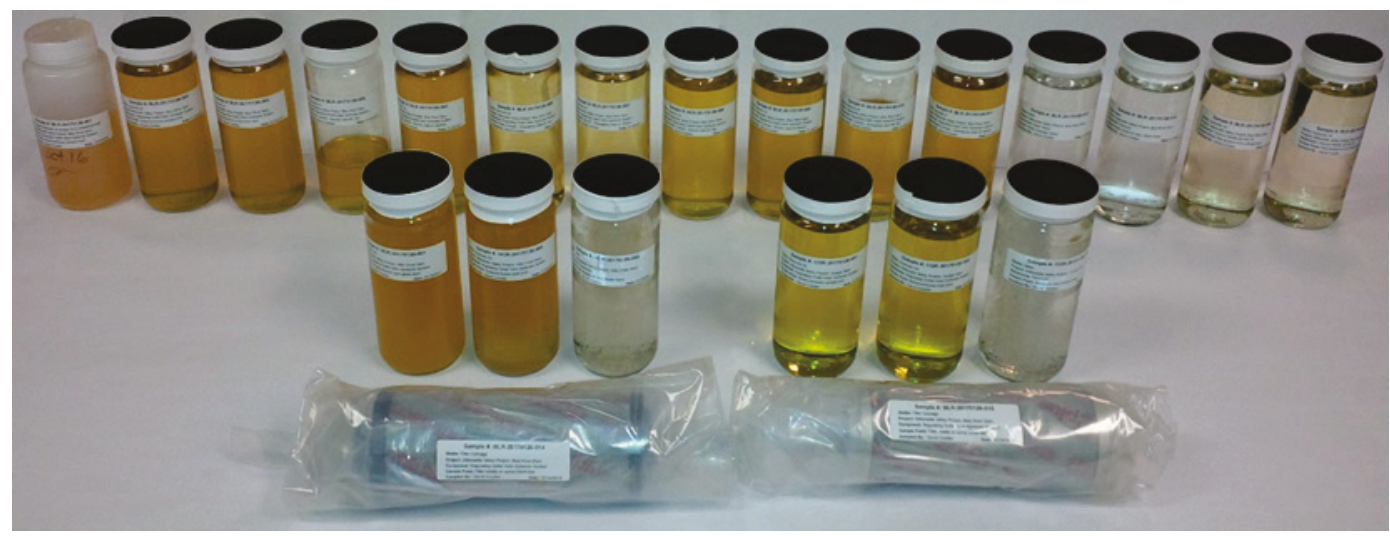


Table 3. Hydraulic oil samples collected for this study.

\begin{tabular}{|c|c|c|}
\hline \begin{tabular}{|l} 
Sample \\
Number
\end{tabular} & Date & Sample Location \\
\hline \multicolumn{3}{|l|}{ Blue River } \\
\hline 1 & $10 / 18 / 2016$ & Original Oil \\
\hline 2 & $1 / 28 / 2017$ & HPU oil sump tank sample port \\
\hline 3 & $1 / 28 / 2017$ & HPU oil sump tank drain port \\
\hline 4 & $1 / 28 / 2017$ & RO \# 1 Service Port \\
\hline 5 & $1 / 28 / 2017$ & RO \# 1 Service Bottom \\
\hline 6 & $1 / 28 / 2017$ & RO \#1 Emergency Top \\
\hline 7 & $1 / 28 / 2017$ & RO \# 1 Emergency Bottom \\
\hline 8 & $1 / 28 / 2017$ & RO \#2 Service Top \\
\hline 9 & $1 / 28 / 2017$ & RO \# 2 Service Bottom \\
\hline 10 & $1 / 28 / 2017$ & RO \#2 Emergency Top \\
\hline 11 & $1 / 28 / 2017$ & RO \#2 Emergency Bottom \\
\hline 16 & $1 / 28 / 2017$ & Chevron Rando HD-ISO-32 NEW Oil \\
\hline 17 & $1 / 28 / 2017$ & Chevron Rando HD-ISO-32 NEW Oil \\
\hline \multicolumn{3}{|l|}{ Cougar Dam } \\
\hline 1 & $1 / 28 / 2017$ & HPU oil sump tank sample port \\
\hline 2 & $1 / 28 / 2017$ & HPU oil sump tank drain port \\
\hline \multicolumn{3}{|c|}{ Hills Creek Dam } \\
\hline 1 & $1 / 28 / 2017$ & HPU oil sump tank sample port \\
\hline 2 & $1 / 28 / 2017$ & HPU oil sump tank drain port \\
\hline
\end{tabular}

The following water samples were collected:

- Blue River Dam (BLR)-12 - drainage sump. 01/28/2017.

- BLR-13 - reservoir near intake tower. 01/28/2017.

- Cougar Dam (CGR)-3 - reservoir near intake tower. 01/28/2017.

- Hills Creek Dam (HCR)-3 - reservoir near intake tower. 01/28/2017.

\subsubsection{Oil sample studies}

Oil samples were studied for the analytes specified in Table 4. Contract laboratories were used for these analyses as indicated. These analyses were conducted by Air, Water \& Soil Laboratories, Inc. (Richmond, VA). 
Table 4. Analytes for hydraulic oil samples collected for sulfide study.

\begin{tabular}{|c|c|c|}
\hline Analyte & Method & Detection Limit \\
\hline Water Content & $\begin{array}{c}\text { American Society for Testing } \\
\text { and Materials (ASTM) D95 }\end{array}$ & $10 \mathrm{mg} / \mathrm{kg}$ (estimated) \\
\hline Acid Neutralization Number & ASTM D664 & Up to $0.01 \mathrm{mg} / \mathrm{kg}$ \\
\hline Zinc & $\begin{array}{c}\text { USEPA Method } 6010 \mathrm{C}(\mathrm{SW}- \\
846)\end{array}$ & $0.5 \mathrm{mg} / \mathrm{kg}$ \\
\hline Sulfur & $\begin{array}{c}\text { USEPA Method } 6010 \mathrm{~B}(\mathrm{SW}- \\
846)\end{array}$ & $8.33 \mathrm{mg} / \mathrm{kg}$ \\
\hline
\end{tabular}

Water content, zinc, sulfur, and acid numbers were analyzed by a contract laboratory. Sulfur reducing microorganisms were analyzed at ERDC.

\subsubsection{Water samples}

Water samples were measured for the analytes specified in Table 5. The analyses were conducted by the Environmental Chemistry Branch (EPC) of ERDC (Vicksburg, MS) using the United States Environmental Protection Agency (USEPA) method listed.

Table 5. Analytes for water samples collected for sulfide study.

\begin{tabular}{|c|c|c|}
\hline Analyte & Method & Detection Limit \\
\hline $\mathrm{pH}$ & USEPA Method 150.1 & $0.01 \mathrm{units}$ \\
\hline Specific conductance & USEPA Method 120.1 & $1 \mathrm{uS} / \mathrm{cm}$ \\
\hline Sulfate & USEPA Method $9035(\mathrm{SW}-846)$ & $0.004 \mathrm{mg} / \mathrm{L}$ \\
\hline Sulfide & USEPA Method 376.2 & $0.01 \mathrm{mg} / \mathrm{L}$ \\
\hline Zinc & USEPA Method $6020(\mathrm{SW}-846)$ & $0.002 \mathrm{mg} / \mathrm{L}$ \\
\hline Sulfur & USEPA Method $6010(\mathrm{SW}-846)$ & $\mathrm{mg} / \mathrm{L}$ \\
\hline
\end{tabular}

\subsubsection{Hydraulic filters}

The ERDC received two hydraulic oil filter samples from Blue River Dam. The oil filters were Hydac brand filters, model 0240Doo5BN4HC (5 micron, Beta $5=1000$ ). These filters were taken apart and separated into different components that were then studied at 8-100X magnification using a Leica MX12.5 Stereo microscope (https://www.meyerinst.com/htm//leica/mz125/ mz125.htm). Pictures were taken to document the results.

\subsubsection{Sulfur reducing microorganisms}

The study included seventeen hydraulic oil and water samples from the three dams. Appendix 4 contains the report on this portion of the study, 
and it discusses the methods in detail. In summary, genetic probes were used to search for microbial activity and sulfur reducing microorganisms in both oil and water samples. Samples were explored using the two following primers:

- The first searched for bacterial DNA (deoxyribonucleic acid),

- If the first was positive, then the second searched for genetic material associated with sulfate reducing bacteria. 


\section{Results}

\subsection{Chemical analyses}

\subsubsection{Hydraulic oil}

Table 6 summarizes the analytical data for the hydraulic oil samples. Subsequent sections will refer back to these results.

Table 6. Summary of results of hydraulic oil analyses.

\begin{tabular}{|c|c|c|c|c|}
\hline Sample ID & $\begin{array}{c}\text { Acid Neutralization } \\
(\mathrm{mgKOH} / \mathrm{g})\end{array}$ & $\begin{array}{c}\text { Water, \% } \\
\text { (wt\%) }\end{array}$ & $\begin{array}{c}\text { Zinc } \\
(\mathrm{mg} / \mathrm{kg})\end{array}$ & $\begin{array}{l}\text { Sulfur } \\
(\mathrm{mg} / \mathrm{kg})\end{array}$ \\
\hline Method & ASTM D664 & ASTM D6304 & EPA $6000 / 7000$ & $\begin{array}{l}\text { Digestion: SW-846 } \\
\text { 3050B. Analysis by } \\
\text { ICPMS SW-846 6010B }\end{array}$ \\
\hline \multicolumn{5}{|l|}{ Blue River Dam } \\
\hline BLR-20170126-001 & 0.14 & 0.051 & 180 & 126 \\
\hline BLR-20170126-002 & 0.25 & 0.028 & 162 & 94.7 \\
\hline BLR-20170126-003 & 0.23 & 0.015 & 166 & 139 \\
\hline BLR-20170126-004 & 0.23 & 0.017 & 157 & 148 \\
\hline BLR-20170126-005 & 0.14 & 0.012 & 161 & 152 \\
\hline BLR-20170126-006 & 0.29 & 0.016 & 232 & 147 \\
\hline BLR-20170126-007 & 0.29 & 0.015 & 270 & 145 \\
\hline BLR-20170126-008 & 0.28 & 0.092 & 224 & 170 \\
\hline BLR-20170126-009 & 0.48 & 0.077 & 197 & 176 \\
\hline BLR-20170126-010 & 0.27 & 0.024 & 206 & 124 \\
\hline BLR-20170126-011 & 0.24 & 0.029 & 209 & 118 \\
\hline BLR-20170126-016 & 0.25 & 0.021 & 420 & 150 \\
\hline BLR-20170126-017 & 0.32 & 0.013 & 401 & 147 \\
\hline \multicolumn{5}{|l|}{ Cougar Dam } \\
\hline CGR-20170126-001 & 0.21 & 0.169 & 380 & 90.8 \\
\hline CGR-20170126-002 & 0.27 & 0.056 & 392 & 407 \\
\hline \multicolumn{5}{|l|}{ Hills Creek Dam } \\
\hline HCR-20170126-001 & 0.03 & 3.35 & & 476 \\
\hline HCR-20170126-002 & 0.11 & 44.8 & BLD & 384 \\
\hline
\end{tabular}

\subsubsection{Total sulfur in hydraulic oil}

Figure 11 summarizes the total sulfur in the hydraulic oil samples. All of the oil samples had sulfur contents of at least $90.8 \mathrm{mg} / \mathrm{kg}$. This indicates that there is sufficient sulfur in the oil samples to serve as a source of hydrogen sulfide. Blue River Dam samples sulfur content ranged from 94.7 to $170 \mathrm{mg} / \mathrm{kg}$. Fresh oil samples (Blue River Dam 16 and 17) had sulfur levels of approximately $150 \mathrm{mg} / \mathrm{kg}$ ( 147 and 150 respectively). Samples 4, 5, 6, and 7 had levels ranging from 145 to $152 \mathrm{mg} / \mathrm{kg}$, or approximately the same as that of the base oil. Samples 8 and 9 (RO\#2 Top and Bottom respectively) had sulfur concentrations of 170 to 176 , or slightly enhanced sulfur content. Conversely, samples 1, 2, 3, 10 and 11 had sulfur levels lower than that of the base oil ( 94.7 to $139 \mathrm{mg} / \mathrm{kg}$ ). 
Figure 11. Total sulfur in hydraulic oil samples.

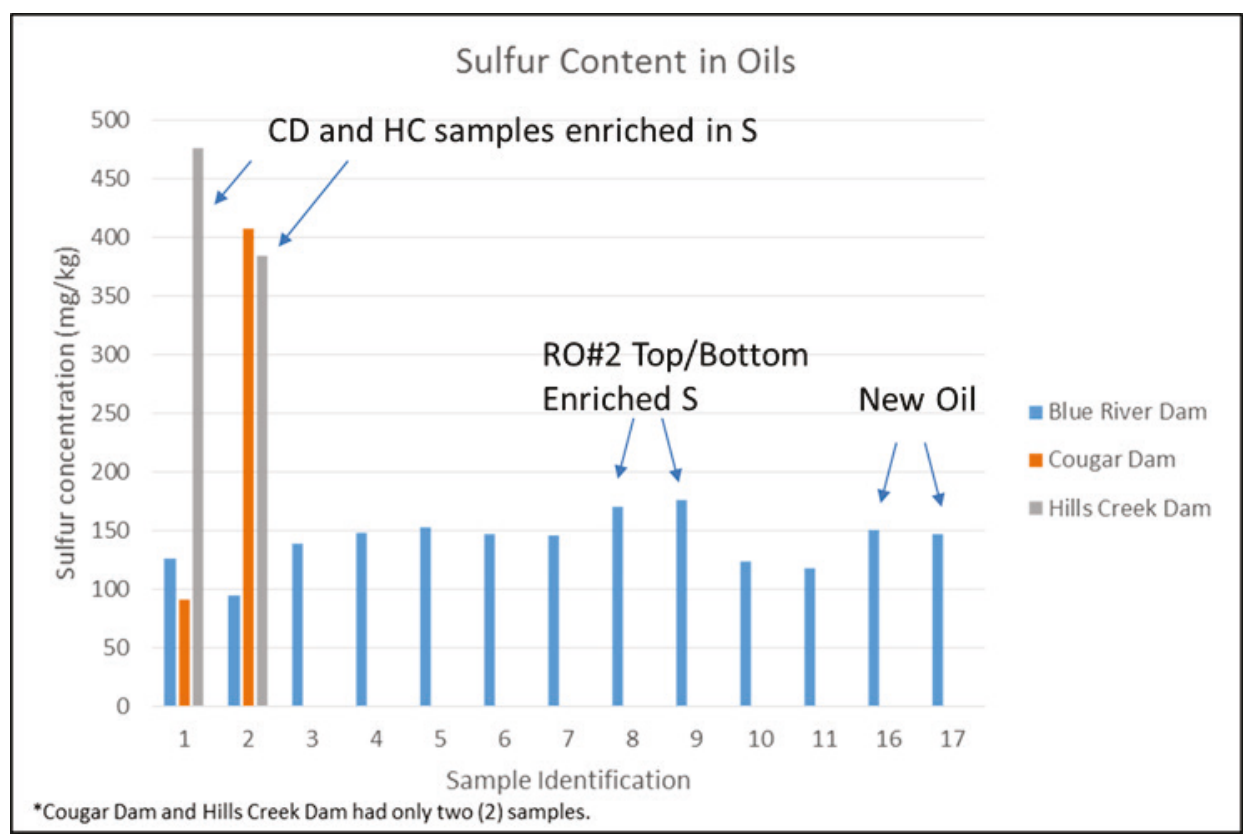

Comparing oil samples to those of the other dams provides some interesting results. Sulfur samples for the oil at Hills Creek Dam were as high as $476 \mathrm{mg} / \mathrm{kg}$, substantially higher than sulfur samples in Blue River samples. Hills Creek does use a different hydraulic oil compared to Blue River and Cougar Dams. Cougar Dam, on the other hand, also used Rando ${ }^{\circledR}$ HD oil. Sample 1 (oil sump tank sample port) had the most depleted sulfur level (90.8 mg/kg). However, sample 2 (oil sump tank drain port) had a very high sulfur level of $407 \mathrm{mg} / \mathrm{kg}$.

\subsubsection{Acid neutralization number}

Figure 12 summarizes the acid neutralization numbers in hydraulic oil samples. The acid neutralization number is used as a measurement of how the oil is aging and oxidizing. Blue River Dam samples acid content ranged from 0.14 to $0.48 \mathrm{mgKOH} / \mathrm{g}$. The new oil (samples 16 and 17) had neutralization numbers of 0.25 and $0.32 \mathrm{mgKOH} / \mathrm{g}$ respectively, nearly a $30 \%$ variation. Therefore, it appears that this measurement does have some inherent variation. Samples 2, 6, 7, 8, 10, and 11 had concentrations ranging from 0.24 to $0.29 \mathrm{mgKOH} / \mathrm{g}$, close to the range of the new oil samples. Samples 3 and 4 were slightly decreased in acid neutralization, both with measurements of $0.23 \mathrm{mgKOH} / \mathrm{g}$. Samples 1 and 4 had more substantial decreases in acid neutralization measurements, both with measurements of $0.14 \mathrm{mgKOH} / \mathrm{g}$. Sample 9 had a highly elevated acid neutralization number of $0.48 \mathrm{mgKOH} / \mathrm{g}$. 
Comparing sample locations 1 and 2 of Blue River Dam acid neutralization numbers to Cougar Dam, indicate the Blue River Dam numbers were slightly less, but samples from both dams had similar concentrations. Both Cougar and Blue River Dams neutralization numbers were higher than those at Hills Creek Dam (note that Hills Creek Dam does use a different hydraulic oil).

Figure 12. Acid neutralization numbers in hydraulic oil samples.

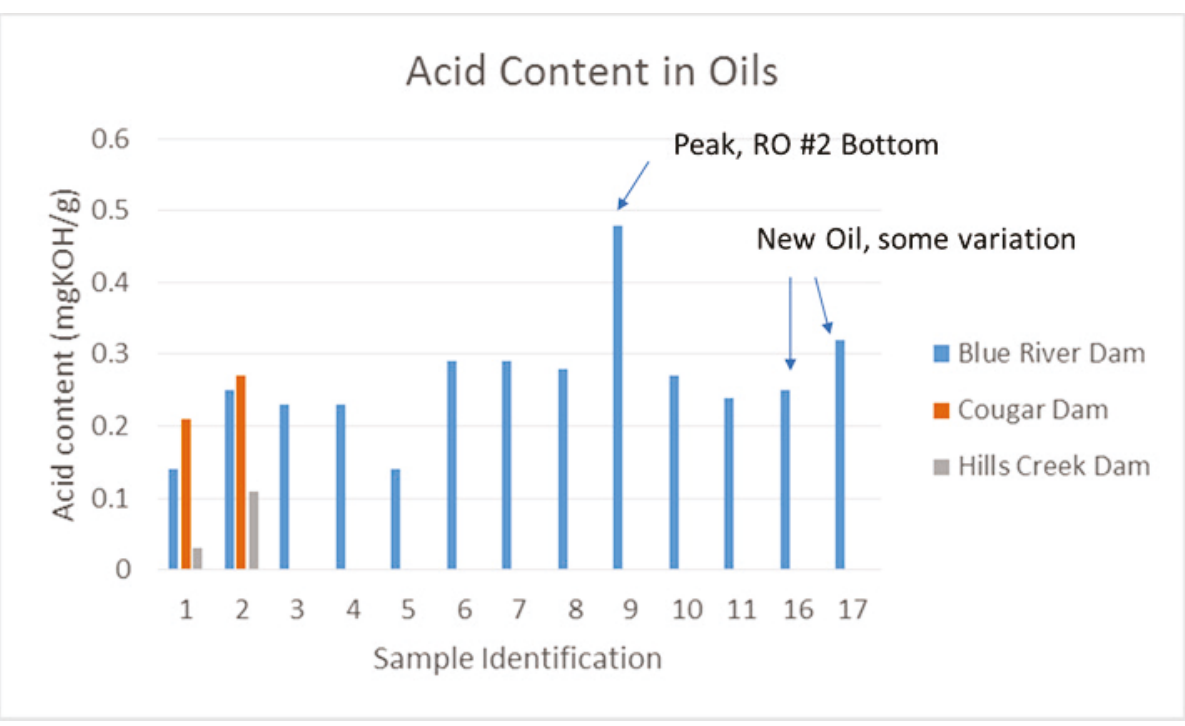

Interestingly, the acid neutralization numbers measured in the study were all high. $0.15 \mathrm{mg} \mathrm{KOH} / \mathrm{g}$ is considered a normal level for most new oils, $0.20 \mathrm{mg} \mathrm{KOH} / \mathrm{g}$ is a warning level that the oil is getting too acidic and $0.30 \mathrm{mg} \mathrm{KOH} / \mathrm{g}$ is a critical warning. However, the new oil samples exceeded the warning level and one actually exceeded the critical level. Most of the samples were higher than $0.2 \mathrm{mg} \mathrm{KOH} / \mathrm{g}$, the warning level.

\subsubsection{Zinc concentration}

Zinc concentrations in Blue River Dam samples ranged from 157 to $420 \mathrm{mg} / \mathrm{kg}$ (Figure 13). The highest concentrations were found in the new oil samples (401 and $420 \mathrm{mg} / \mathrm{kg}$ ). The oil samples collected from the Blue River Dam hydraulic system were all depleted in zinc, with concentrations ranging from 157 to $270 \mathrm{mg} / \mathrm{kg}$. Of the Blue River Dam samples, the highest concentration was found at sample 7, the RO \#1 Emergency bottom.

The Blue River Dam concentrations for sample points 1 and 2 were less than half of those found at Cougar Dam at the same sample points. The Cougar Dam concentrations were comparable to those for the new oil, 
indicating that zinc depletion had not occurred. Hills Creek Dam samples were non-detect (note the Hill Creek Dam hydraulic system uses a different oil that does not contain ZDDP).

Figure 13. Zinc concentration in hydraulic oils in this study.

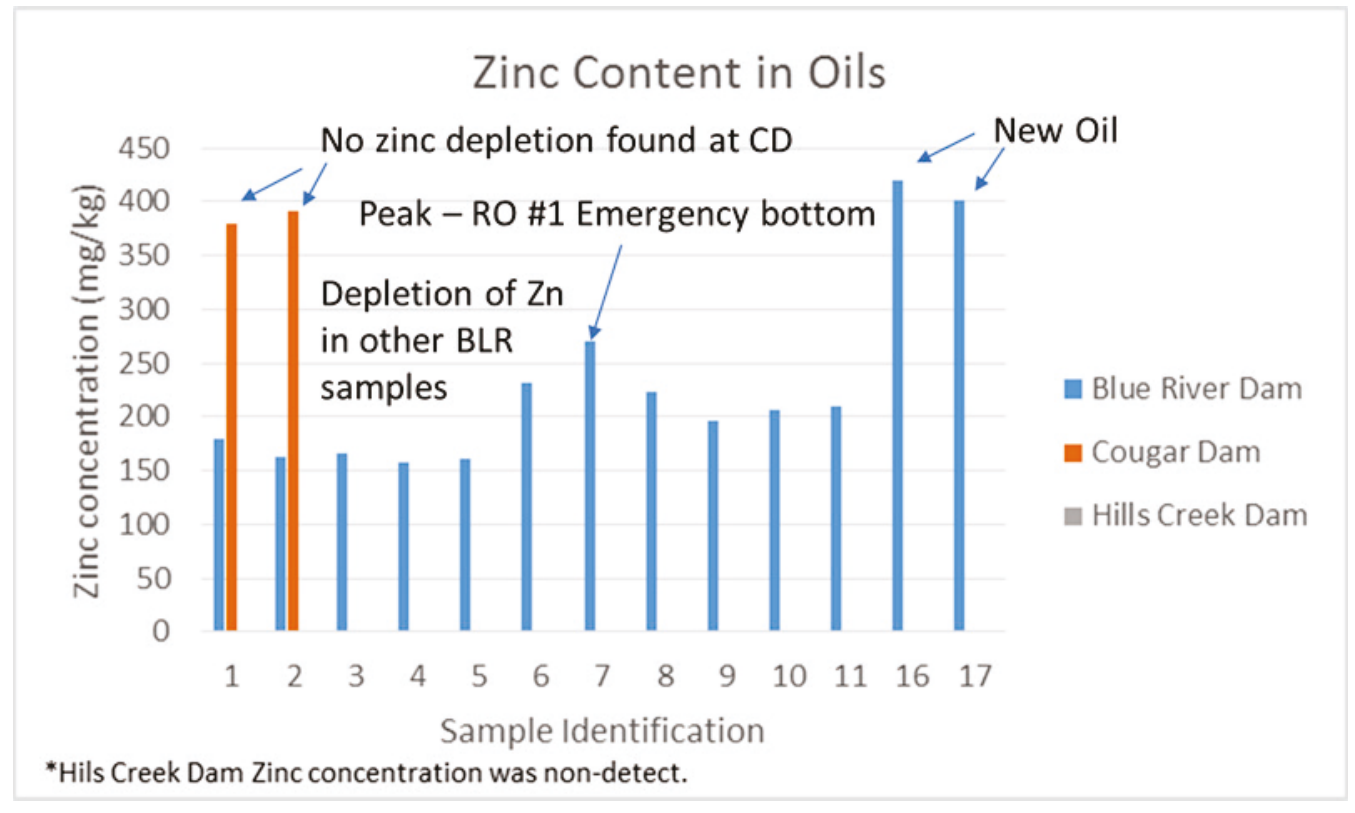

\subsubsection{Percent water in hydraulic oils}

Figure 14 summarizes percent water found in the oil samples collected for this study. The results were heavily skewed by water in the Hills Creek Dam oil samples, these were as high as $45 \%$ (as a side note, this level is extremely high and an investigation is recommended). The picture inset (Figure 14) shows that the water was clearly visible in the oil sample.

The new oil samples had water concentrations of 0.013 and $0.021 \%$. Blue River Dam samples ranged from 0.012 to $0.077 \%$. Water concentrations in the two Cougar Lake Dam samples were 0.056 and $0.169 \%$. 
Figure 14. Percent water in oil samples in the study. The high concentrations in the Hills Creek Dam oil samples dominate the graph. The photo inset shows a separate water phase in one of the Hills Creek Dam samples.

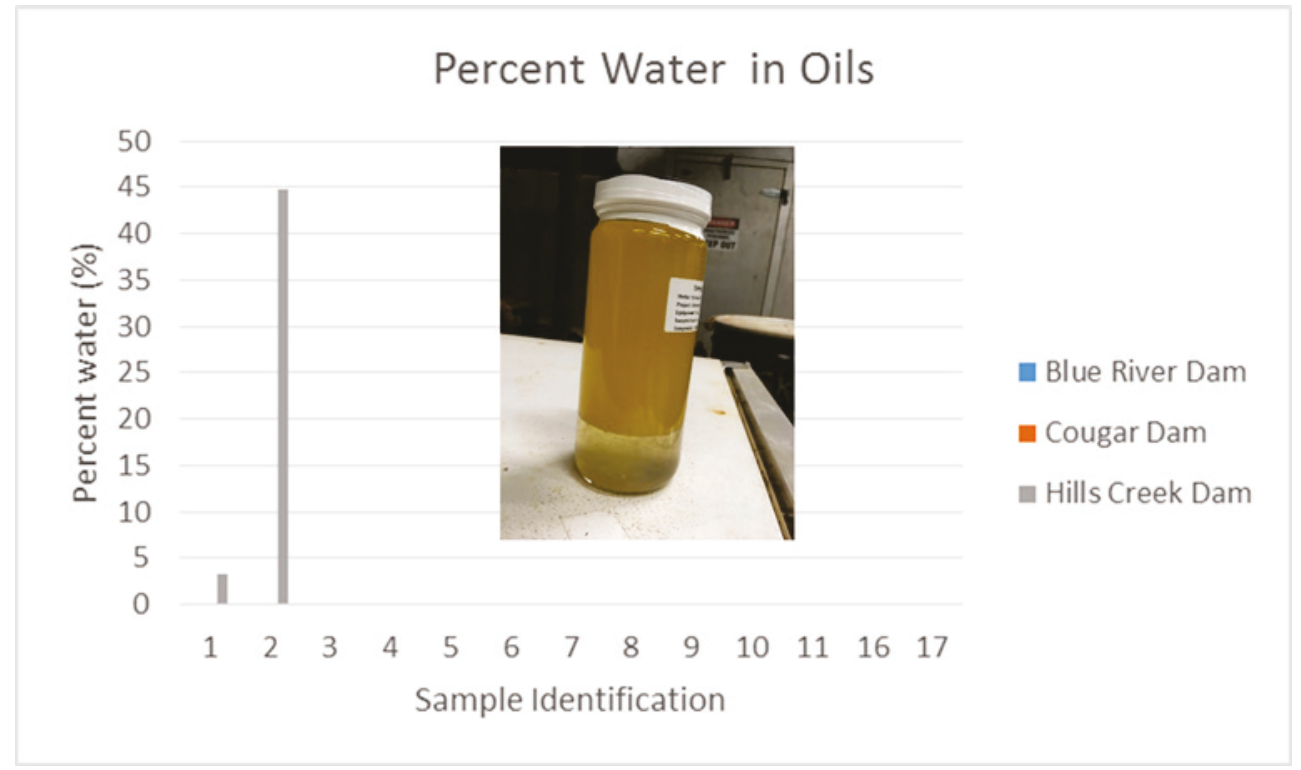

Generally, water content in oils should be kept below 250 ppm, or 0.025\%. Obviously, something very wrong had occurred with the Hills Creek Dam oil samples and they far exceeded this value. Both samples at Cougar Dam also exceeded the threshold (Table 6). At Blue River Dam, four of the thirteen measured samples exceeded this threshold (Table 6).

\subsubsection{Graphs exploring relationships between the oil parameters}

Figures $15-17$ are graphs prepared to explore relationships of water, zinc, and acid number with sulfur in the oil samples. Unfortunately, the data does not lend itself to statistical tests (e.g., t-test or ANOVA) that are focused on determining if a difference between two populations is statistically significant. In this case, graphed data explores if a linear, exponential, or logarithmic relationship between the parameters shows regression, this is an acceptable statistical test. Hills Creek Dam data is included in the graphs (except for the one exploring water content and even though it was a different oil type) so as to increase the total data points in an effort to see a pattern. Unfortunately, no such relations were evident. 
Figure 15. Relationship of percent water and sulfur. (Note, Hill Creek Dam data is not included in the graph because it skewed the graph, but it also did not show an obvious relationship).

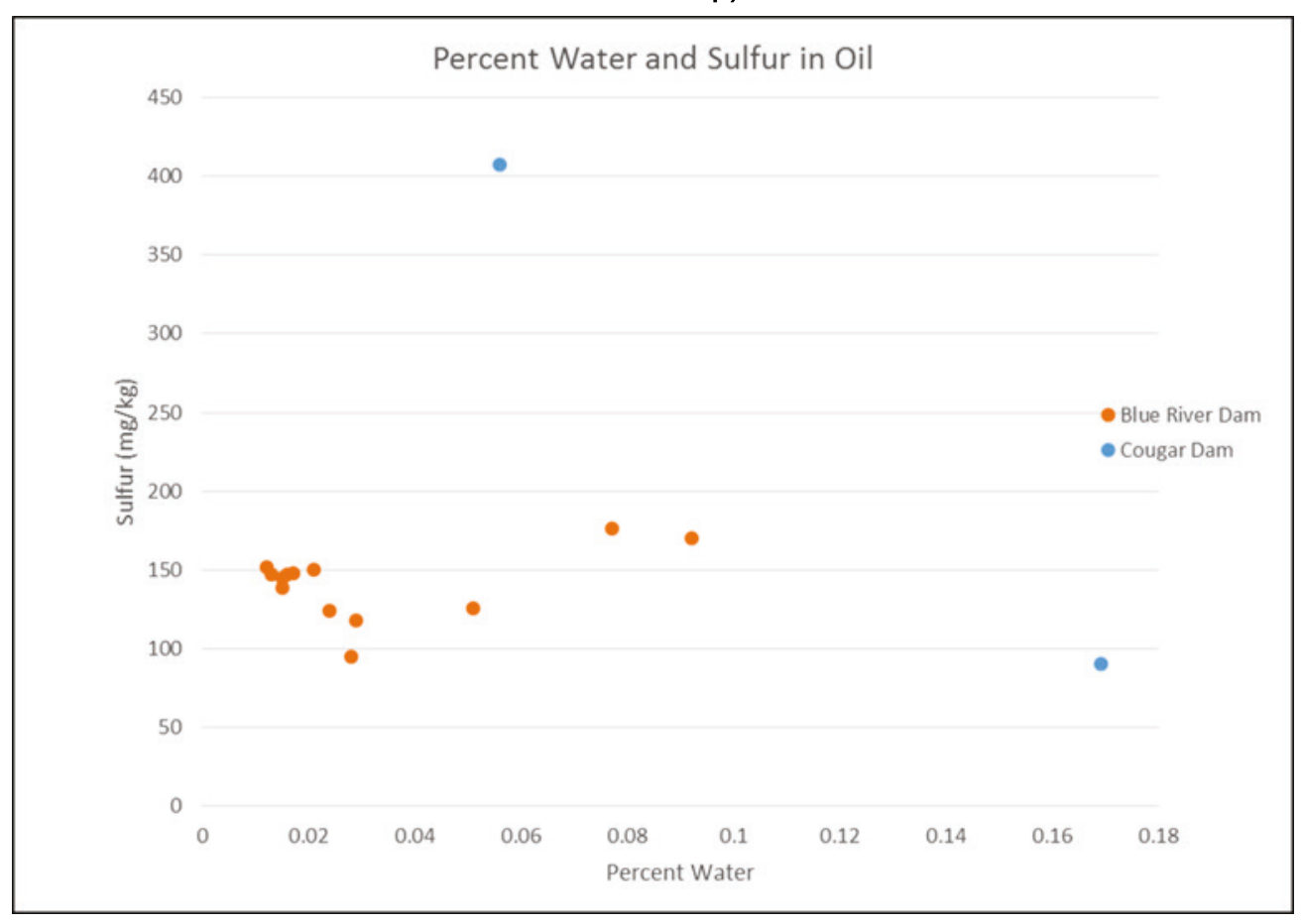

Figure 16. Relationship of zinc concentration and sulfur.

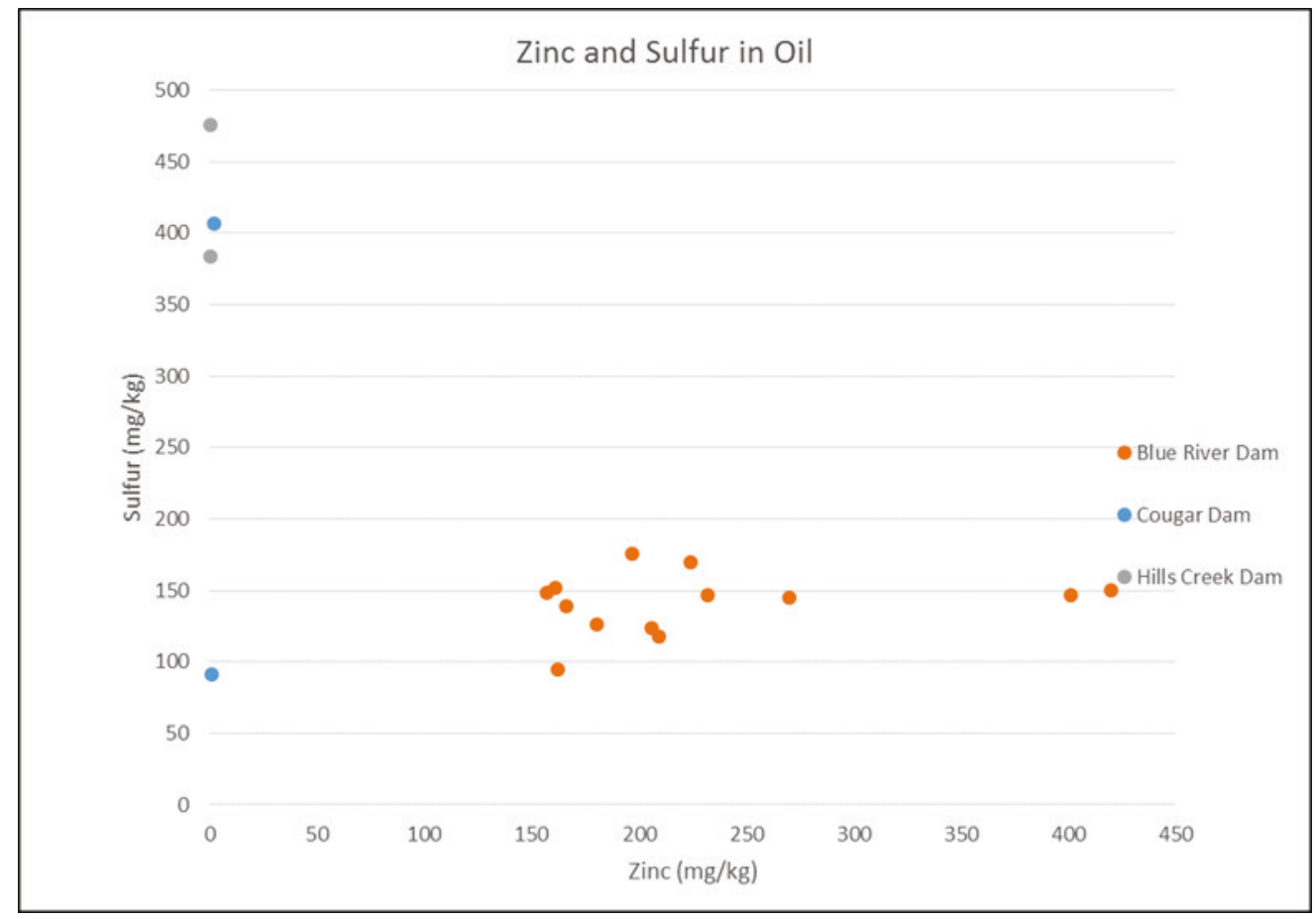


Figure 17. Relationship of acid neutralization number and sulfur.

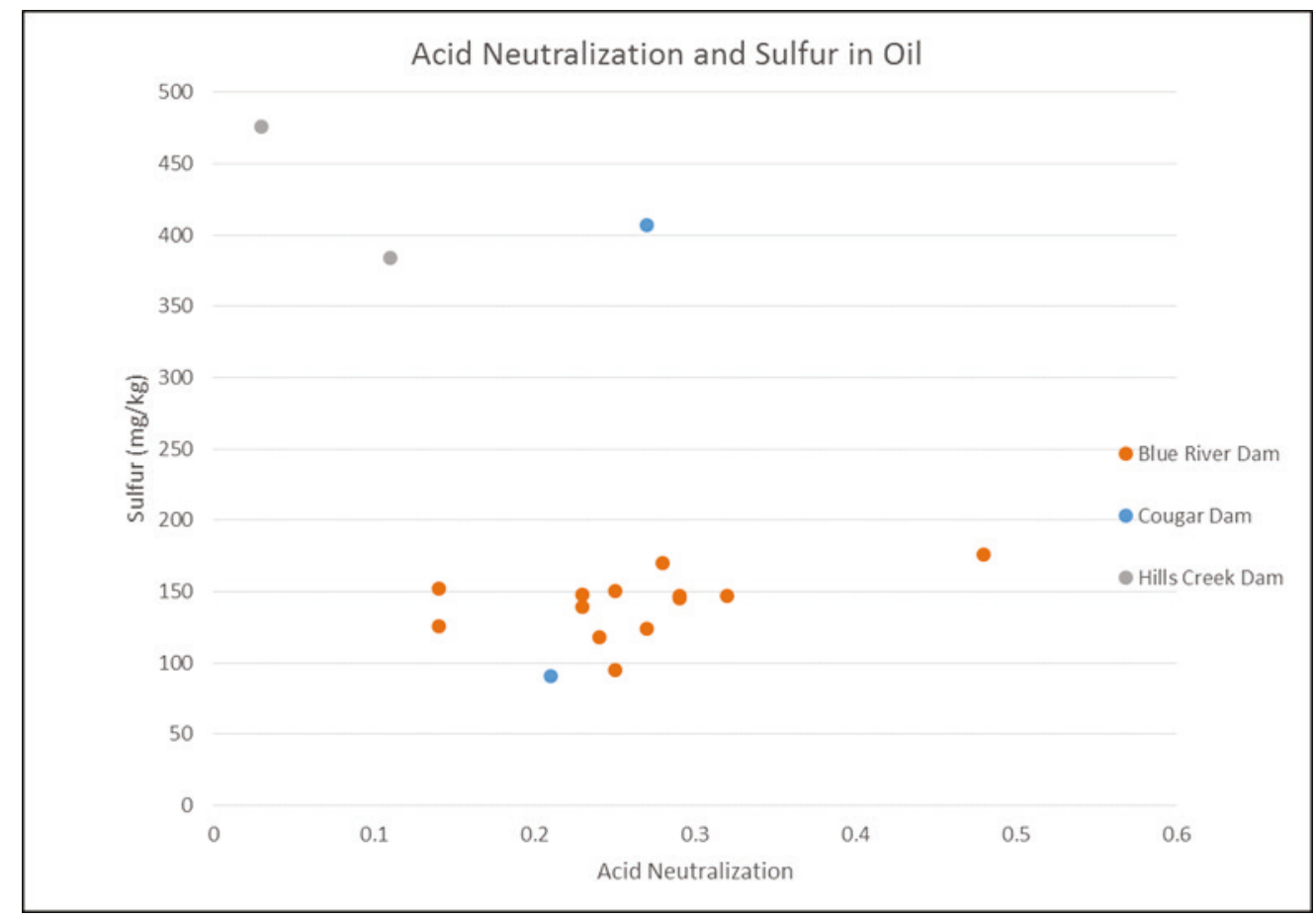

\subsubsection{Water samples}

\subsubsection{Chemical measurements in water samples}

Table 7 summarizes water chemistry from samples collected in the Blue River Dam hydraulic system drainage sump (sample 012) and from the Blue River Dam reservoir (sample 013). Reservoir samples were collected from Cougar Dam (003) and Hills Creek Dam (003). In comparing the reservoir samples, the $\mathrm{pH}$ of the three samples were relatively close, ranging from 7.33 to 7.60. Conductivity measurements had a greater range, with the Blue River Dam sample having the lowest measurement of $30.6 \mathrm{~S} / \mathrm{m}$ and the Hills Creek Dam sample having the highest number of $47.0 \mathrm{~S} / \mathrm{m}$.

The Blue River Dam sump sample had the highest zinc concentration measured at $0.0133 \mathrm{mg} / \mathrm{kg}$. This was higher than zinc levels in the Cougar Dam and Hills Creek Dam sumps (0.0057 and $0.0094 \mathrm{mg} / \mathrm{kg}$ ). The Blue River Dam samples had higher sulfate and sulfur concentrations, however, sulfide was found in Cougar Dam and Hills Creek Dam, but not in Blue River Dam (see section 3.1.2.2 for a more detailed analysis of sulfur measurements). 
The Blue River Dam sump water was higher in $\mathrm{pH}$ (9.82 vs. 7.60) and conductivity (118 vs. $30.6 \mathrm{~S} / \mathrm{m}$ ) compared to the water sample from the Blue River Reservoir. The sump water also had higher sulfate and total sulfur concentrations.

Table 7. Analytical data for water samples.

\begin{tabular}{|c|c|c|c|c|c|c|}
\hline Sample ID & Conductivity $(\mathrm{S} / \mathrm{m})$ & $\mathrm{pH}$ & Sulfate $(\mathrm{mg} / \mathrm{L}$ ) & Sulfide (mg/L) & Sulfur (mg/L) & Zinc (mg/L) \\
\hline Method & EPA 120.1 & EPA 150.1 & EPA 300.0 & EPA 376 & SW 846/6010 & SW 846/6010 \\
\hline \multicolumn{7}{|l|}{ Blue River Dam } \\
\hline BLR-20170126-012 & 118 & 9.82 & 4.08 & $\mathrm{ND}$ & 1.37 & 0.0133 \\
\hline BLR-20170126-013 & 30.6 & 7.60 & 1.50 & $\mathrm{ND}$ & 0.452 & 0.0080 \\
\hline \multicolumn{7}{|l|}{ Cougar Dam } \\
\hline CGR-20170126-003 & 38.2 & 7.33 & 0.316 & 0.0102 & 0.0189 & 0.0057 \\
\hline \multicolumn{7}{|l|}{ Hills Creek Dam } \\
\hline HCR-20170126-003 & 47.0 & 7.37 & 0.426 & 0.0114 & 0.0825 & 0.0094 \\
\hline
\end{tabular}

\subsubsection{Sulfur species}

Sulfate and sulfide were adjusted as $\mathrm{mg} / \mathrm{L}$ as $\mathrm{S}$ to allow direct comparison with total sulfur (Figure 18). Water samples collected from the Blue River Dam site were substantially higher in total sulfur concentrations than those collected from Cougar Dam and Hills Creek Dam. This might be a factor in the sulfide emissions found at Blue River Dam. Sulfur was mostly in the form of sulfate. Some sulfide was found at Cougar Dam and Hills Creek Dam, but not in the Blue River Dam samples.

Figure 18. Comparison of sulfur species in water samples.

Total Sulfur, Sulfate as S, and Sulfide as S in Water Samples

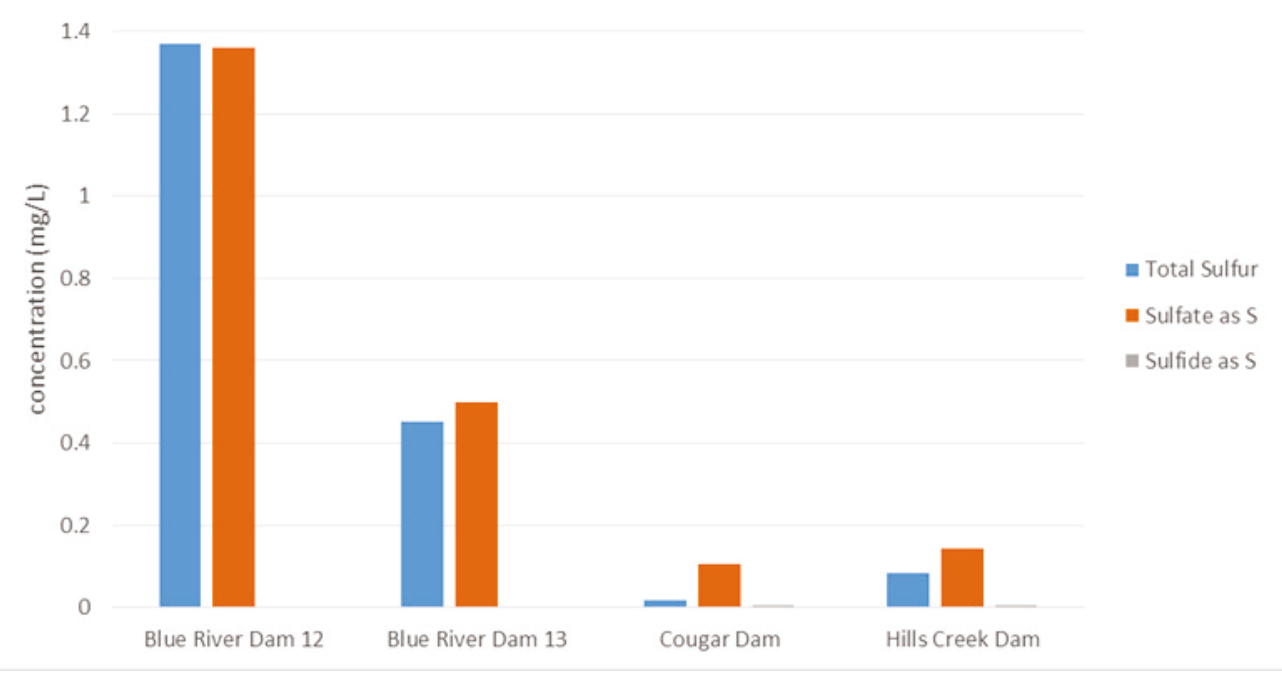




\subsection{Filter study}

\subsubsection{Received filters}

The ERDC received two filters:

- Blue River 014

- Blue River 015

Both were described as original oil filters, and both were relatively clean in appearance (Figure 19).

Figure 19. One of the hydraulic oil system filters received for the study.

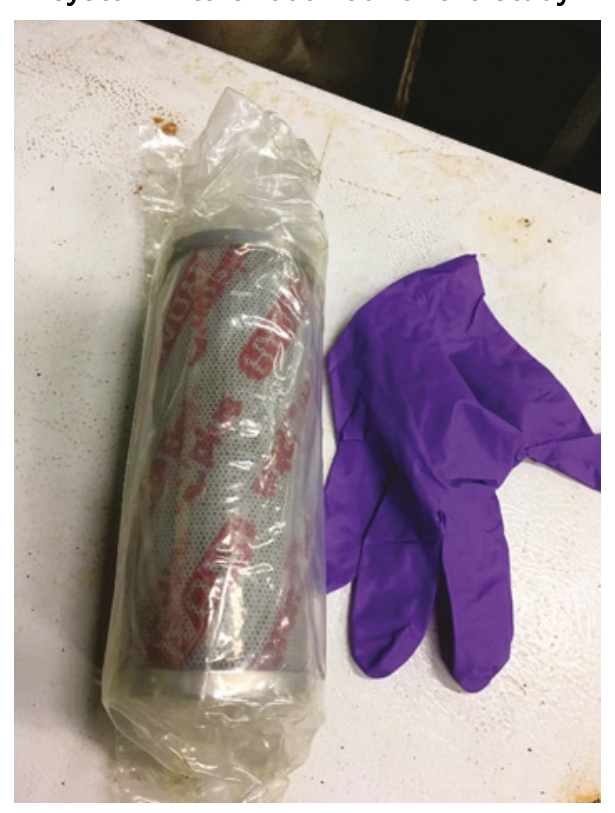

\subsubsection{Filter components}

The filters consisted of five layers (Figure 20):

1. Outer section of large holes in metal housing.

2. A plastic wire mesh.

3. A denser mesh material.

4. A still more dense mesh material.

5. A final material similar in density to layer 3 . 
Figure 20. The five materials found in the hydraulic oil filter.

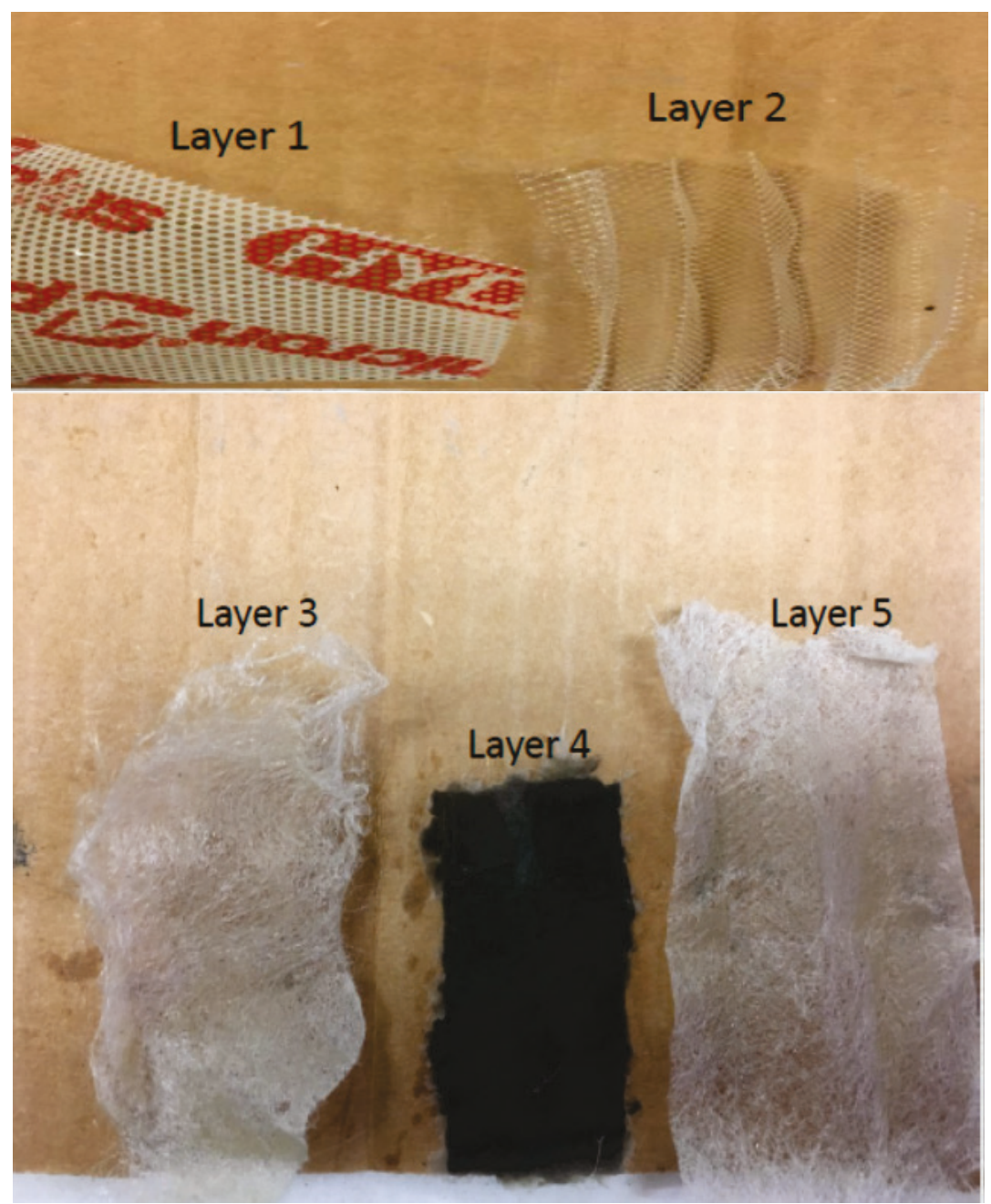

\subsubsection{Observations}

The materials were studied at magnifications ranging from 8 to $100 \mathrm{X}$. Results from filter 014 are shown in Figures 21-25. No evidence of biofilm was observed. Although not shown, observations of filter 015 were identical to those of 014 . 
Figure 21. Magnified view of Layer 1 (8X). No evidence of biological growth.

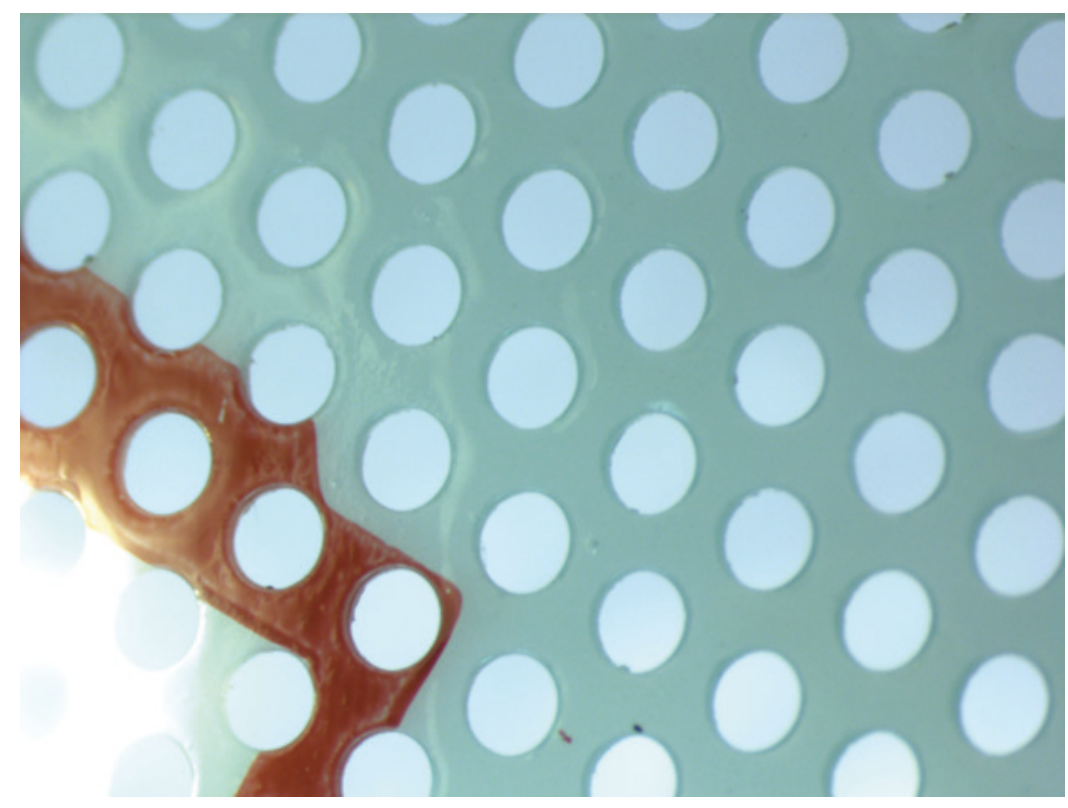

Figure 22. Magnified view of layer 2 (25X). No evidence of biological growth.

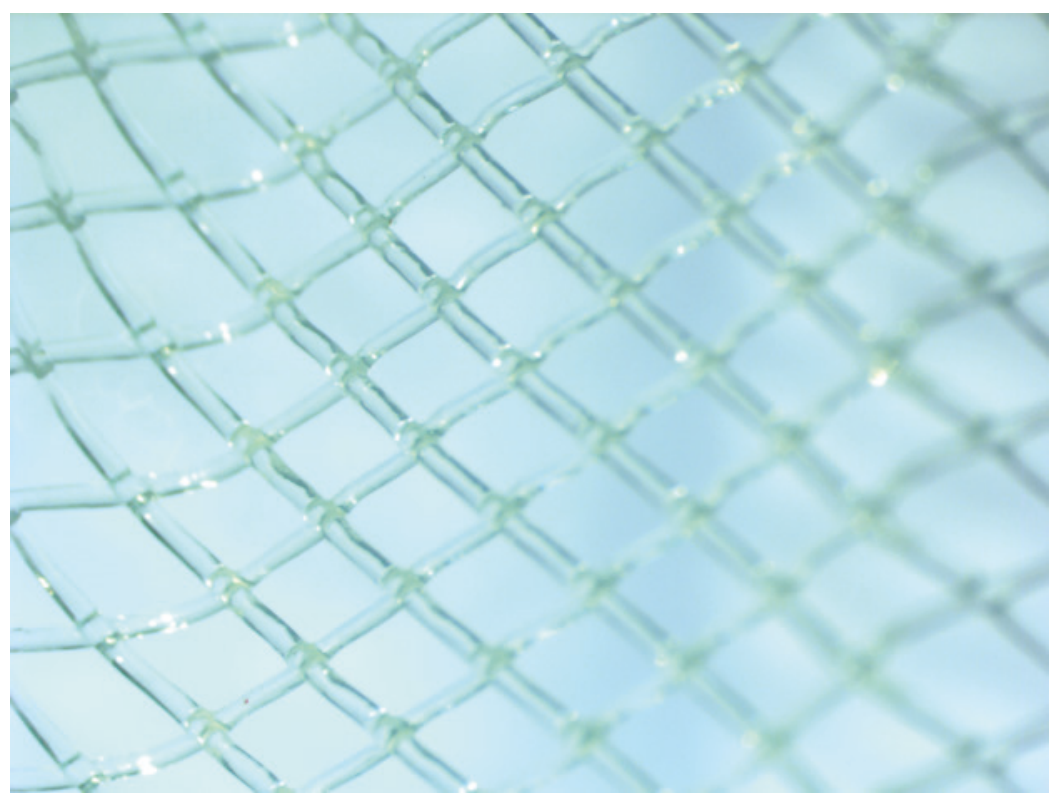


Figure 23. Magnified view of Layer 3 (50X). No evidence of biological growth.

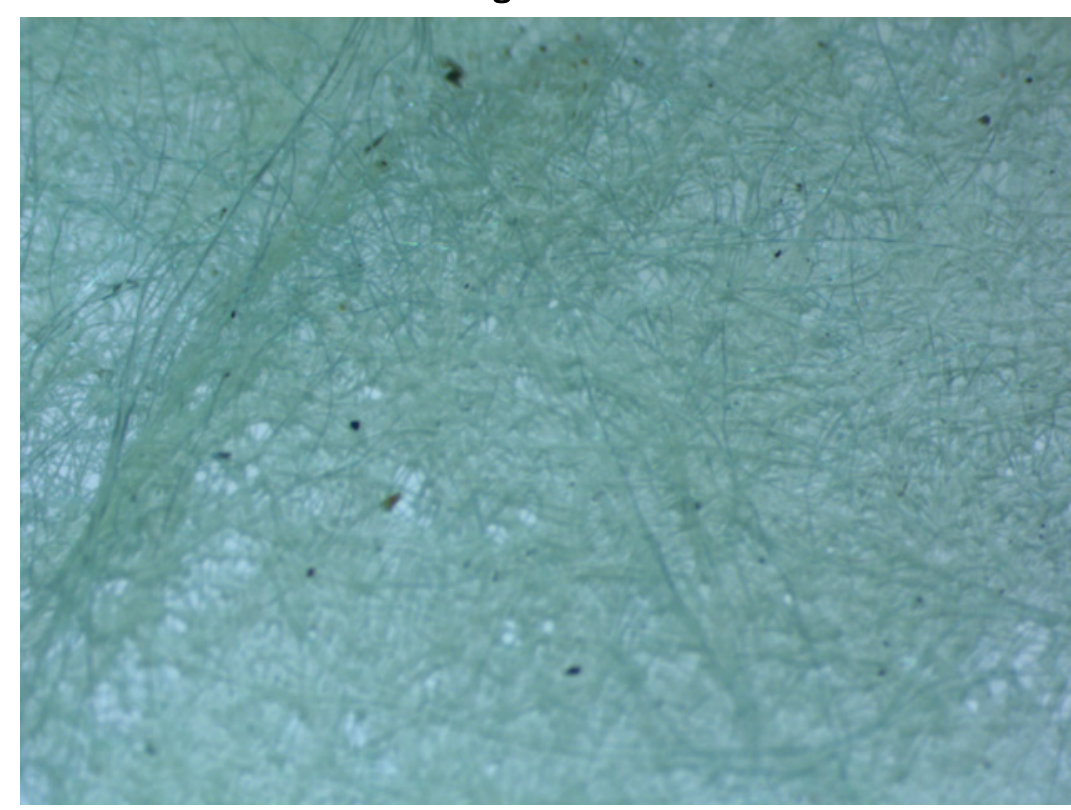

Figure 24. Magnified view of Layer 4 (100X) No evidence of biological growth. 
Figure 25. Magnified view of Layer 5 (50X). No evidence of biological growth.

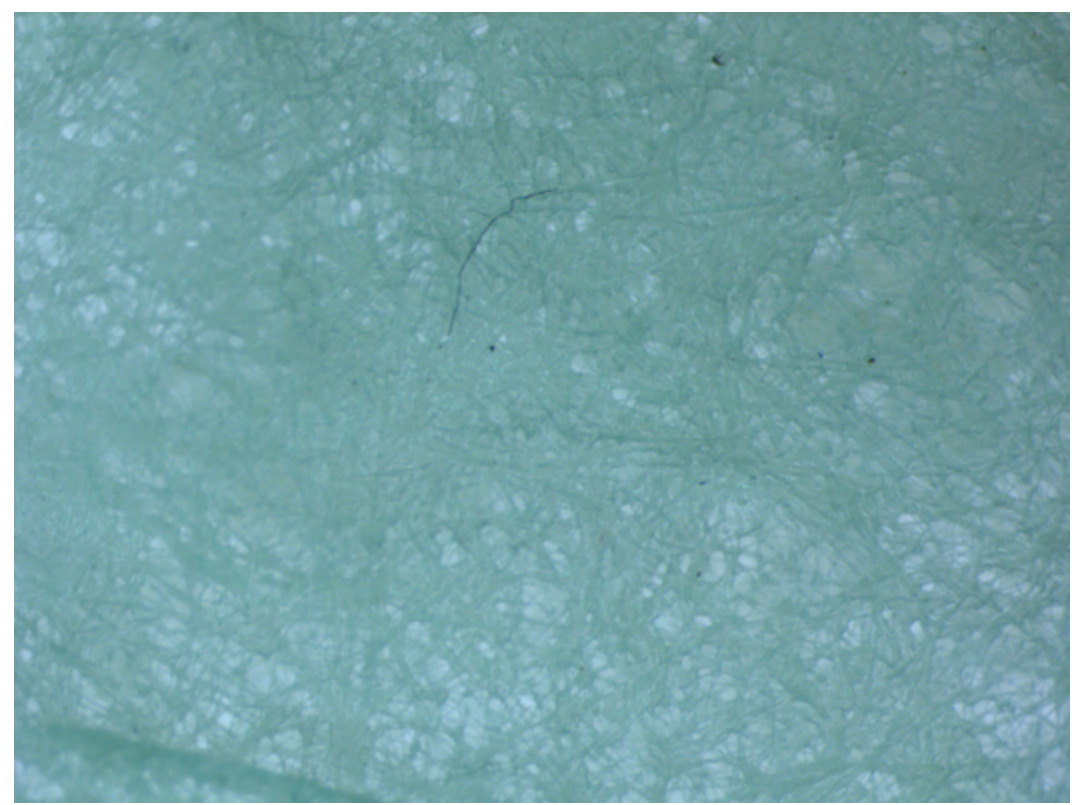

\subsection{Genetic probing of hydraulic oil and water samples}

A complete report on the genetic probe work is attached in Appendix 4. In summary:

- The study included seventeen hydraulic oil and water samples from the three dams.

- Samples were explored using two primers:

○ The first searched for bacterial DNA.

- If the first was positive, then the second searched for genetic material associated with sulfate reducing bacteria.

- Only ten samples showed evidence of bacterial DNA:

- None were found in the new oil samples.

- Positive in water samples for all three dams.

- Five in seventeen oil samples for the Blue River Dam and Hills Creek Dam oil samples.

No evidence was found of sulfate reducing bacteria in either water or oil samples that were taken. 


\section{Discussion}

\subsection{Biological activity}

The focus of this study was to investigate if biological activity was responsible for the hydrogen sulfide production in the Blue River Dam hydraulic system. The results suggest that the hypothesis should be rejected. This study found only minimal markers of biological activity in the hydraulic oil, and none indicating sulfur reducing bacteria (SRB). Also, the study found no evidence of biofilms in the oil filters. Future studies should focus on more detailed sampling from the sump areas where the hydrogen sulfide vapors were first found, perhaps including wipe samples of the sump if feasible. Still, no SRBs were found in the sump samples evaluated in this study.

\subsection{Hydraulic oil measurements}

Even though biological activity was ruled out, studying the hydraulic oil measurements identified some areas of concern and provide data on the possible cause of the sulfide emissions.

\subsubsection{Areas of interest}

In reviewing the hydraulic oil chemistry data, two locations stand out as consistently having values that differ from the new oil, indicating changes to the oil at those locations. They also tend to differ substantially from concentration found in other sample locations. These are the sump and the regulating outlets.

\subsubsection{Sump}

Samples 1 and 2 were collected at the HPU oil sump sample port. Both of these samples had the lowest sulfur measurements and lower zinc concentrations. Sample 1 also had the lowest acid neutralization concentration. Furthermore, the sump tank did appear to be the source of the sulfide vapors during the release event (see section 1, Introduction).

\subsubsection{Regulating outlet samples (RO\#2, top and bottom)}

The RO \# 2 inlet and outlet samples (numbers 8 and 9) had elevated sulfur levels compared to the base oil ( $170 \mathrm{mg} / \mathrm{kg}$ compared to $150 \mathrm{mg} / \mathrm{kg}$ for 
new oil). In addition, sample 9 had the highest acid neutralization number, higher than the new oil samples.

\subsubsection{Zinc}

This study found zinc depletion in the oil samples collected from the Blue River Dam hydraulic system. The new oil samples contained zinc concentrations of 401 and $420 \mathrm{mg} / \mathrm{kg}$, while the zinc concentrations in the hydraulic oil system were lower, 157 to $270 \mathrm{mg} / \mathrm{kg}$. Samples collected from the Cougar Dam hydraulic system, which is similar and uses the same Chevron Rando ${ }^{\circledR}$ oil, had zinc concentrations in the sump slightly lower, but similar to, that of the new oil ( 380 and $392 \mathrm{mg} / \mathrm{kg}$ ). The zinc concentrations in the sump samples at Blue River Dam were 180 and $162 \mathrm{mg} / \mathrm{kg}$.

These results suggest that zinc is depleted over time in the oil. In the Cougar Dam hydraulic system, this depletion is relatively mild, up to $40 \mathrm{mg} / \mathrm{kg}$. However, in the Blue River Dam samples, it was more severe, up to $260 \mathrm{mg} / \mathrm{kg}$. As discussed, zinc is found in the additive ZDDP that is included in the Chevron Rando ${ }^{\circledR}$ oil used at the Blue River Dam. ZDDP is added to the oil to reduce mechanical wear. It is likely that some of the losses of zinc are due to its deposition on surfaces as part of this process (Kopecky 2004). The relatively small losses in zinc concentration found in the Cougar Dam oil is likely due to zinc deposition.

The higher degree of zinc loss in the Blue River Dam oil suggests that another mechanism may be occurring. Zinc does not degrade nor does it commonly form volatile species. The most likely means of zinc loss in the hydraulic oil is through dissolution in water, particularly in the sump. This study found that the water in the Blue River Dam sump had zinc concentrations about three-times higher than those in the Cougar Dam sump.

If the hypothesis that zinc loss in the Blue River Dam oil is due to dissolution in the sump water, then this might also be a mechanism for hydrogen sulfide production. As discussed above in section 1.9.4, ZDDP can form hydrogen sulfide via hydrolysis reactions and these can be enhanced by elevated temperature. The sump was determined to be an area of concern (see section 1.5). A detailed sampling strategy that would include measurements of oil and water volumes could be conducted to allow a detailed mass balance. 


\subsection{Treatments/water removal}

Supplemental water removal systems could be an effective approach to minimize hydrogen sulfide formation. By removing water from the system, then ZDDP hydrolysis reactions should be eliminated. A common approach is called the kidney loop system. In these systems, the fluid is drawn through a water adsorptive media that pulls water out of the oil (Kopecky 2004). This approach is inexpensive and easy to apply, but it is only useful for removing free and emulsified water - it cannot remove dissolved water. Still, free and emulsified water is usually the bulk of the water in the system.

More complete removal can be obtained using vacuum dehydration. These systems use vacuum pressure and condensation to remove free, emulsified, and dissolved water from the hydraulic oil (Figure 26). These systems can also be modified to incorporate sulfide removal. A vacuum system can draw off gas, then react the gas with an iron bed to trap the sulfide as an iron mineral form.

Some other options for water removal include gravity removal (only for free water) and centrifugal systems (free and some emulsified water removal, but not dissolved). Table 8 summarizes several approaches.

Figure 26. A vacuum dehydration hydraulic oil purification system with sulfide removal (High Purity Northwest Inc., www.highpuritynorthwest.com).

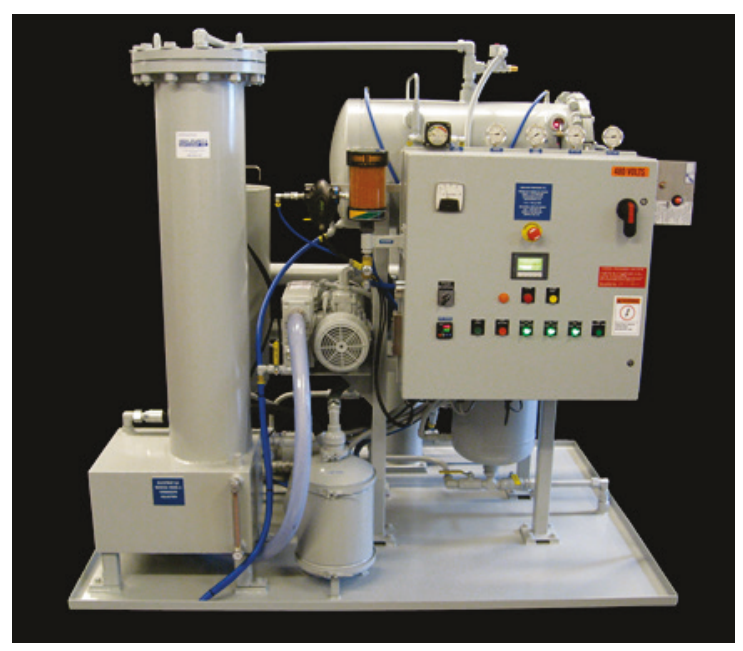


Table 8. Water removal approaches for hydraulic oil (adapted from Kopecky 2004).

\begin{tabular}{|c|c|c|c|}
\hline \multirow{2}{*}{ Separator } & \multicolumn{3}{|c|}{ Water Type Removed } \\
\cline { 2 - 4 } & Free & Emulsified & Dissolved \\
\hline Gravity & Yes & Minimal & No \\
\hline Centrifuge & Yes & Some & No \\
\hline $\begin{array}{c}\text { Absorbing elements } \\
\text { (Kidney loop) }\end{array}$ & Yes & Yes & Yes \\
\hline Vacuum dehydration & Yes & Yes & \\
\hline
\end{tabular}




\section{Conclusions}

Based on this study, the following conclusions can be derived:

\subsection{Sulfur measurements for hydraulic oil}

- No obvious sulfur differences for different hydraulic oil samples collected at Blue River Dam.

- Cougar Dam and Hills Creek Dam samples actually had much higher sulfur than at Blue River Dam. This might indicate that something is occurring at the Blue River Dam resulting in sulfur depletion in the oil.

- Hills Creek Dam had substantially higher percent water than the other sites.

- No obvious relationship with percent water, zinc, or acid neutralization number in relation to sulfur concentrations.

\subsection{Sulfur measurements for water samples}

- Blue River Dam has substantially higher sulfate and sulfur than Cougar River Dam and Hills Creek Dam.

\subsection{Evidence for microbial activity}

- Filter samples were very clean, no evidence of microbial growth.

- Microbial activity is limited in hydraulic oil samples, several showed none.

- No evidence of sulfate reducing bacteria.

\subsection{Conclusion}

- Sulfide production from in the hydraulic oil was most likely abiotic, and most likely due to hydrolysis of ZDDP additive. Also, elevated temperature could play a role.

- Water seepage into the system may be key, providing water for ZDDP reaction. 


\section{Recommendations}

Assuming that a reaction with ZDDP is causing the sulfide release, then the following recommendations are given:

- Focus on Hydrolysis of ZDDP as the most likely cause of $\mathrm{H}_{2} \mathrm{~S}$ emissions.

- Consider replacing hydraulic oil with one that does not contain ZDDP:

- Chevron $\mathrm{AW}^{\circledR}$ is a hydraulic oil with characteristics that indicate that it can be an effective replacement oil (Catherine Campbell, NWP, Appendix 5 contains the product information sheet).

- Chevron $\mathrm{AW}{ }^{\circledR}$ it is not a seamless replacement. It is not compatible with Chevron Rando ${ }^{\circledR}$, and would require a service cleanout.

- Another option would be to identify a suitable Environmentally Acceptable Lubricant (Medina 2015) that reduces issues associated with accident release.

- If it is decided that a ZDDP oil is the best choice, then focus on moisture and temperature control.

- Take actions to ensure that there are no temperature gradients:

* Mixing of temperature sampling well.

* Multiple temperature probes to detect gradients.

- Water control and sulfide removal:

* Use of vacuum dehydration or desiccants (kidney loop) to remove water from system.

* Consider an integrated system that also removes sulfide.

- Use caution when servicing the system in the future:

* Follow confined space working procedures.

* Breathing protection or ventilation.

* Monitoring equipment for sulfide gas.

- Consider laboratory studies to explore conditions where hydrolysis reactions occurs:

* Vary temperature, pressure, water quantity, external sulfur, oil age.

* Consider a study to conduct a detailed mass balance of zinc in the system.

* The ERDC can design and execute such a study. 


\section{References}

American Chemistry Council (ACC). 2015. Safe Handling Guidelines for ZDDP Components and Blends. Washington, D.C. https://www.americanchemistry.com/ProductsTechnology/Petroleum-Additives-Safety-TaskGroup-PAST/Safe-Handling-Guidelines-for-ZDDP-Components-and-Blends.pdf. (Accessed on 26 December 2017).

Crocker, D. 2016. Oil: The Unknown Hazard. US Army Corps of Engineers, Portland District. Presentation Slides.

Kopecky, E. Z. 2004. "Water in hydraulic oil - its effect and control." Науковий вісник. 14(3):83-89.

Lipus, Daniel, Amit Vikram, Daniel Ross, Daniel Bain, Djuna Gulliver, Richard Hammack, and Kyle Bibby. 2017. "Predominance and metabolic potential of halanaerobium spp. in produced water from hydraulically fractured marcellus shale wells.” Applied and Environmental Microbiology 83(8):e02659-16.

Marriott, Robert A., Payman Pirzadeh, Juan Marrugo-Hernandez, and Shaunak Raval. 2015. "Hydrogen sulfide formation in oil and gas." Canadian Journal of Chemistry 94:406-413.

Medina, Victor, F. 2015. Evaluation of environmentally acceptable lubricants (EALs) for dams management by the U.S. Army Corps of Engineers. Vicksburg: MS. U.S. Army Engineer Research and Development Center Technical Note. ERDC-TNWQTN-MS-9. http://acwc.sdp.sirsi.net/client/en_US/search/asset/1045297.

Nicholson, Mike, and Tim O'Brien. 2001. Hydrogen sulfide in petroleum. Baker Petrolite Corporation. Presentation Slides. http://www.coga-inc.org/docs/default-source/meetingpresentations/20010531H2S.pdf (Accessed on 26 December 2017).

National Institute of Occupational Safety and Health (NIOSH). 2005. NIOSH Pocket Guide to Chemical Hazards, third printing. DHHS (NIOSH) Publication 2005149. https://www.cdc.gov/niosh/docs/2005-149/pdfs/2005-149.pdf. (Accessed on 26 December 2017). 


\section{Appendix A: Project Notes (Provided by Catherine Campbell, NWP)}

COMMENTS WELCOME!!! I used Track Changes in minutes below to show changes due to today's discussion.

***WE EXPECT TO BE ALLOWED TO FINISH LAB TESTING BEFORE

FINALIZING BOI***

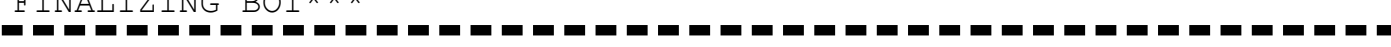

We know the H2S is in the oil, because the oil sample, and the breather on the sump tank [See "Isometric and Photos.pdf"], peg the H2S meter at $100 \mathrm{ppm}$. Could not get H2S to register on the meter anywhere else in the tower. Also, interviews led us to believe the Project personnel were most strongly affected when the pump motor blowers were blowing air from the sump breather into their faces.

What caused the H2S?

It could have been the oil itself: Hydraulic oils have widely varying amounts of sulfur, depending on API grade. Grade I can have up to 8000 PPM, but grades II and III have less than 10 PPM. The sulfur is released as H2S when water contamination reacts with the sulfur compounds. Solubility of H2S in oil is "low" but not zero, actual quantified solubility is highly dependent on temperature and Henry's Law constant in relation to the specific hydraulic oil.

It could have been the reservoir water: Sulfur-reducing bacteria, which use sulfur as an energy source, are the primary producers of large quantities of hydrogen sulfide. These bacteria chemically change natural sulfates in water to hydrogen sulfide. Sulfur-reducing bacteria live in oxygen-deficient environments such as deep reservoirs. It is formed from decomposing underground deposits of organic matter such as decaying plant material, and may flourish with heat.

But it was probably the interaction of an additive called ZDDP with water AND/OR WITH HEAT: ZDDP can produce H2S when 
stored too hot, and though the temperature of the sump at the site visit was about 30 degrees Fahrenheit lower than the long-term heat threshold I found online, the temperature on the surface of the heating element may be above that threshold. This will be looked into further in-house. [See "Safe-Handling-Guidelines-for-ZDDP-Components-and-Blends.pdf"] Hydraulic fluid will typically contain ZDDP (Zinc dialkyldithiophosphate) as an antiwear (and somewhat of an anti-oxidant) additive. I CALLED CHEVRON AND THE "RANDO HD” oil definitely has ZDDP in it. ZDDP content is quite high as an additive, typically ranging from 100 to 1000 ppm. Any compounds with "thio" in the name contain sulfur. Some hydraulic oils are non-zinc in order to protect the copper alloy components. Testing with a lab such as would be needed to verify zinc and sulfur content of new oil identical to that in the system. A spectrochemical analysis would help with that.

ZDDP + Water $=>$ H2S + Sulfuric Acid [See "ZDDP Molecule.pdf" and "Kopecky Article.pdf"]

ZDDP is very sensitive to breakdown in the presence of free water. IF water levels are elevated it will break down and H2S is one of the potential byproducts. Water content above 300 ppm is problematic, and anything above 100 ppm should be viewed with suspicion. The recent test results show very low water content [See "Previous Lab Test Results.pdf], but the procedure for drawing a sample for testing is to clean/dry it FIRST, so the test results may not fairly represent the state the oil "dwells" in most of the time. High acid numbers may be an indication that oxidation due to high water content over time has occurred.

But why would HEAT AND/OR water + ZDDP have created this issue ONLY at Blue River? Alan has looked into possible paths for reservoir water to get into the cylinders and it does not look at all likely - it seems the water must have been ambient and entered the sump through the breather. Why not at Cougar, where acid number results are also high? Why not at Hills Creek, where water in the oil is known to be an issue? Let's test several samples in several ways to be sure. [See "ERDC ESTIMATE WITH TRACK CHANGES - Sulfide in Hydraulic Systems Outline_11042016.docx" and "Hydraulic Fluid Testing.msg"]

THIS IS A TOTAL OF 3 WATER SAMPLES + 18 OIL SAMPLES (1/2 liter, glass containers) + FILTERS TO ERDC ALTOGETHER, all on "ice".

From Blue River: 
- Check the water for sulfur-reducing organisms and for sulfide and sulfate, $\mathrm{pH}$, and zinc.

- Check 11 oil samples for water, zinc, sulfur, acid number, and sulfurreducing organisms

- Sample already taken that is pegging the meter

- Samples from tops and bottoms of all 4 cylinders

- Fresh sample from sump tank sample port

- Sample from sump tank drain port - SPECIFICALLY ASK WHETHER WATER IS VISIBLE TO THE NAKED EYE IN THIS SAMPLE.

- Directly examine filter scrapings under microscope

From Cougar, which is very similar to Blue River, with the same oil, perhaps even from the same "batch" of oil, and is also known to have high acid number results. Cougar also has a heater on the sump tank.:

- Check the water for sulfur-reducing organisms and for sulfide and sulfate, $\mathrm{pH}$, and zinc.

- Check 2 oil samples for water, zinc, sulfur, acid number, and sulfurreducing organisms

○ From sump tank sample port

- From sump tank drain port - SPECIFICALLY ASK WHETHER WATER IS VISIBLE TO THE NAKED EYE IN THIS SAMPLE.

From Hills Creek, which is NOT similar to Blue River:

- Check the water for sulfur-reducing organisms and for sulfide and sulfate, $\mathrm{pH}$, and zinc.

- Check 2 oil samples for water, zinc, sulfur, acid number, and sulfurreducing organisms

- From sump tank sample port

- From sump tank drain port - SPECIFICALLY ASK WHETHER WATER IS VISIBLE TO THE NAKED EYE IN THIS SAMPLE.

From NEW Chevron Rando HD 32 oil [See "Chevron Rando HD32.pdf"] in Project's possession:

- Check for water, zinc, sulfur, acid number, and sulfur-reducing organisms

From NEW Chevron Clarity Hydraulic AW 32 oil [See "Chevron Clarity AW.pdf"] NOT in Project's possession, but Project can get some:

- Check for water, zinc, sulfur, acid number, and sulfur-reducing organisms

From NEW Chevron Hydraulic Oil AW 32 [See "Chevron Hydraulic Oil AW.pdf"] in Project's possession:

- Check for water, zinc, sulfur, acid number, and sulfur-reducing organisms 
If we are agreed on the above, what do we do about it right now?

- $\quad$ Rich and April are working to determine/procure needed hardware to attach to existing ports to take samples.

- Dave will be able to get KTR in to take samples, and can provide sample bottles, and shipment "on ice" to ERDC.

- Glass bottles, $1 / 2$ liter,

- Ask Victor for revised estimate, MIPR \$, and "go"? We do get to continue on the $\mathrm{BO}$ team through lab test results and finalizing path forward once we have that data. YAY! Discussed verbal estimate was that ERDC/lab work could be done in January.

\section{Ultimate Path Forward, to be modified if test results lead to other conclusions:}

\section{Get rid of Blue River's in-service hydraulic oil:}

- Using KTR in SCBA gear, hazardous waste disposal, etc.?

- Using equipment such as High Purity NorthWest's kidney-loop vacuum dehydrator WITH H2S REMOVAL system - apparently the dehydrator, instead of venting gas to the room, sends it through an additional filter that renders the H2S inert - "turns it to rust". [See "Oil Purification.msg"] They can put one together that can go down the manlift. One of these could be used as an additional "normal" kidney-loop but could also go all over the District in case someone else runs into $\mathrm{H} 2 \mathrm{~S}$ in the future. Then personnel perhaps without SCBA, but with ventilation \& monitoring just in case, could remove oil as normal?

- Either way, wipe down accessible wetted surfaces with lint-free cloths.

\section{Replace hydraulic oil:}

- With new oil, but the same type already in use.

- With NEW new oil - that has no ZDDP in it at all - such as Chevron Clarity Hydraulic AW 32 oil. This would be Incompatible with Rando HD oil, so system would need to be flushed at least twice with the new oil before the final fill. It may or may not be incompatible with Chevron Hydraulic Oil AW - Cathy will call Chevron to ask.

\section{Keep it very dry AND MAYBE COOLER:}

- Dedicate kidney loop?

- Increase frequency of breather replacement

- REPLACE HEATER OR REDUCE TEMPERATURE SETTING? 


\section{Appendix B: Product Data Sheet (PDS) and MSDS for Chevron-Rando Oil ${ }^{\circledR}$}




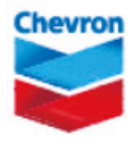

\section{RANDO ${ }^{\circledR} \mathrm{HD}$ \\ $10,22,32,46,68,100,150,220,320$}

\section{PRODUCT DESCRIPTION}

Rando $\odot$ HD oils are formulated with premium base oil technology and designed to give robust protection to hydraulic pumps in mobile and stationary systems.

\section{CUSTOMER BENEFITS}

Rando $H D$ oils deliver value through:

- Long equipment life - Special antiwear additive package minimizes wear by protecting surfaces when load causes breakdown of the lubricant film.

- Minimized downtime - Effective rust and oxidation inhibitor system helps prevent the production of abrasive particles from rust formation. and deposits, varnishes and sludges from oil breakdown, which can damage equipment surfaces and seals, and block filters prematurely.

- Smooth operation - Good hydrolytic stability and water separation characteristics promote excellent filterability in the presence of water contamination. Good anti-foam and air release help ensure smooth operation and system efficiency.

- Optimal oil service life - High oxidation stability resists oil thickening and deposit formation in service, minimizing the possibility of an unscheduled change of hydraulic fluid.

\section{FEATURES}

Rando HD ISO 32, 46, and 68 are formulated with Group II base stocks.

Rando HD ISO 100, 150, 220, and 320 are designed for lubricant applications requiring an AGMA $R \& O$ gear oil lubricant in the applicable viscosity grade.

Rando HD oils provide excellent:

- antiwear protection

- oxidation and corrosion inhibition
- foam and aeration suppression

Under moderate loads and temperatures, the high viscosity index of Rando HD oils help ensure good film strength between metal surfaces and is further enhanced by antiwear additive protection.

\section{APPLICATIONS}

Rando HD ISO 10 and 22 can be used as spindle lubricants where zinc-free oils are not a requirement.

Rando HD ISO 32, 46, or 68 are recommended for:

- vane-, piston-, or gear-type pumps, especially where pressures exceed 1000 psi

- lightly loaded reciprocating compressors

Rando HD ISO 100, 150, 220, or 320 are recommended for applications where AGMA rust and oxidation inhibited oils are required:

- hydraulic equipment reduction gears where EP is not required

- plain and antifriction bearings

- circulating oil systems

Rando HD oils are approved for:

- Eaton-Vickers 35VQ25A pump, M-2950-S (Mobile) and 1-286-S (Stationary) (ISO 32, 46, 68)

- Fives Cincinnati (formerly MAG Cincinnati, Cin Machine, Cin Milacron) P-68 (ISO 32), P-70 (ISO 46), P-69 (ISO 68)

- Parker Hannifin (Denison) HFO, HF1, HF2, T6H2OC (ISO 32, 46, 68)

Rando HD oils meet the requirements of:

- AFNOR NF E 48-603 HM (ISO 32, 46, 68)

- ANSI/AGMA 9005-E02, Industrial Gear Lubrication, for gear lubrication as rust and oxidation inhibited gear oils (1SO 46, 68, 100, 150, 220)

Product(s) manufactured in the USA, Colombia and El Salvador. Always confirm that the product selected is consistent with the original equipment manufacturer's recommendation for the equipment operating conditions and customer's maintenance practices.

A Chevron company product

Q 2008-2016 Chevron U.S.A. Inc. All rights reserved. chevron, the Chevron Hallmark and Rando are trademarks owned by Chevron Intelectual Property $L C$. All othes trademarks are property of their respective owners. 
- ASTM D6158 hM (ISO 32, 46, 68, 100, 150)

- Bosch Rexroth former specification RE 90220-01 (ISO 32, 46, 68)

- DIN 51524-2 (ISO 32, 46, 68)

- General Motors LS2 Specification, LH for antiwear hydraulic fluids (ISO 32, 46, 68)

- ISO 11158 L-HM

- Joy HO-S (ISO 68)

- US Steel 126, 127 (ISO 32, 46, 68)
Rando HD 32, 46, 68, 100, 150, 220, 320 are

registered by NSF and are acceptable as lubricants

where there is no possibility of food contact (H2) in and around food processing areas. The NSF Nonfood

Compounds Registration Program is a continuation of

the USDA product approval and listing program, which

is based on meeting regulatory requirements of

appropriate use, ingredient review and labeling

verification.

Do not use in high pressure systems in the vicinity of flames, sparks and hot surfaces. Use only in well ventilated areas. Keep container closed.

Do not use in breathing air apparatus or medical equipment.

\section{TYPICAL TEST DATA}

\begin{tabular}{|c|c|c|c|c|c|}
\hline ISO Grade & 10 & 22 & 32 & 46 & 68 \\
\hline Product Number & 273252 & 273276 & 273277 & 273278 & 273279 \\
\hline $\begin{array}{l}\text { SDS/MSDS Number } \\
\text { USA } \\
\text { Colombia } \\
\text { El Salvador }\end{array}$ & $\begin{array}{c}23706 \\
- \\
-\end{array}$ & $\begin{array}{c}23548 \\
- \\
-\end{array}$ & $\begin{array}{l}23556 \\
33476 \\
33477\end{array}$ & $\begin{array}{l}23556 \\
33476 \\
33477\end{array}$ & $\begin{array}{l}23556 \\
33476 \\
33477\end{array}$ \\
\hline AGMA Grade & - & - & - & 1 & 2 \\
\hline API Gravity & 27.7 & 33.7 & 32.6 & 31.8 & 31.6 \\
\hline $\begin{array}{l}\text { Viscosity, Kinematic } \\
\text { CSt at } 40^{\circ} \mathrm{C} \\
\text { CSt at } 100^{\circ} \mathrm{C}\end{array}$ & $\begin{array}{c}10.3 \\
2.5\end{array}$ & $\begin{array}{c}23.1 \\
4.4\end{array}$ & $\begin{array}{c}30.4 \\
5.2\end{array}$ & $\begin{array}{c}43.7 \\
6.5\end{array}$ & $\begin{array}{c}64.6 \\
8.4\end{array}$ \\
\hline $\begin{array}{l}\text { Viscosity, Saybolt } \\
\text { SUS at } 100^{\circ} \mathrm{F} \\
\text { SUS at } 210^{\circ} \mathrm{F}\end{array}$ & $\begin{array}{l}63 \\
35\end{array}$ & $\begin{array}{c}120 \\
41\end{array}$ & $\begin{array}{c}157 \\
44\end{array}$ & $\begin{array}{r}225 \\
48\end{array}$ & $\begin{array}{c}334 \\
54\end{array}$ \\
\hline Viscosity Index & 48 & 98 & 99 & 97 & 98 \\
\hline Flash Point, ${ }^{\circ} \mathrm{C}\left({ }^{\circ} \mathrm{F}\right)$ & $154(309)$ & $177(351)$ & $220(428)$ & $226(439)$ & $235(455)$ \\
\hline Pour Point, ${ }^{\circ} \mathrm{C}\left({ }^{\circ} \mathrm{F}\right)$ & $-39(-38)$ & $-36(-33)$ & $-33(-27)$ & $-30(-22)$ & $-30(-22)$ \\
\hline $\begin{array}{l}\text { Oxidation Stability } \\
\text { Hours to } 2.0 \mathrm{mg} \mathrm{KOH} / \mathrm{g} \text { acid number, } \\
\text { ASTM D943 }\end{array}$ & - & - & $>5000$ & $>5000$ & $>5000$ \\
\hline
\end{tabular}

Minor variations in product typical test data are to be expected in normal manufacturing. 
Rando ${ }^{\circledR}$ HD - Continued

\section{TYPICAL TEST DATA}

\begin{tabular}{|l|c|c|c|c|}
\hline ISO Grade & $\mathbf{1 0 0}$ & $\mathbf{1 5 0}$ & $\mathbf{2 2 0}$ & $\mathbf{3 2 0}$ \\
\hline \hline Product Number & 273228 & 273280 & 273281 & 277316 \\
\hline $\begin{array}{l}\text { SDS/MSDS Number } \\
\text { USA } \\
\text { Colombia } \\
\text { El Salvador }\end{array}$ & 23550 & 23550 & 23550 & 23550 \\
\hline AGMA Grade & 33474 & 33474 & - & - \\
\hline API Gravity & 33475 & 33475 & - & - \\
\hline $\begin{array}{l}\text { Viscosity, Kinematic } \\
\text { cSt at } 40^{\circ} \mathrm{C}\end{array}$ & 3 & 4 & 5 & 6 \\
CSt at $100^{\circ} \mathrm{C}$ & 30.1 & 29.7 & 28.5 & 27.4 \\
\hline $\begin{array}{l}\text { Viscosity, Saybolt } \\
\text { SUS at } 100^{\circ} \mathrm{F} \\
\text { SUS at } 210^{\circ} \mathrm{F}\end{array}$ & 95.0 & 143 & 209 & 304 \\
\hline Viscosity Index & 11.0 & 14.2 & 13.2 & 23.4 \\
\hline Flash Point, ${ }^{\circ} \mathrm{C}\left({ }^{\circ} \mathrm{F}\right)$ & 495 & 751 & 1105 & 1617 \\
\hline Pour Point, ${ }^{\circ} \mathrm{C}\left({ }^{\circ} \mathrm{F}\right)$ & 64 & 76 & 93 & 117 \\
\hline Oxidation Stability \\
$\quad \begin{array}{l}\text { Hours to } 2.0 \mathrm{mg} \mathrm{KOH} / \mathrm{g} \text { acid number, } \\
\text { ASTM D943 }\end{array}$ & 100 & 97 & 96 & 96 \\
\hline
\end{tabular}

Minor variations in product typical test data are to be expected in normal manufacturing. 


\section{Safety Data Sheet}

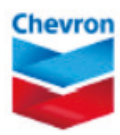

SECTION 1 PRODUCT AND COMPANY IDENTIFICATION

Rando HD 32, 46, 68

Product Use: Hydraulic Oil

Product Number(s): 273277, 273278, 273279

Company Identification

Chevron Products Company

a division of Chevron U.S.A. Inc.

6001 Bollinger Canyon Rd.

San Ramon, CA 94583

United States of America

www.chevronlubricants.com

Transportation Emergency Response

CHEMTREC: (800) $424-9300$ or (703) $527-3887$

Health Emergency

Chevron Emergency Information Center: Located in the USA. International collect calls accepted. (800)

$231-0623$ or $(510) 231-0623$

Product Information

email : lubemsds@chevron.com

Product Information: 1 (800) 582-3835, LUBETEK@chevron.com

SECTION 2 HAZARDS IDENTIFICATION

CLASSIFICATION: Not classified as hazardous according to 29 CFR 1910.1200 (2012).

HAZARDS NOT OTHERWISE CLASSIFIED: Not Applicable

Revision Date: FEBRUARY 05, 2016

1 of $9 \quad$ Rando HD $32,46,68$

SDS : 23556 
SECTION 3 COMPOSITION/ INFORMATION ON INGREDIENTS

\begin{tabular}{|l|l|l|}
\hline COMPONENTS & CAS NUMBER & AMOUNT \\
\hline Highly refined mineral oil (C15-C50) & Mixture & $70-99 \%$ weight \\
\hline
\end{tabular}

SECTION 4 FIRST AID MEASURES

Description of first aid measures

Eye: No specific first aid measures are required. As a precaution, remove contact lenses, if worn, and flush eyes with water.

Skin: No specific first aid measures are required. As a precaution, remove clothing and shoes if contaminated. To remove the material from skin, use soap and water. Discard contaminated clothing and shoes or thoroughly clean before reuse.

Ingestion: No specific first aid measures are required. Do not induce vomiting. As a precaution, get medical advice.

Inhalation: No specific first aid measures are required. If exposed to excessive levels of material in the air, move the exposed person to fresh air. Get medical attention if coughing or respiratory discomfort occurs.

Most important symptoms and effects, both acute and delayed IMMEDIATE HEALTH EFFECTS

Eye: Not expected to cause prolonged or significant eye irritation.

Skin: Contact with the skin is not expected to cause prolonged or significant irritation. Contact with the skin is not expected to cause an allergic skin response. Not expected to be harmful to internal organs if absorbed through the skin. High-Pressure Equipment Information: Accidental high-velocity injection under the skin of materials of this type may result in serious injury. Seek medical attention at once should an accident like this occur. The initial wound at the injection site may not appear to be serious at first; but, if left untreated, could result in disfigurement or amputation of the affected part.

Ingestion: Not expected to be harmful if swallowed.

Inhalation: Not expected to be harmful if inhaled. Contains a petroleum-based mineral oil. May cause respiratory irritation or other pulmonary effects following prolonged or repeated inhalation of oil mist at airborne levels above the recommended mineral oil mist exposure limit. Symptoms of respiratory irritation may include coughing and difficulty breathing.

\section{DELAYED OR OTHER HEALTH EFFECTS: Not classified}

Indication of any immediate medical attention and special treatment needed Note to Physicians: In an accident involving high-pressure equipment, this product may be injected under the skin. Such an accident may result in a small, sometimes bloodless, puncture wound. However, because of its driving force, material injected into a fingertip can be deposited into the palm of the hand. Within 24 hours, there is usually a great deal of swelling, discoloration, and intense throbbing pain. Immediate treatment at a surgical emergency center is recommended.

Revision Number: 6

Revision Date: FEBRUARY 05, 2016
2 of 9

Rando HD 32, 46, 68

SDS : 23556 


\section{SECTION 5 FIRE FIGHTING MEASURES}

EXTINGUISHING MEDIA: Use water fog, foam, dry chemical or carbon dioxide (CO2) to extinguish flames.

Unusual Fire Hazards: Leaks/ruptures in high pressure system using materials of this type can create a fire hazard when in the vicinity of ignition sources (eg. open flame, pilot lights, sparks, or electric arcs).

PROTECTION OF FIRE FIGHTERS:

Fire Fighting Instructions: This material will burn although it is not easily ignited. See Section 7 for proper handling and storage. For fires involving this material, do not enter any enclosed or confined fire space without proper protective equipment, including self-contained breathing apparatus.

Combustion Products: Highly dependent on combustion conditions. A complex mixture of airborne solids, liquids, and gases including carbon monoxide, carbon dioxide, and unidentified organic compounds will be evolved when this material undergoes combustion.

\section{SECTION 6 ACCIDENTAL RELEASE MEASURES}

Protective Measures: Eliminate all sources of ignition in vicinity of spilled material.

Spill Management: Stop the source of the release if you can do it without risk. Contain release to prevent further contamination of soil, surface water or groundwater. Clean up spill as soon as possible, observing precautions in Exposure Controls/Personal Protection. Use appropriate techniques such as applying non-combustible absorbent materials or pumping. Where feasible and appropriate, remove contaminated soil. Place contaminated materials in disposable containers and dispose of in a manner consistent with applicable regulations.

Reporting: Report spills to local authorities and/or the U.S. Coast Guard's National Response Center at (800) 424-8802 as appropriate or required.

\section{SECTION 7 HANDLING AND STORAGE}

General Handling Information: Avoid contaminating soil or releasing this material into sewage and drainage systems and bodies of water.

Precautionary Measures: DO NOT USE IN HIGH PRESSURE SYSTEMS in the vicinity of flames, sparks and hot surfaces. Use only in well ventilated areas. Keep container closed.

Static Hazard: Electrostatic charge may accumulate and create a hazardous condition when handling this material. To minimize this hazard, bonding and grounding may be necessary but may not, by themselves, be sufficient. Review all operations which have the potential of generating and accumulating an electrostatic charge and/or a flammable atmosphere (including tank and container filling, splash filling, tank cleaning, sampling, gauging, switch loading, filtering, mixing, agitation, and vacuum truck operations) and use appropriate mitigating procedures.

Container Warnings: Container is not designed to contain pressure. Do not use pressure to empty container or it may rupture with explosive force. Empty containers retain product residue (solid, liquid, and/or vapor) and can be dangerous. Do not pressurize, cut, weld, braze, solder, drill, grind, or expose

Revision Number: 6

Revision Date: FEBRUARY 05, 2016
3 of 9

Rando HD 32, 46, 68 SDS : 23556 
such containers to heat, flame, sparks, static electricity, or other sources of ignition. They may explode and cause injury or death. Empty containers should be completely drained, properly closed, and promptly returned to a drum reconditioner or disposed of properly.

\section{SECTION 8 EXPOSURE CONTROLS/PERSONAL PROTECTION}

GENERAL CONSIDERATIONS:

Consider the potential hazards of this material (see Section 2), applicable exposure limits, job activities, and other substances in the work place when designing engineering controls and selecting personal protective equipment. If engineering controls or work practices are not adequate to prevent exposure to harmful levels of this material, the personal protective equipment listed below is recommended. The user should read and understand all instructions and limitations supplied with the equipment since protection is usually provided for a limited time or under certain circumstances.

ENGINEERING CONTROLS:

Use in a well-ventilated area.

PERSONAL PROTECTIVE EQUIPMENT

Eye/Face Protection: No special eye protection is normally required. Where splashing is possible, wear safety glasses with side shields as a good safety practice.

Skin Protection: No special protective clothing is normally required. Where splashing is possible, select protective clothing depending on operations conducted, physical requirements and other substances in the workplace. Suggested materials for protective gloves include: $4 \mathrm{H}$ (PEEVAL), Nitrile Rubber, Silver Shield, Viton.

Respiratory Protection: No respiratory protection is normally required.

If user operations generate an oil mist, determine if airborne concentrations are below the occupational exposure limit for mineral oil mist. If not, wear an approved respirator that provides adequate protection from the measured concentrations of this material. For air-purifying respirators use a particulate cartridge. Use a positive pressure air-supplying respirator in circumstances where air-purifying respirators may not provide adequate protection.

Occupational Exposure Limits:

\begin{tabular}{|l|l|l|l|l|l|}
\hline Component & Agency & TWA & STEL & Ceiling & Notation \\
\hline $\begin{array}{l}\text { Highly refined mineral oil (C15- } \\
\text { C50) }\end{array}$ & OSHA Z-1 & $5 \mathrm{mg} / \mathrm{m} 3$ & - & - & - \\
\hline $\begin{array}{l}\text { Highly refined mineral oil (C15- } \\
\text { C50) }\end{array}$ & ACGIH & $5 \mathrm{mg} / \mathrm{m} 3$ & $10 \mathrm{mg} / \mathrm{m} 3$ & - & - \\
\hline
\end{tabular}

Consult local authorities for appropriate values.

SECTION 9 PHYSICAL AND CHEMICAL PROPERTIES

Revision Number: 6

Revision Date: FEBRUARY 05, 2016
4 of 9

Rando HD 32, 46, 68

SDS : 23556 
Skin Sensitization: The skin sensitization hazard is based on evaluation of data for product components. Acute Dermal Toxicity: The acute dermal toxicity hazard is based on evaluation of data for product components.

Acute Oral Toxicity: The acute oral toxicity hazard is based on evaluation of data for product components. Acute Inhalation Toxicity: The acute inhalation toxicity hazard is based on evaluation of data for product components.

Acute Toxicity Estimate: Not Determined

Germ Cell Mutagenicity: The hazard evaluation is based on data for components or a similar material.

Carcinogenicity: The hazard evaluation is based on data for components or a similar material.

Reproductive Toxicity: The hazard evaluation is based on data for components or a similar material.

Specific Target Organ Toxicity - Single Exposure: The hazard evaluation is based on data for components or a similar material.

Specific Target Organ Toxicity - Repeated Exposure: The hazard evaluation is based on data for components or a similar material.

ADDITIONAL TOXICOLOGY INFORMATION:

This product contains petroleum base oils which may be refined by various processes including severe solvent extraction, severe hydrocracking, or severe hydrotreating. None of the oils requires a cancer warning under the OSHA Hazard Communication Standard (29 CFR 1910.1200). These oils have not been listed in the National Toxicology Program (NTP) Annual Report nor have they been classified by the International Agency for Research on Cancer (IARC) as; carcinogenic to humans (Group 1), probably carcinogenic to humans (Group 2A), or possibly carcinogenic to humans (Group 2B).

These oils have not been classified by the American Conference of Governmental Industrial Hygienists $(A C G I H)$ as: confirmed human carcinogen (A1), suspected human carcinogen (A2), or confirmed animal carcinogen with unknown relevance to humans (A3).

SECTION 12 ECOLOGICAL INFORMATION

ECOTOXICITY

This material is not expected to be harmful to aquatic organisms.

The product has not been tested. The statement has been derived from the properties of the individual components.

MOBILITY

No data available.

Revision Number: 6

Revision Date: FEBRUARY 05, 2016
6 of 9

Rando HD 32, 46, 68 SDS: 23556 
PERSISTENCE AND DEGRADABILITY

This material is not expected to be readily biodegradable. The biodegradability of this material is based on an evaluation of data for the components or a similar material.

The product has not been tested. The statement has been derived from the properties of the individual components.

POTENTIAL TO BIOACCUMULATE

Bioconcentration Factor: No data available.

Octanol/Water Partition Coefficient: No data available

SECTION 13 DISPOSAL CONSIDERATIONS

Use material for its intended purpose or recycle if possible. Oil collection services are available for used oil recycling or disposal. Place contaminated materials in containers and dispose of in a manner consistent with applicable regulations. Contact your sales representative or local environmental or health authorities for approved disposal or recycling methods.

\section{SECTION 14 TRANSPORT INFORMATION}

The description shown may not apply to all shipping situations. Consult $49 C F R$, or appropriate Dangerous Goods Regulations, for additional description requirements (e.g., technical name) and mode-specific or quantity-specific shipping requirements.

DOT Shipping Description: NOT REGULATED AS A HAZARDOUS MATERIAL UNDER 49 CFR

IMO/IMDG Shipping Description: NOT REGULATED AS DANGEROUS GOODS FOR TRANSPORT UNDER THE IMDG CODE

ICAO/IATA Shipping Description: NOT REGULATED AS DANGEROUS GOODS FOR TRANSPORT UNDER ICAO

Transport in bulk according to Annex II of MARPOL $73 / 78$ and the IBC code: Not applicable

SECTION 15 REGULATORY INFORMATION

2. Delayed (Chronic) Health Effects: NO

3. Fire Hazard: NO

4. Sudden Release of Pressure Hazard: NO

5. Reactivity Hazard: NO

Revision Number: 6

7 of 9

Rando HD 32, 46, 68

Revision Date: FEBRUARY 05, 2016

SDS : 23556 
REGULATORY LISTS SEARCHED

01-1=IARC Group $1 \quad$ 03=EPCRA 313

01-2A=IARC Group 2A 04=CA Proposition 65

01-2B=|ARC Group $2 B \quad$ 05=MA RTK

02=NTP Carcinogen 06=NJ RTK

$07=P A$ RTK

No components of this material were found on the regulatory lists above.

CHEMICAL INVENTORIES:

All components comply with the following chemical inventory requirements: AICS (Australia), DSL (Canada), ENCS (Japan), IECSC (China), KECl (Korea), PICCS (Philippines), TSCA (United States).

NEW JERSEY RTK CLASSIFICATION

Under the New Jersey Right-to-Know Act L. 1983 Chapter 315 N.J.S.A. 34:5A-1 et. seq., the product is to be identified as follows: PETROLEUM OIL (Hydraulic oil)

SECTION 16 OTHER INFORMATION

NFPA RATINGS: Health: 0 Flammability: 1 Reactivity: 0

HIMIS RATINGS: Health: 0 Flammability: 1 Reactivity: 0

(0-Least, 1-Slight, 2-Moderate, 3-High, 4-Extreme, PPE:- Personal Protection Equipment Index

recommendation, *-Chronic Effect Indicator). These values are obtained using the guidelines or published

evaluations prepared by the National Fire Protection Association (NFPA) or the National Paint and Coating Association (for HMIS ratings).

REVISION STATEMENT: This revision updates the following sections of this Safety Data Sheet: $1-16$ Revision Date: FEBRUARY 05, 2016

ABBREVIATIONS THAT MAY HAVE BEEN USED IN THIS DOCUMENT:

\begin{tabular}{|l|l|}
\hline TLV - Threshold Limit Value & TWA - Time Weighted Average \\
\hline STEL - Short-term Exposure Limit & PEL - Permissible Exposure Limit \\
\hline GHS - Globally Harmonized System & CAS - Chemical Abstract Service Number \\
\hline $\begin{array}{l}\text { ACGIH - American Conference of Governmental } \\
\text { Industrial Hygienists }\end{array}$ & $\begin{array}{l}\text { IMO/IMDG - International Maritime Dangerous Goods } \\
\text { Code }\end{array}$ \\
\hline API - American Petroleum Institute & SDS - Safety Data Sheet \\
\hline HMIS - Hazardous Materials Information System & NFPA - National Fire Protection Association (USA) \\
\hline DOT - Department of Transportation (USA) & NTP - National Toxicology Program (USA) \\
\hline IARC - International Agency for Research on & OSHA - Occupational Safety and Health Administration
\end{tabular}

Revision Number: 6

8 of 9

Revision Date: FEBRUARY 05, 2016
Rando HD 32, 46, 68

SDS : 23556 


\begin{tabular}{|l|l|} 
Cancer & \\
\hline NCEL - New Chemical Exposure Limit & EPA - Environmental Protection Agency \\
\hline SCBA - Self-Contained Breathing Apparatus & \\
\hline
\end{tabular}

Prepared according to the 29 CFR 1910.1200 (2012) by Chevron Energy Technology Company, 6001

Bollinger Canyon Road San Ramon, CA 94583.

The above information is based on the data of which we are aware and is believed to be correct as of the date hereof. Since this information may be applied under conditions beyond our control and with which we may be unfamiliar and since data made available subsequent to the date hereof may suggest modifications of the information, we do not assume any responsibility for the results of its use. This information is furnished upon condition that the person receiving it shall make his own determination of the suitability of the material for his particular purpose. 


\title{
Appendix C: Quality Assurance Plan
}

\author{
Quality Assurance Project Plan
}

"Blue River Study - Investigation of Sulfide in Hydraulic Oil"

Prepared by the U.S. Army Corps of Engineers

January 28 to March 22, 2017 


\section{SECTION 1.0 BACKGROUND}

\subsection{Purpose of the Study}

Recently, hydrogen sulfide emissions were found during the maintenance of a hydraulic system at the Blue River, Cougar, and Hills Creek Dam. Hydrogen sulfide is potentially toxic and explosive. So, determining the cause of this gas is needed. There are three possibilities - thermal transformation of ZDDP (a sulfur containing additive to the hydraulic oil), abiotic hydrolysis reaction of the ZDDP, or microbially mediated reduction of sulfur. ERDC will support the Portland District (NWP) with studies to explore sulfide in the oil and associated water. We will also look for evidence of sulfur reduction by microbial activity. These studies coupled with studies to be conducted by NWP should allow for us to narrow down the possible causes of this sulfide gas.

\subsection{Project Objective}

1) This project has two objectives. The first is to explore sulfide in the oil and associated water and look for evidence of sulfur reduction by microbial activity. The second goal is to narrow down the possible causes of this sulfide gas.

\subsection{Project Organization}

Dr. Victor Medina - Project Lead

Michelle Wynter - Quality Assurance Plan, filter study, data analysis

Dr. Cari Jung - Genetic studies for Sulfate Reducing Bacteria

Amber Russell - Coordination with contract laboratories, analysis of water samples

\section{SECTION 2.0 SAMPLING / MONITORING PROCEDURES}

We will study samples from 3 dams (Blue River, Cougar and Hills Creek) that have had reported hydrogen sulfide issues. The total number of samples are estimated at 18 hydraulic oil samples and 3 water samples. ERDC will also receive filter samples. 


\section{SECTION 3.0 TESTING AND MEASUREMENT PROTOCOLS}

\subsection{Measurements to be conducted by ERDC}

ERDC will conduct the following measurements using the following methods:

- Survey Hydraulic oil samples and water samples for the presence and activity of dissimilatory sulfate reduction. A PCR-based survey targeting the conserved dissimilatory sulfate reduction (DSR) gene was employed. The presence of this gene would indicate at a genetic level the physiological potential of sponsor-selected samples toward the reduction of sulfate and the presence of sulfate reducing bacteria (SRBs) that may be responsible for biofouling.

- The hydraulic filters and scrapings from filters using binocular microscope. Interesting portions will also be investigated via scanning electron microscopy.

3.2 Other analyses were conducted by a certified commercial laboratory.

Conductivity, $\mathrm{pH}$, total sulfur, sulfide, sulfate, and zinc analyses were conducted for the water samples. The oil samples were analyzed for water content, zinc, sulfur, acid number, and sulfur reducing microorganisms using a genetic probe.

\section{SECTION 4.0 DATA REPORTING}

\subsection{Literature study}

A Literature search will be completed on most likely ways that $\mathrm{H} 2 \mathrm{~S}$ was produced under in-service conditions at Blue River, Cougar, and Hills Creek Dam for lubricant used.

\subsection{Report}

ERDC will prepare a report on its methods and findings. The ERDC reporting effort could be integrated into a larger report, if that is desirable. 


\section{Appendix D: Report on Sulfur Reducing Microbial Probe Investigation}


FINAL REPORT

Survey of sulfate reducing bacteria in hydraulic oils and water samples from USACE Portland.

Carina M. Jung

U.S. Army Engineer Research and Development Center

Environmental Laboratory

3909 Halls Ferry Road

Vicksburg, Mississippi 39180-6199

Phone: 601 634-7247

Email: carina.m.jung@usace.army.mil 
Purpose. Survey Hydraulic oil samples and water samples sent from the USACE Portland district for the presence and activity of dissimilatory sulfate reduction.

Materials and Methods. A PCR-based survey targeting the conserved dissimilatory sulfate reduction (DSR) gene was employed. The presence of this gene would indicate at a genetic level the physiological potential of sponsor-selected samples toward the reduction of sulfate and the presence of sulfate reducing bacteria (SRBs) that may be responsible for biofouling. A physiological diagnostic test known colloquially as a BART test was also performed on 18 select samples.

Aliquots were taken from the samples and poured into into a $50 \mathrm{ml} \mathrm{Falcon} \mathrm{tube.} \mathrm{The}$ samples were further split by placing $15 \mathrm{ml}$ into a BART test vial for SRBs (http://www.hach.com/bart-test-sulfate-reducing-bacteria-pk-9/productdownloads?id=7640250866) and the remaining $30 \mathrm{ml}$ were centrifuged to separate the debris/cells from each water/oil sample. Sample \#25 had less volume than the other samples and we received only $30 \mathrm{ml}$ once the other groups took their portions. Also the filter samples (\#21-24) were obtained by dissecting the apparatus and taking the two innermost layers from each. A portion of the filter material was cut away and $0.25 \mathrm{~g}$ was added to the DNA extraction kit as detailed for the remaining samples below. The debris/cells from liquid samples were washed with sterile water and centrifuged again. The cleaned debris/cells were extracted with a MoBio Power Soil DNA extraction kit following the manufacturer's instructions. Samples were processed by standard DNA extraction techniques and traditional PCR was performed. Each sample was PCR amplified with $16 \mathrm{~S}$ rDNA primers (Table 1) as a quality control check for amplification of the isolated DNA; this targets ribosomal DNA and is always present if bacteria are present; a negative reaction means the sample has extremely low or absent biomass. DNA samples were then amplified with the DSR primer sets specific for SRBs (Table 1).

Table 1. Primers and conditions for targeted PCR.

\begin{tabular}{|c|c|c|c|}
\hline Primer & Primers $\left(5^{\prime}-3^{\prime}\right)$ & PCR parameters & Reference \\
\hline$d s r 1$ & $\begin{array}{l}\text { F - ACSCACTGGAAGCACG } \\
\text { R - GTGGAGCCGTGCATGTT }\end{array}$ & $\begin{array}{l}95^{\circ} \mathrm{C} \text { for } 10 \mathrm{~min}, 40 \text { cycles of } 15 \\
\mathrm{~s} \mathrm{at} 94^{\circ} \mathrm{C}, 1 \mathrm{~min} \text { at } 59^{\circ} \mathrm{C}, 45 \mathrm{~s} \\
\text { at } 72^{\circ} \mathrm{C}\end{array}$ & Leloup 2007 \\
\hline 16S rRNA & $\begin{array}{l}\text { F - AGAGTTTGATCATGGCTCAG } \\
\text { R -TACGGYTACCTTGTTACGACTT }\end{array}$ & $\begin{array}{l}95^{\circ} \mathrm{C} \text { for } 5 \mathrm{~min} ; 32 \text { cycles of } \\
94^{\circ} \mathrm{C} \text { for } 45 \mathrm{~s} 55^{\circ} \mathrm{C} \text { for } 45 \mathrm{~s} \text { and } \\
72^{\circ} \mathrm{C} \text { for } 1 \mathrm{~min} ; \text { and a final } \\
\text { extension of } 72^{\circ} \mathrm{C} \text { for } 10 \mathrm{~min}\end{array}$ & $\begin{array}{l}\text { Krause } \\
2000\end{array}$ \\
\hline
\end{tabular}


Each of the 11 samples successfully amplified (Figure 2). DNA samples were then amplified with the primer sets specific for three gene targets (Table 1).

Results and Discussion. Samples were PCR amplified with primers for a ribosomal gene present in all bacteria as a control to determine the ability of the samples to be amplified by DNA and/or as an assessment of the presence or absence of bacteria. Only 10 samples appeared to be either capable of amplification or contain bacteria. Nevertheless, all samples were then PCR amplified for the dissimilatory sulfate reduction pathway, dsr1. There was no visual amplification of any of the samples with the DSR primers. In light of the $16 \mathrm{~S}$ rDNA PCR results only those sample results that were positive for $16 \mathrm{~S}$ can be trusted to be amplified and to have bacteria present. However, all of the samples were negative for the presence of the DSR gene and there may be either no or very limited numbers of SRBs in the source site.

As a further test for the presence of SRBs and bacteria in general, a physiological assessment of the samples was conducted on select samples. Samples were inoculated into a BART test which is used routinely in field testing for the presence of SRBs in water, soils, and industrial oils. All tested samples confirmed the results of PCR and were negative for SRB activity after 9 days. Furthermore, there was no evidence of anaerobic bacterial activity.

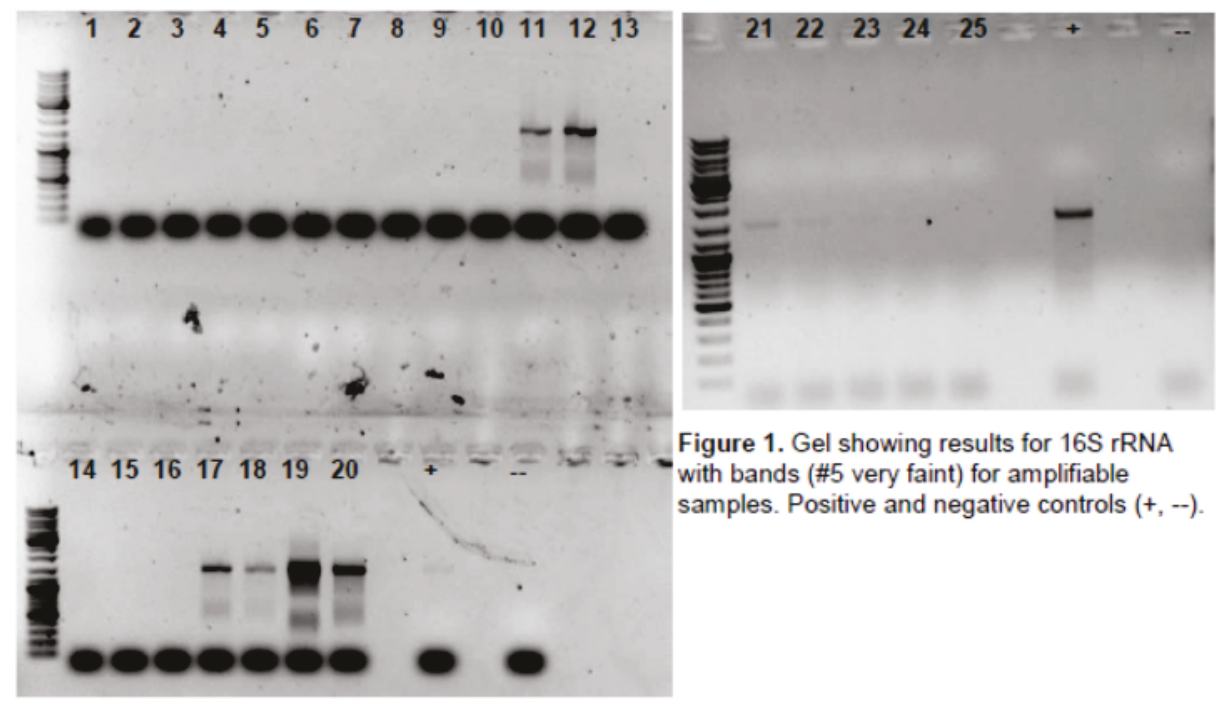


DSR Portland Final Report Jung- February 14, 2017

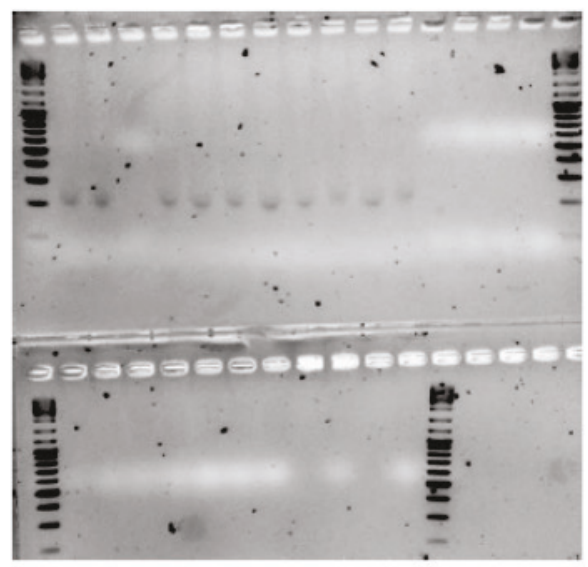

Figure 2. Gel showing negative results for DSR gene. Band should be located at the $3^{\text {rd }}$ band from the bottom, above the faint bands that are seen in the first lanes.

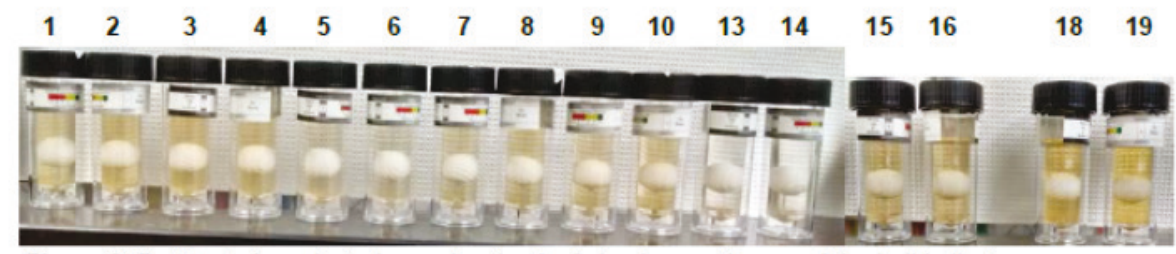

Figure 3. Bart tests for selected samples. Lack of cloudy growth around the ball indicates no or inconsequential numbers of anaerobic bacteria present. The lack of black precipitate indicates no sulfate reduction was occurring. The test spanned nine days and was observed daily. 
Table 2. Summary of samples processed, biological tests run, and results

\begin{tabular}{|c|c|c|c|c|c|c|c|c|}
\hline \multirow{2}{*}{$\begin{array}{c}\text { sample \# } \\
1\end{array}$} & \multicolumn{5}{|c|}{ Blue River Dam } & \multirow{2}{*}{$\begin{array}{c}165 \text { PCR } \\
-\end{array}$} & \multirow{2}{*}{$\begin{array}{c}\text { DSR } \\
\text { PCR } \\
-\end{array}$} & \multirow{2}{*}{$\begin{array}{r}\text { BART } \\
-\end{array}$} \\
\hline & BLR-20170126-001 & $10 / 18 / 2016$ & Grab & Hydraulic Oil & Orieinal Oil Sample & & & \\
\hline 2 & BLR-20170126-002 & $1 / 26 / 2017$ & Grab & Hydraulic Oil & $\begin{array}{l}\text { HPU oil sumo tank samole } \\
\text { oort }\end{array}$ & - & - & - \\
\hline 3 & BLR-20170126-003 & $1 / 26 / 2017$ & Grab & Hydraulic Oil & HPU oil sumo tank drain oort & - & - & -- \\
\hline 25 & BLR-20170126-004 & $1 / 26 / 2017$ & Grab & Hydraulic Oil & RO $n 1$ Service Top & & - & NA \\
\hline 4 & BLR-20170126-005 & $1 / 26 / 2017$ & Grab & Hydraulic Oil & RO $\# 1$ Service Bottom & - & - & - \\
\hline 5 & BLR-20170126-006 & $1 / 26 / 2017$ & Grab & Hydraulic Oil & RO $\approx 1$ Emerency Top & + & - & - \\
\hline 6 & BLR-20170126-007 & $1 / 26 / 2017$ & Grab & Hydraulic Oil & RO $\approx 1$ Emergency Bottom & - & - & - \\
\hline 7 & BLR-20170126-008 & $1 / 26 / 2017$ & Grab & Hydraulic Oil & RO $\approx 2$ Service Too & - & - & -- \\
\hline 8 & BLR-20170126-009 & $1 / 26 / 2017$ & Grab & Hydraulic Oil & $R O=2$ Service Bottom & - & - & -- \\
\hline 9 & BLR-20170126-010 & $1 / 26 / 2017$ & Grab & Hydraulic Oil & RO $\approx 2$ Emergency Too & - & - & - \\
\hline 10 & BLR-20170126-011 & $1 / 26 / 2017$ & Grab & Hydraulic Oi & RO $\equiv 2$ Emergency Bottom & - & - & - \\
\hline 11 & BLR-20170126-012 & $1 / 26 / 2017$ & Grab & Water & Drainage Sumo & + & - & NA \\
\hline 12 & BLR-20170126-013 & $1 / 26 / 2017$ & Grab & Water & Reservoir near intake tower & + & - & NA \\
\hline 21 & BLR-20170126-014 & $10 / 18 / 2016$ & inner layer (4) & $\begin{array}{l}\text { Filter } \\
\text { Cartridge }\end{array}$ & Original Oil Filter & + & - & NA \\
\hline 22 & BLR-20170126-014 & $10 / 18 / 2016$ & innermost layer (5) & $\begin{array}{l}\text { Filter } \\
\text { Cartridge }\end{array}$ & Original Oil Filter & + & - & NA \\
\hline 23 & BLR-20170126-015 & $10 / 18 / 2016$ & inner layer (4) & $\begin{array}{l}\text { Filter } \\
\text { Cartridge }\end{array}$ & Original Oil Filter & + & - & NA \\
\hline 24 & BLR-20170126-015 & $10 / 18 / 2016$ & innermost layer (5) & $\begin{array}{l}\text { Filter } \\
\text { Cartridge }\end{array}$ & Original Oil Filter & - & - & NA \\
\hline 13 & BLR-20170126-016 & $1 / 26 / 2017$ & Grab & Hydraulic Oil & $\begin{array}{l}\text { Chevron Rando HD ISO } 32 \\
\text { NEW oil }\end{array}$ & - & - & - \\
\hline 14 & BLR-20170126-017 & $1 / 26 / 2017$ & Grab & Hydraulic Oil & $\begin{array}{l}\text { Chevron Rando HD ISO } 32 \\
\text { NEW oil }\end{array}$ & - & - & - \\
\hline \multicolumn{9}{|c|}{ Cougar Dam } \\
\hline 15 & $\begin{array}{l}\text { CGR-20170126- } \\
001\end{array}$ & $1 / 26 / 2017$ & Grab & & $\begin{array}{l}\text { HPU oil sumo tank samole } \\
\text { oort }\end{array}$ & - & - & - \\
\hline
\end{tabular}

DSR Portland Final Report Jung- February 14, 2017

\begin{tabular}{|c|c|c|c|c|c|c|c|}
\hline 16 & $\begin{array}{l}\text { CGR-20170126- } \\
002\end{array}$ & $1 / 26 / 2017$ & Grab & HPU oil sumo tank drain oort & - & - & -- \\
\hline 17 & $\begin{array}{l}\text { CGR-20170126- } \\
003\end{array}$ & $1 / 26 / 2017$ & Grab & Reservoir near intake tower & + & - & NA \\
\hline \multicolumn{8}{|c|}{ Hills Creek Dam } \\
\hline 18 & $\begin{array}{l}\text { HCR-20170126- } \\
001\end{array}$ & $1 / 26 / 2017$ & Grab & $\begin{array}{l}\text { HPU oil sumo tank sample } \\
\text { port }\end{array}$ & + & - & - \\
\hline 19 & $\begin{array}{l}\text { HCR-20170126- } \\
002\end{array}$ & $1 / 26 / 2017$ & Grab & HPU oil sumo tank drain oort & + & - & - \\
\hline 20 & $\begin{array}{l}\text { HCR-20170126- } \\
003\end{array}$ & $1 / 26 / 2017$ & Grab & Reservoir near intake tower & + & - & NA \\
\hline
\end{tabular}

\section{References.}

Krause, D.O., W.J. Smith, F.M. Ryan, R.I. Mackie, C.S. McSweeney. 1999. Use of 16S-rRNA based techniques to investigate the ecological succession of microbial populations in the immature lamb rumen: tracking of a specific strain of inoculated Ruminococcus and interactions with other microbial populations in vivo. Micob. Ecol. 38(4):365-376.

Leloup,J., A. Loy, N.J. Knab, C. Borowski, M. Wagner and B.B. Jergensen. 2007. Diversity and abundance of sulfatereducing microorganisms in the sulfate and methane zones of a marine sediment, Black Sea. Environ. Microbiol 9(1):131-142 


\section{Appendix E: Product Data Sheet (PDS) for Chevron AW Oil - Alternative to Rando Oil}




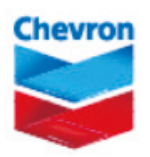

\section{Chevron Hydraulic Oil AW $32,46,68$ \& ISOCLEAN ${ }^{\circledR}$ Certified}

\section{PRODUCT DESCRIPTION \\ Chevron Hydraulic Oils AW are designed to give excellent hydraulic pump protection. Chevron Hydraulic Oils AW are available as ISOCLEAN ${ }^{3}$ Certified \\ Lubricants, which have been certified to meet specified ISO Cleanliness standards at point of delivery using industry leading filtration and testing technology. ISOCLEAN Certified products are the first step for contamination control and maximizing component life.}

\section{CUSTOMER BENEFITS}

Chevron Hydraulic Oils AW deliver value through:

- Good oxidation stability - Provide good service life in high pressure service.

- Rust and corrosion protection - Give excellent protection against corrosion of both copper and steel, and passes the ASTM D665A distilled water rust test and ASTM D665B synthetic sea water rust test.

- Minimum viscosity change over a wide temperature range.

- Good foam inhibition - Contain special foam suppressant, minimizing both foaming and aeration problems.

- Excellent antiwear properties

- Meets major pump manufacturer's requirements - ISO 32,46 and 68 meet the requirements of leading hydraulic pump manufacturers for antiwear-type hydraulic fluids in both vane- and piston-type pumps.

- Good stability in the presence of water by ASTM D2619 Hydrolytic Stability test and the Denison hybrid T6H20C Wet Pump test.

- Good thermal stability in the presence of copper and steel by the MAG Cincinnati Machine Thermal Stability, Procedure A, test.
- Fast water separation - Minimize rust problems by fast release of water.

\section{CUSTOMER BENEFITS} ISOCLEAN CERTIFIED

Chevron Hydraulic Oil AW ISOCLEAN Certified Lubricants deliver value through:

- Ready to use - Enables users to meet stringent original equipment manufacturers' cleanliness standards for fill lubricants.

- Flexibility - ISO Cleanliness targets can be customized to fit your business application needs.

- Peace of mind - Each delivery of Chevron ISOCLEAN Certified Lubricant includes an ISOCLEAN Certificate of Analysis.

- OE fluid cleanliness requirements Customized to meet specific equipment manufacturers' fluid cleanliness requirements.

\section{FEATURES}

Chevron Hydraulic Oils AW are formulated with refined paraffinic base oils. They provide excellent antiwear protection, oxidation and corrosion inhibition, as well as foam and aeration suppression. All grades have excellent demulsibility characteristics.

Hydraulic systems, due to the nature of their operation, experience accelerated wear unless they are protected by clean, high quality antiwear hydraulic oils. Surging pressures in pumps and valves can increase metal-to-metal contact unless antiwear protection is present. The antiwear additives in Chevron Hydraulic Oils AW create a protective film on the metal surfaces. This protective film minimizes metal-to-metal contact, which is most severe in vane- and gear-type pumps. As hydraulic pressures increase over 1000 psi, the need for antiwear protection increases proportionally.

Product(s) manufactured in the USA.

Always confirm that the product selected is consistent with the original equipment manufacturer's recommendation for the equipment operating conditions and customer's maintenance practices.

A Chevron company product

C 2008-2016 Chevron U.S.A. Inc. All rights reserved.

Chevron, the Chevron Hallmark and ISOCLEAN are trademarks owned by Chevron Intellectual Property LLC. All other trademarks are property of their respective owners. 
Chevron Hydraulic Oil AW - Continued

\section{APPLICATIONS}

Chevron Hydraulic Oils AW are versatile lubricants available in ISO viscosity grades 32,46 and 68 .

ISO 32, 46 and 68 grades are most commonly used for hydraulics with vane-, piston-, or gear-type pumps, especially where pressures exceed 1000 psi. They can also be used to lubricate lightly loaded reciprocating compressors.

Chevron Hydraulic Oils AW 32, 46 and 68:

- meet major pump manufacturer requirements including Eaton-Vickers 35VQ25A for M-2950-S

(Mobile) and I-286-S (Stationary), Parker

Hannifin (Denison) HFO/HF2/T6H2OC, and

Bosch Rexroth Racine Model S

- meet ASTM D6158 HM

- meet DIN 51524-2

- meet ISO 11158 L-HM
- meet MAG Cincinnati, Cincinnati Machine specifications P-68 (ISO 32), P-70 (ISO 46), and P-69 (ISO 68)

Chevron Hydraulic Oils AW 32, 46, 68 and ISOCLEAN ${ }^{3}$ Certified 32, 46, 68 are registered by NSF and are acceptable as lubricants where there is no possibility of food contact $(\mathrm{H} 2)$ in and around food processing areas. The NSF Nonfood Compounds Registration Program is a continuation of the USDA product approval and listing program, which is based on meeting regulatory

requirements of appropriate use, ingredient review and labeling verification.

Please consult with your equipment manufacturer if equipment is operating outside normal operating conditions. Do not use in high pressure systems in the vicinity of flames, sparks and hot surfaces. Use only in well ventilated areas. Keep container closed.

Consult with your Chevron Lubricant Representative or Chevron ISOCLEAN Certified Lubricants Marketer to set specific ISO Cleanliness targets for your business application.

\section{Typical TEST DATA}

\begin{tabular}{|l|c|c|c|}
\hline ISO Grade & 32 & 46 & 68 \\
\hline \hline Product Number & 255675 & 255674 & 255673 \\
\hline $\begin{array}{l}\text { Product Number } \\
\text { ISOCLEAN Certified }\end{array}$ & 293130 & 293131 & 293132 \\
\hline SDS Number & 7457 & 7457 & 7457 \\
\hline API Gravity & 32.6 & 31.8 & 31.6 \\
\hline $\begin{array}{l}\text { Viscosity, Kinematic } \\
\text { cSt at } 40^{\circ} \mathrm{C} \\
\text { cSt at } 100^{\circ} \mathrm{C}\end{array}$ & 30.4 & 43.7 & 64.6 \\
\hline $\begin{array}{l}\text { Viscosity, Saybolt } \\
\text { SUS at } 100^{\circ} \mathrm{F} \\
\text { SUS at } 210^{\circ} \mathrm{F}\end{array}$ & 5.2 & 6.5 & 8.4 \\
\hline Viscosity Index & 157 & 225 & 334 \\
\hline Flash Point, ${ }^{\circ} \mathrm{C}\left({ }^{\circ} \mathrm{F}\right)$ & 44 & 48 & 55 \\
\hline Pour Point, ${ }^{\circ} \mathrm{C}\left({ }^{\circ} \mathrm{F}\right)$ & $220(428)$ & $226(439)$ & $235(455)$ \\
\hline $\begin{array}{l}\text { Oxidation Stability } \\
\text { Hours to } 2.0^{\circ} \mathrm{mg} \text { KOH/g acid number, ASTM D943 }\end{array}$ & $-25(-13)$ & $-23(-9)$ & $-22(-8)$ \\
\hline
\end{tabular}

Minor variations in product typical test data are to be expected in normal manufacturing.

Always confirm that the product selected is consistent with the original equipment manufacturer's recommendation for the equipment operating conditions and customer's maintenance practices. 


\section{REPORT DOCUMENTATION PAGE}

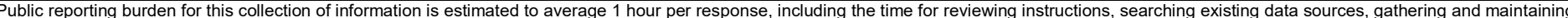

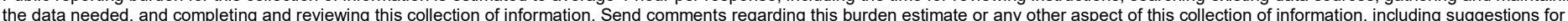

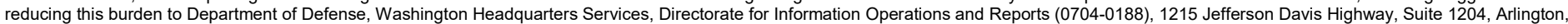

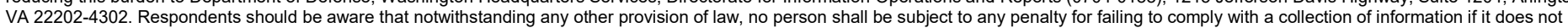
display a currently valid OMB control number. PLEASE DO NOT RETURN YOUR FORM TO THE ABOVE ADDRESS.
1. REPORT DATE (DD-MM-YYYY) 2. REPORT TYPE
3. DATES COVERED (From - To)

April 2018 Final report

\section{TITLE AND SUBTITLE}

Evaluation of Sulfide Emissions from a Hydraulic System at the Blue River Dam

5a. CONTRACT NUMBER

5b. GRANT NUMBER

5c. PROGRAM ELEMENT NUMBER

\section{AUTHOR(S)}

Victor F. Medina, Michelle Wynter, Carina Jung, Amber Russell, Timothy Paulus, and Chris S. Griggs

\section{PERFORMING ORGANIZATION NAME(S) AND ADDRESS(ES)}

U.S. Army Engineer Research and Development Center, Environmental Laboratory 3909 Halls Ferry Road, Vicksburg, MS 39180-6199

\section{SPONSORING / MONITORING AGENCY NAME(S) AND ADDRESS(ES)}

Headquarters, Portland District (NWP)

333 SW 1st Ave, Portland, OR 97204

5d. PROJECT NUMBER

5e. TASK NUMBER

5f. WORK UNIT NUMBER

33143

8. PERFORMING ORGANIZATION REPORT NUMBER

ERDC/EL TR-18-5

10. SPONSOR/MONITOR'S ACRONYM(S)

NWP

11. SPONSOR/MONITOR'S REPORT NUMBER(S)

\section{DISTRIBUTION / AVAILABILITY STATEMENT}

Approved for public release; distribution unlimited.

\section{SUPPLEMENTARY NOTES}

\section{ABSTRACT}

Hydrogen sulfide releases occurred during a routine maintenance process in a hydraulic oil system at Blue River Dam, Oregon. The project worked under the hypothesis that the sulfide emissions most likely resulted from reductive biological processes. Hydraulic oil samples were collected from the Blue River Dam, and from two other nearby dams with similar hydraulic systems, Hills Creek Dam, and Cougar Dam. Water samples from the reservoir were also collected. Sulfur was found in all the oil and water samples, however, no patterns with sulfur to other parameters (such as percent water or acid neutralization number) were found in the oil samples. A microscopic review of hydraulic filters did not show any evidence of bio-film accumulation. The use of sulfate reductive bacterial genetic probes did not find any microbial activity expected to form sulfide. These results rejected the hypothesis that the sulfide production was from microbial activity. The Authors now hypothesize that the sulfide reaction was from abiotic reactions of an additive, Zinc Dialkyldithiophosphate (ZDDP).

\section{SUBJECT TERMS}

Blue River Dam (Or.)

Hydraulic structures
Water quality

Hydrogen sulfide

\section{SECURITY CLASSIFICATION OF:}

\begin{tabular}{l|l}
\hline a. REPORT & b. ABSTRACT \\
UNCLASSIFIED & UNCLASSIFIED \\
\hline
\end{tabular}

17. LIMITATION
OF ABSTRACT

\begin{tabular}{l|l} 
18. NUMBER \\
OF PAGES \\
\cline { 2 - 2 }
\end{tabular}

19a. NAME OF RESPONSIBLE PERSON

19b. TELEPHONE NUMBER (include area code) 